\title{
Neogene Tectonics and Geomorphology of the Eastern Uinta Mountains in Utah, Colorado, and Wyoming
}

U.S. GEOLOGICAL SURVEY PROFESSIONAL PAPER 1356

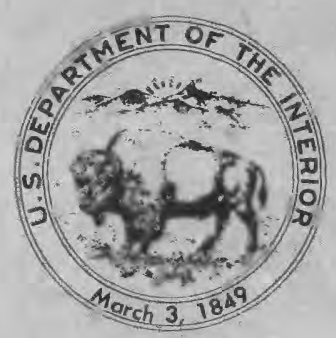


NEOGENE TECTONICS AND GEOMORPHOLOGY OF THE EASTERN UINTA MOUNTAINS IN UTAH, COLORADO, AND WYOMING 


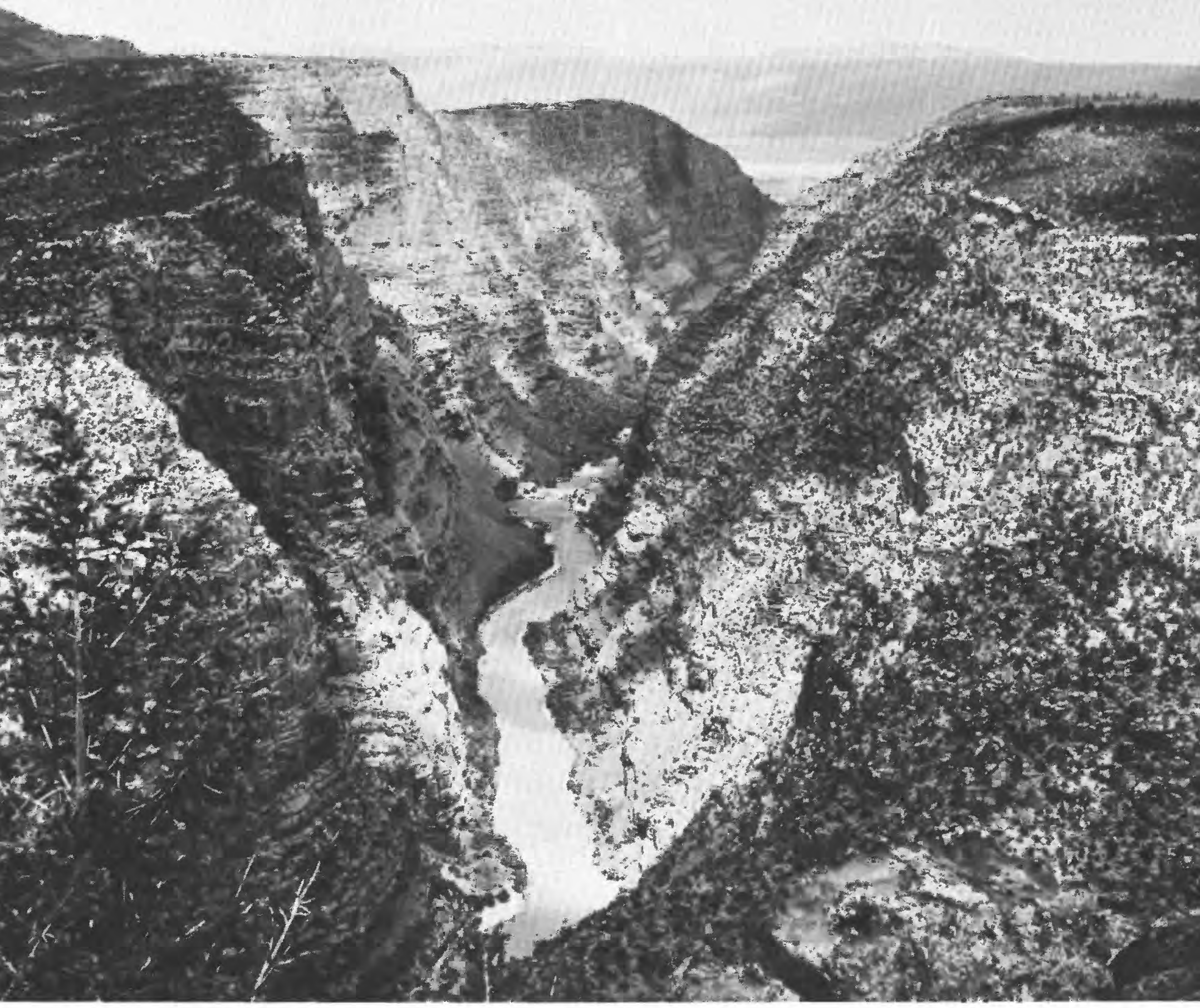

FRONTISPIECE.-View north up Lodore Canyon toward Browns Park from rim of Douglas Mountain, showing downward steepening of the cross-canyon profile $245-300 \mathrm{~m}$ above river level, presumably caused by Pleistocene reentrenchment of the Green River. Canyon here is about $700 \mathrm{~m}$ deep. Even-topped Cold Spring Mountain is on distant skyline, below Diamond Peak at upper right. 


\section{Neogene Tectonics and Geomorphology of the Eastern Uinta Mountains in Utah, Colorado, and Wyoming}

By WALLACE R. HANSEN

U.S. GEOLOGICAL SURVEY PROFESSIONAL PAPER 1356

The relationship of a widespread erosion surface and its capping of conglomerate to the subsequent structural and drainage history of a classic region

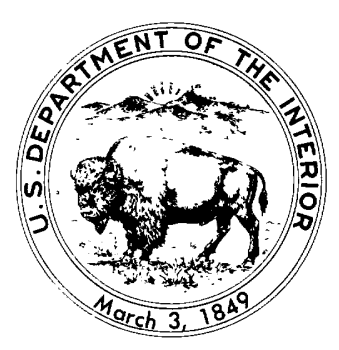




\section{DEPARTMENT OF THE INTERIOR}

DONALD PAUL HODEL, Secretary

\section{U.S. GEOLOGICAL SURVEY}

Dallas L. Peck, Director

Library of Congress Cataloging in Publication Data

Hansen, Wallace R., 1920-

Neogene tectonics and geomorphology of the eastern Uinta Mountains in Utah, Colorado, and Wyoming.

(Geological Survey professional paper ; 1356)

Bibliography: $\mathrm{p}$.

Supt. of Docs. No.: I 19.16:1356

1. Geology, Stratigraphic-Tertiary. 2. Geology-Uinta Mountains Region (Utah and Wyo.) 3. GeologyColorado. 4. Geomorphology-Uinta Mountains Region (Utah and Wyo.) 5. Geomorphology-Colorado. I. Title. II. Series.

QE691.H36 1986

$551.7^{\prime} 86$

$85-600166$

For sale by the Branch of Distribution Books and Open-File Reports Section

U.S. Geological Survey

Federal Center

Box 25425

Denver, CO 80225 


\section{CONTENTS}

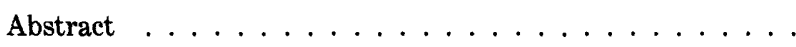

Introduction ...................

Regional setting ................

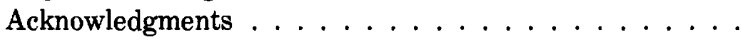

Gilbert Peak erosion surface ...............

Extent in the Eastern Uinta Mountains .........

Wild Mountain upland surface .............

Bishop Conglomerate .................

General features and distribution ............

Lithology and thickness ...............

Sandstone .................



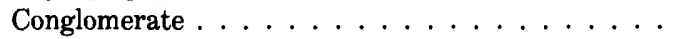

Altitude and relief ...............

Rates of uplift ...............

Browns Park Formation .................. 28

Post-Bishop, pre-Browns Park change in drainage direction 29

Age of the Browns Park Formation .........

Bishop Conglomerate beneath the Browns Park Formation.

Critical relationship of the Browns Park Formation to the

Bishop Conglomerate near Lily Park...........

Random relationship of the Browns Park Formation to the Gilbert Peak erosion surface.............
Physical geography at the onset of deposition of the Bishop

\begin{tabular}{|c|c|c|}
\hline age & & Page \\
\hline 1 & $\ldots \ldots \ldots \ldots \ldots \ldots$ & 39 \\
\hline 2 & North flank . . . . . . . . . . . . . & 41 \\
\hline 2 & South flank & 45 \\
\hline 8 & Nonuniform tilting on the south flank . . . . . . & 40 \\
\hline 8 & West-to-east tilting on the south flank . . . . . & 47 \\
\hline 12 & Cliff Ridge area . . . . . . . . . . . & 47 \\
\hline 14 & Mud Springs Draw and Wolf Creek ...... & 47 \\
\hline & $\ldots \ldots \ldots$ & 48 \\
\hline & least end of the range. & bu \\
\hline & lary of post-Browns Park deformation ...... & 51 \\
\hline 2] & Diamond Peak and Browns Park ........ & 51 \\
\hline & 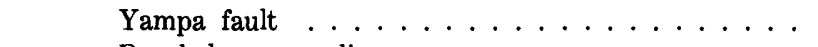 & 51 \\
\hline 23 & Deerlodge monocline . . . . . . . . . . & 53 \\
\hline & 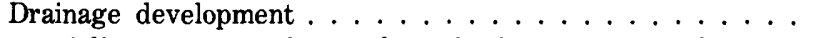 & 53 \\
\hline 24 & justments on the south flank-in the Pot Creek area. & 54 \\
\hline 27 & nents on Blue Mountain ............ & 55 \\
\hline 27 & le north flank . . . . . . . . & 57 \\
\hline 28 & area . . . . . . . . . & 57 \\
\hline 29 & d Irish Canyon . : & 60 \\
\hline 31 & and development of Lodore Canyon. & 62 \\
\hline & $\ldots \ldots \ldots$ & 64 \\
\hline & & \\
\hline 32 & of capture to fish faunas & 70 \\
\hline & $\begin{array}{c}\text { een River } \ldots \ldots \\
\ldots \ldots\end{array}$ & \\
\hline
\end{tabular}

\section{ILLUSTRATIONS}

Frontispiece. View north up Lodore Canyon toward Browns Park.

FIGURES 1-5. Maps showing:

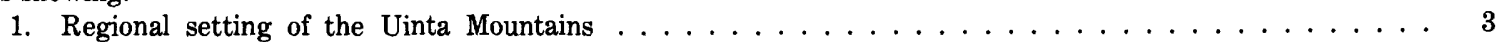



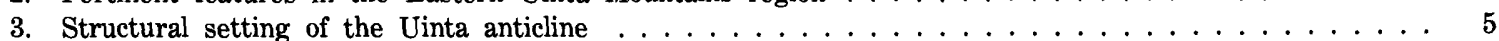

4. Generalized structure of the Uinta Mountains . . . . . . . . . . . . . . . . . 6

5. Distribution of Browns Park Formation, Bishop Conglomerate, and Gilbert Peak erosion surface . . . 7

6. Photographs depicting character and extent of Gilbert Peak erosion surface . . . . . . . . . . . . 9

7. Composite profile of erosion remnants between Gilbert Peak and Green River airport . . . . . . . . . . . . 10

8-12. Photographs showing:

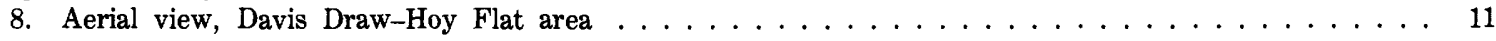

9. Remnants of the Gilbert Peak erosion surface in the easternmost Uinta Mountains . . . . . . . . . . . 13

10. Gilbert Peak erosion surface forming east rim of Lodore Canyon . . . . . . . . . . . . . . . . . . 14

11. Wild Mountain as seen from "Harpers Plateau" . . . . . . . . . . . . . . . . . . 15

12. Felsenmeer on the Madison Limestone, Douglas Mountain . . . . . . . . . . . . . . . . . . . . 16

13. Map showning generalized distribution of Bishop Conglomerate and Browns Park Formation in southeastern Uinta Mountains $\ldots \ldots \ldots \ldots \ldots \ldots \ldots \ldots \ldots$ 
FIGURES, 14-16. Photographs of the Bishop Conglomerate:

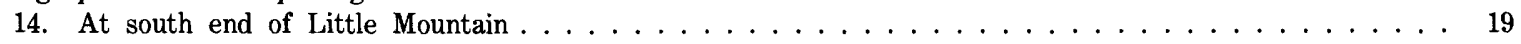

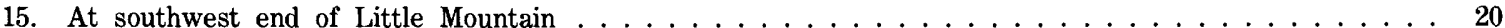

16. Coarsening-upward sequence at Sand Wash . . . . . . . . . . . . . . . . . . 21

17. Diagram showing directions of deltaic foreset bedding in the Laney Shale Member of the Green River Formation and transport directions of the Bishop Conglomerate $\ldots \ldots \ldots \ldots \ldots$

18-20. Photographs showing:



19. Water-laid tuffs in the Browns Park Formation . . . . . . . . . . . . . . . . . . . 30

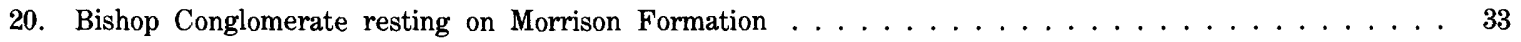

21. Sketch section showing relationship of Bishop Conglomerate to Browns Park Formation at canyon of Little Snake

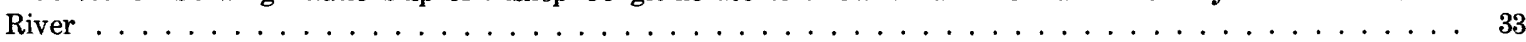

22. Photograph of basal conglomerate of Browns Park Formation resting on truncated Glen Canyon Sandstone . . . 34

23. Aerial photograph over Browns Park looking north across Cold Spring Mountain . . . . . . . . . . . . 36

24. Diagram showing how a fault that initially controlled drainage can shift away from drainage during degradation . 37

25. Generalized tectonic map of the Eastern Uinta Mountains . . . . . . . . . . . . . . . . . . 38

26. Cross section drawn to explain middle to late Tertiary deformation of the Gilbert Peak erosion surface . . . . 4 42

27. Map showing general extent of faults on north flank of Uinta Mountains between Flaming Gorge and Browns Park . 43

28. Cross section showing displacement of Gilbert Peak erosion surface in the Goslin Mountain area . . . . . . . 44

29. Geologic section showing northerly tilt of Gilbert Peak erosion surface on Blue Mountain . . . . . . . . . . 45

30. Structure map of base of Bishop Conglomerate showing post-Bishop warping and faulting of Gilbert Peak erosion surface, Diamond Mountain-Island Park-Blue Mountain area . . . . . . . . . . . . . . . 46

31. Profiles along both flanks of Uinta Mountains, showing eastward decline in altitude of Gilbert Peak erosion surface . 47

32. Photograph of Bishop-capped berm on the south flank of Stuntz Ridge . . . . . . . . . . . . . 48

33. Structure map of the Bishop Conglomerate in the Wolf Creek area . . . . . . . . . . . . . . . . 49

34. Photograph from rim of Johnson Draw west-northwest along the Yampa fault . . . . . . . . . . . . . 52

35-37. Maps showing:

35. Development of Green River from late Oligocene time to present . . . . . . . . . . . . . . . 54

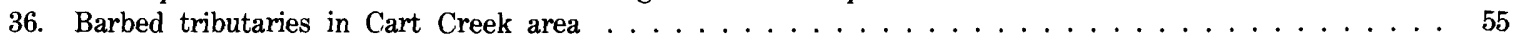

37. Distribution of Bishop Conglomerate in Pot Creek area . . . . . . . . . . . . . . 56

38. Diagram demonstrating effect of tilt on the low point of a concave-upward profile $\ldots \ldots \ldots$



40. Sketch map of hills, drainages, and tectonic features of northeast flank of Uinta Mountains . . . . . . . . 59

41. Diagram showing subsidence of Bear Mountain and reversal of gradient of Gilbert Peak erosion surface . . . 60

42. Geologic map of Vermillion Creek area affected by beheading of Irish Canyon . . . . . . . . . . . . . . . 61

43. Photograph of Klauson Pasture, showing terrace incised below Bishop Conglomerate . . . . . . . . . . 65

44. Photograph of Yampa River emerging from Cross Mountain Canyon . . . . . . . . . . . . . . . . 66

45. Geologic map and section showing large, retrogressive landslides in Yampa Canyon . . . . . . . . . . . 68

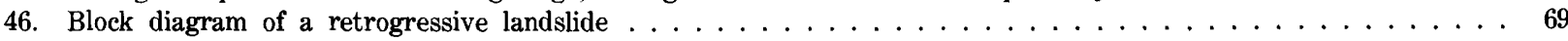

47. Photographs of Quaternary terraces in the Eastern Uinta Mountains area . . . . . . . . . . . . . . . 73

\section{TABLES}

TABLE 1. Distance from nearest possible sources of Bishop Conglomerate and maximum observed sizes of clasts $\ldots \ldots$

2. Summary of Tertiary and Quaternary tectonic, geomorphic, and sedimentologic events ............ $\ldots$ 


\title{
NEOGENE TECTONICS AND GEOMORPHOLOGY OF THE EASTERN UINTA MOUNTAINS IN UTAH, COLORADO, AND WYOMING
}

\author{
By Wallace R. HANSEN
}

ABSTRACT

A recent reevaluation of the Bishop Conglomerate in the Eastern Uinta Mountains region helps clarify how the conglomerate relates to the Browns Park Formation and, in turn, how both formations relate to middle Tertiary tectonic activity and late Tertiary and Quaternary drainage adjustments. Field relations indicate widely divergent histories for the two formations: They are separated in their type areas by great topographic discontinuity, but east of the Uinta Mountains, between Cross Mountain and Maybell, Colo., the Browns Park lies directly on the Bishop.

The Bishop Conglomerate is roughly coextensive with the subjacent Gilbert Peak erosion surface; the Bishop was deposited on this broad pediment soon after the surface formed, perhaps while the surface was still forming. In many places, however, mountainward parts of the surface are bare rock. These places and the adjacent mountains were the sources of the conglomerate. The site of Browns Park, which lies in the axial region of the Uinta anticline, was part of the crest of the Uinta Mountains when the Gilbert Peak surface was forming.

On the high proximal margins of the pediment, especially on the south slope of the range, headward parts of the surface penetrate deep into the range as flat-bottomed, alluviated remnants of dendritic valleys. Basinward, these valleys coalesced, and at one time they must have formed a continuous bajada around the north, east, and south margins of the range. A long period of crustal stability was needed to develop so broad and uniform a plain.

Nearly flat to rolling uplands $180 \mathrm{~m}$ or more above the Gilbert Peak surface and the Bishop Conglomerate at various places in the Eastern Uinta Mountains are regarded as remnants of a truncation surface higher and older than the Gilbert Peak surface. Remnants of this surface, here called the Wild Mountain upland surface, are preserved on Wild, Diamond, Douglas, Blue, and Cross Mountains and perhaps on summits farther west. They consist of resistant bare rock, and they truncate subjacent formations without regard for rock structure. The Wild Mountain upland surface probably is Eocene in age. It probably formed in the mountains while the thick Eocene alluvial and lacustrine deposits of the Wasatch, Green River, Bridger, and Uinta Formations were accumulating in the adjacent basins.

The Gilbert Peak erosion surface is regarded as Oligocene. Biotite and hornblende separates from tuffs high in the superjacent Bishop Conglomerate have recently been dated by the K-Ar method at 29 m.y. (Oligocene). These tuffs overlie most of the coarse conglomerate, but they are interbedded with and overlain by loose, poorly sorted pebbly sandstone that resembles some sandstone in the Browns Park Formation. This similarity has led to past correlations of Bishop with Browns Park in the Eastern Uinta Mountains. Some part of this sandstone sequence might be equivalent to the Browns Park Formation, but differing physical properties suggest that it is not.

With Laramide uplift of the Uinta Mountains, initial drainage was away from the mountains, and coarse orogenic deposits accumulated at the flanks. By middle Eocene time, however, during deposition of the Laney and Parachute Creek Members of the Green River Formation, a hydraulic connection probably existed between Lake Gosiute, on the north side of the range, and Lake Uinta, on the south side, as suggested by several workers, but the connection was blocked by the rise of the Axial Basin anticline at the end of Eocene time. The Gilbert Peak erosion surface was cut only after strong orogenic and epeirogenic uplift had warped the floors of the Tertiary basins enough to produce slope gradients sufficient to start erosion and pedimentation. From a late Eocene height of about $300 \mathrm{~m}$ above sea level, the basin floors rose to about $1,200 \mathrm{~m}$ by middle Oligocene time, at a rate of about $20 \mathrm{~cm}$ per thousand years. The mountains were perhaps $3,000-3,700 \mathrm{~m}$ above sea level. At that time, the Green River Basin probably had an outlet east toward the North Platte River.

Renewed deformation, beginning in late Oligocene time, terminated deposition of the Bishop Conglomerate and initiated far-reaching drainage changes. The south flank and the crest of the Eastern Uinta Mountains were tilted northward at a rate of about $28 \mathrm{~m} / \mathrm{km}$, lowering the crest about $1.6 \mathrm{~km}$ and reversing the directions of streams that formerly flowed south; the tilting also had an easterly component of about $9-11 \mathrm{~m} / \mathrm{km}$. The north flank was warped and tilted to varied attitudes, mainly by movements of blocks between the Uinta-Sparks fault zone and another fault zone along the north and northeast sides of Red Canyon and Browns Park. Much of this tilting was southward. The inward tilting of both flanks triggered eastward drainage through the Red Canyon-Browns Park area along the future course of the Green River. As a result of tilting and warping, the Gilbert Peak erosion surface was lowered 520-975 m on the north flank by gravitative movement along the Uinta fault. New tributary drainage on the north flank was directed south where previous drainage had flowed north.

Meanwhile, subsidence in the easternmost Uintas and the western part of Axial Basin lowered the Bishop Conglomerate sufficiently over wide areas to produce a topographic and structural trough in which the Browns Park Formation soon began to accumulate. In that area the Browns Park Formation was deposited directly on the subsided Bishop, but in other places, such as Red Canyon and Browns Park, it accumulated in canyons and valleys tens to hundreds of meters below nearby Gilbert Peak and Bishop remnants. Regionally, the Browns Park Formation thus has a random relationship to the Bishop Conglomerate. Deformation continued during and after the deposition of the Browns Park Formation, but at a reduced and diminishing rate. Most of the tributaries of the Green River downstream from Flaming Gorge were essentially in their present courses before the Browns Park Formation was deposited.

The Browns Park Formation continued to accumulate in Browns Park until the old valley was overtopped at the site of Lodore Canyon 
in late Miocene or early Pliocene time. This concept calls for a muchthickened Browns Park Formation, but the evidence seems irrefutable. Drainage that had flowed toward the downwarp at the east end of the Uintas now spilled south toward the Uinta Basin, eroding through the Bishop Conglomerate on the south flank of the range and superimposing itself into the underlying older rocks, where it ultimately cut its canyons. Because of the wide distribution of the Bishop on the rims of the canyons, there can be no doubt that the drainage was superimposed through it. Upstream, drainage reinvigorated by its diversion to a steeper course to the Uinta Basin, eroded rapidly downward and headward, eventually capturing all the runoff of the Green River Basin.

Drainage, meanwhile, was evolving in the Yampa River area. Like the course of the Green, the course of the Yampa in the Uinta Mountains is younger than the Bishop Conglomerate. Upstream from the Uinta Mountains, however, an ancestral Yampa River was transporting pebbly gravel from the Park Range into the Lay-Maybell area before the main body of the Browns Park Formation was deposited. This gravel is the true basal conglomerate of the Browns Park Formation, and it is younger than the Bishop Conglomerate. With the tectonic subsidence of the Eastern Uinta Mountains following deposition of the Bishop, the Lay-Maybell-Browns Park area became a stilling basin for the accumulation of the dominantly fine-grained lacustrine and eolian deposits of the Browns Park Formation. These deposits probably had varied sources, but much of the sand might have come from the Bishop, winnowed out by deflation. The abundant tuffs of the Browns Park Formation probably came from volcanic centers far to the west.

Drainage through the Yampa Canyon area must have existed when the basal conglomerate of the Browns Park Formation was accumulating, but the canyon at that time was shallow and juvenile. The canyon deepened later when runoff was reinvigorated; the time of this deepening can only be surmised, but downcutting and entrenchment would have been greatly enhanced by the spillover of the Green River into Lodore Canyon and the resultant rejuvenation of the drainage system. The present course of the Yampa through Cross Mountain Canyon and Juniper Canyon is an accident of superimposition following deposition of the Browns Park Formation, as first postulated by E. T. Hancock many years ago.

The most significant postulated drainage change in the Uinta region, in terms of the total budget of the streams involved, and probably also the most recent, was the diversion of the Upper Green River from an ancestral easterly course across the Rock Springs uplift in middle Pleistocene time. The river was flowing about $200 \mathrm{~m}$ above its present level at Green River, Wyo., at that time and only about $210 \mathrm{~m}$ lower than the present Continental Divide at Tipton, Wyo. Some post-diversion uplift of the Continental Divide, therefore, is required-warping up to the east at a rate of about $1.8 \mathrm{~m} / \mathrm{km}$, or about $3.1 \mathrm{~mm} / \mathrm{km} / 10^{3} \mathrm{yrs}$. Similarly, the Continental Divide at Tipton, since the postulated diversion, has risen at a rate of about $475 \mathrm{~mm} / 10^{3}$ yrs).

Canyon profiles in the Uinta Mountains indicate reentrenchment of the Green River since the initial cutting of its canyons. Downcutting had slowed, and the river had begun to widen the valley floor after Lodore Canyon was cut to a depth of about $460 \mathrm{~m}$. Rejuvenated, the river then cut an additional $245-300 \mathrm{~m}$ to its present level. Crosscanyon profiles now show a downward-steepening slope break about $245-300 \mathrm{~m}$ above the river. Regional uplift, perhaps in response to unloading, could have rejuvenated the entire drainage system through the mountains, or the capture of the Upper Green River in middle Pleistocene time could have caused reentrenchment by greatly increasing the discharge and competence of the system. Both uplift and capture may have been involved. Continued episodic downcutting and presumed uplift are indicated by Quaternary terraces.

\section{INTRODUCTION}

A recent reevaluation of the Bishop Conglomerate in the eastern part of the Uinta Mountains of Utah and Colorado helps clarify how the conglomerate relates to the Browns Park Formation and, in turn, how both formations relate to Tertiary tectonic activity and late Tertiary and Quaternary drainage adjustments. Field relations indicate divergent geomorphic histories for the two formations, yet over broad areas they are nearly coextensive and, as will be shown, the Browns Park locally rests directly on the Bishop. This latter relationship has led to the widely held but contentious belief that the Bishop is merely the basal conglomerate of the Browns Park Formation, a hypothesis first advanced by Sears (1924a, p. 289) but later vigorously disputed by his associate Bradley (1936, p. 182) and subsequently by others. Although Sears abandoned the idea, it has been revived in recent years, and it now appears that Sears was at least partly correct-correct in identifying as Bishop the thick conglomerate beneath much of the Browns Park Formation but incorrect in assigning it to the Browns Park. Some of the conglomerate beneath the Browns Park Formation surely is Bishop, but a hiatus is indicated between the two formations. Sears, moreover, showed that the Bishop is stratigraphically below the Browns Park and, hence, is older. The Browns Park is now well dated as largely Miocene; the Bishop is Oligocene. Earlier geologists had thought the Bishop to be the younger, and some of Sears' contemporaries had even believed that the Browns Park was a facies of the Eocene Bridger Formation, despite the fact that Powell $(1876$, p. 168) had described the unconformity between the Browns Park and the Bridger many years before. In their type areas the Bishop and the Browns Park are separated by great topographic discontinuity, the Bishop capping high mesas and the Browns Park filling deep adjacent valleys. Because of its wide geographic extent and relatively uniform character, the Bishop is an excellent datum for use in reconstructing tectonic and geomorphic events in the Uinta region.

\section{REGIONAL SETTING}

The area discussed in this report centers around the eastern part of the Uinta Mountains-here called simply "the Eastern Uinta Mountains"-and includes parts of the adjacent Tertiary basins in Utah, Colorado, and Wyoming (figs. 1 and 2). For a clear understanding of regional geographic relationships in this broad area, the 1:250,000-scale topographic maps of the Vernal and Rock Springs quadrangles are invaluable aids. These maps are culturally obsolescent, but they portray well 


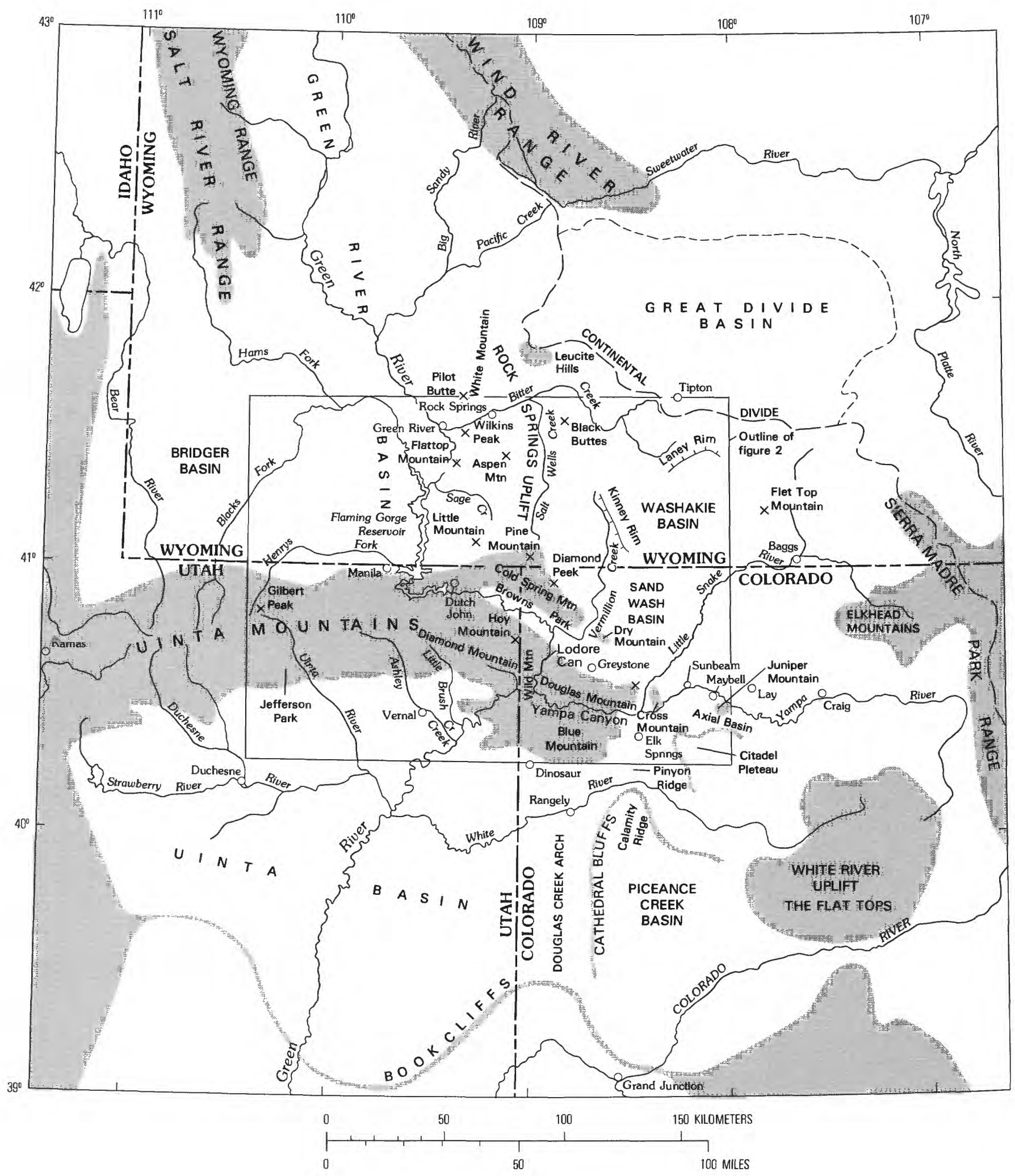

FIGURE 1.-Regional setting of the Uinta Mountains and principal rivers. Tint indicates mountainous areas. 


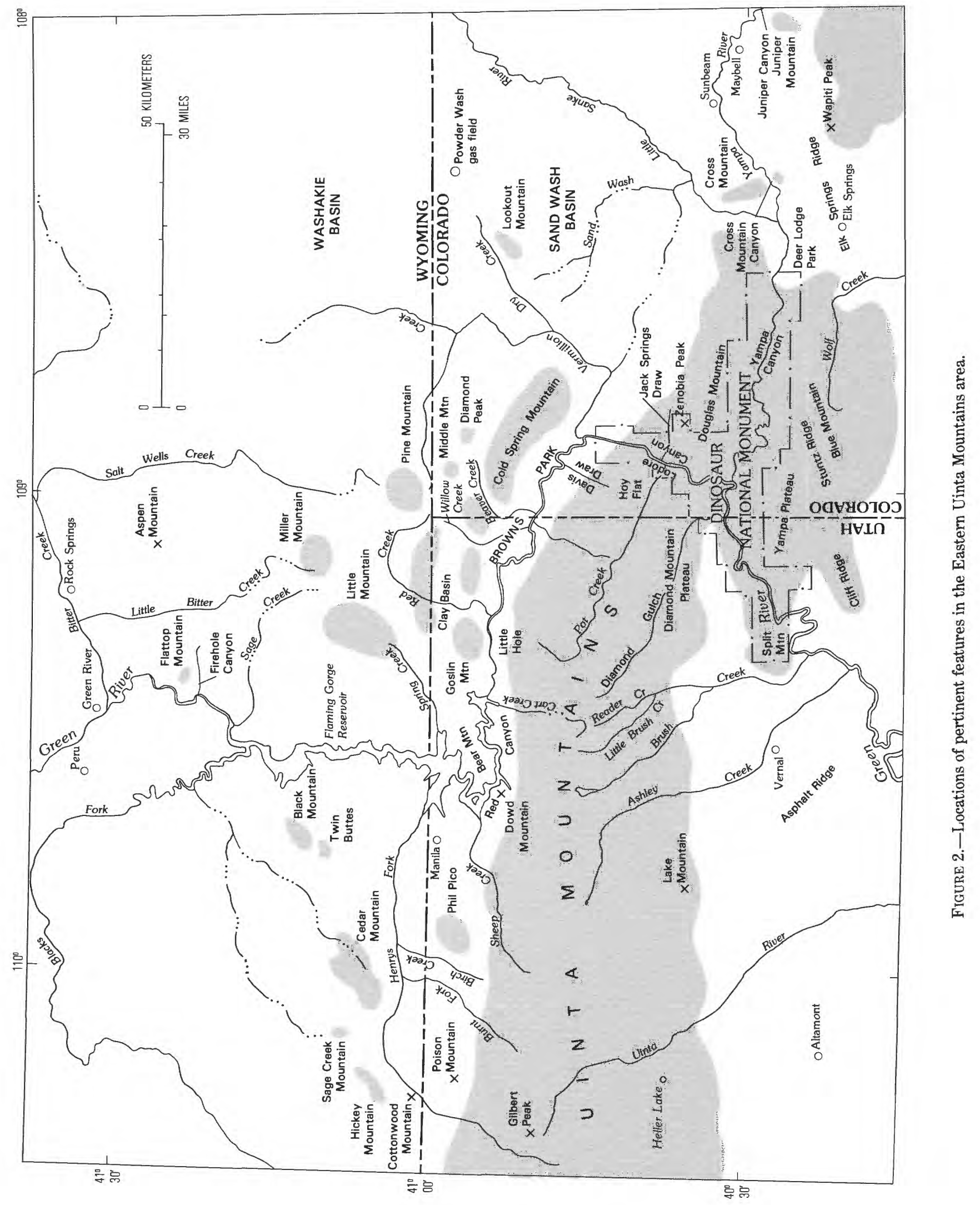




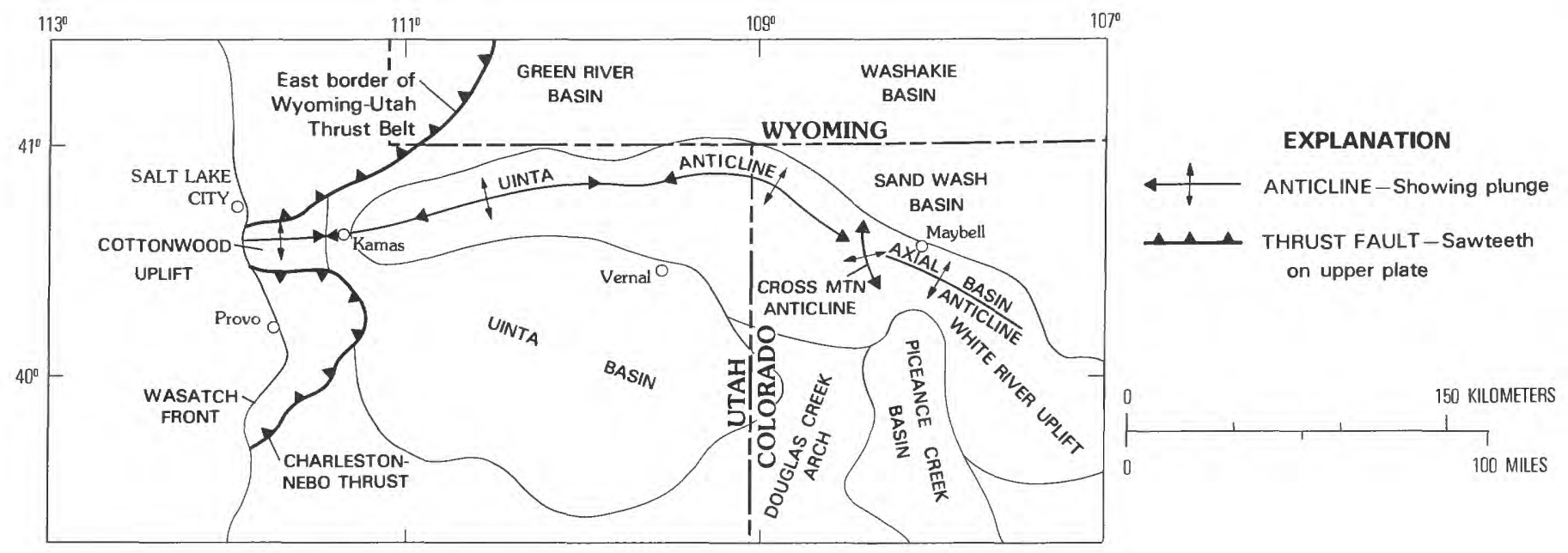

FIGURE 3.-Regional structural setting of the Uinta anticline.

most, of the larger scale topographic features. More detailed maps of local areas appear in the following text from place to place as needs arise.

The Uinta Mountains trend generally eastward from a junction with the Wasatch Range east of Salt Lake City. The crestline of the range is broadly arcuate, concave to the south; from the Wasatch Range junction it trends roughly N. $80^{\circ}$ E. for about $90 \mathrm{~km}$, then swings gradually around to about S. $60^{\circ} \mathrm{E}$. at the Colorado State line.

Structurally the range is a large compound anticline whose axis extends west beyond the Uinta Mountains through the Wasatch Range (Butler and others, 1920, p. 251; Billingsley, 1933, p. 19), emerging at the Wasatch Front as the axis of the Cottonwood uplift (Crittenden and others, 1952, 1973; Eardley, 1968). In the opposite direction the axis projects southeast toward the White River uplift in Colorado, merging into a plateau region of multiple but smaller folds (Tweto, 1976), a total axial length of at least $350 \mathrm{~km}$ (fig. 3).

Although the term Uinta arch, or even Uinta anticline, is sometimes applied to the Cottonwood uplift, a clear distinction should be drawn, as these features are structurally distinct, even though they are collinear. The Cottonwood uplift is a semicircular, eastplunging half dome, cored by Precambrian rocks and middle Tertiary intrusives, truncated on the west by the Wasatch fault, and separated from the Uinta anticline by a deep, north-trending synclinal valley partly filled with Tertiary volcanics (Boutwell, 1912, p. 43; Hintze, 1913, p. 130; Bromfield and others, 1977). The Uinta anticline proper is about $260 \mathrm{~km}$ long. Its west plunge at the town of Kamas, Utah, is well defined topographically as well as structurally. Its east plunge, equally well defined, is near the mouth of the Little Snake River a few miles west of Maybell, Colo.

In a general way this large fold coincides with the mountainous mass of the range, although some of the outer hogbacks and cuestas of the fold extend several miles out from the mountains. Near the east end of the range the anticlinal axis passes beneath the thick basinal fill of the Browns Park Formation, which buries much of the northeast limb. Just east of the Little Snake River, the short but abrupt Cross Mountain anticline straddles the Uinta axis. Curiously, its crestline trends nearly north. Farther southeast the Uinta axis reemerges at the Axial Basin anticline (fig. 3; see also fig. 25).

The range is flanked in many places by high plateaus or mesas, mostly capped by remnants of the once more extensive Bishop Conglomerate. In the western part of the range many of these plateaus exceed $3,000 \mathrm{~m}$ in altitude, and some even reach $3,660 \mathrm{~m}$, but toward the east they are progressively lower, finally dropping below 2,000 $\mathrm{m}$ at Elk Springs Ridge just west of Elk Springs, Colo.

The eastern part of the range is modified on the south flank by several large subsidiary anticlines that increase its breadth and complexity. These folds center around Dinosaur National Monument, and their impressive exposure lends a dramatic dimension to the local scenery. The main Uinta anticline itself is compound in that it consists of two elongate domes, nearly equal in size, alined on a single east-west axis (Hansen, $1957 b ; 1965$, p. 137). These domes are expressed structurally by strike and dip changes in the Uinta Mountain Group and by inward bowings of the flanking forma- 


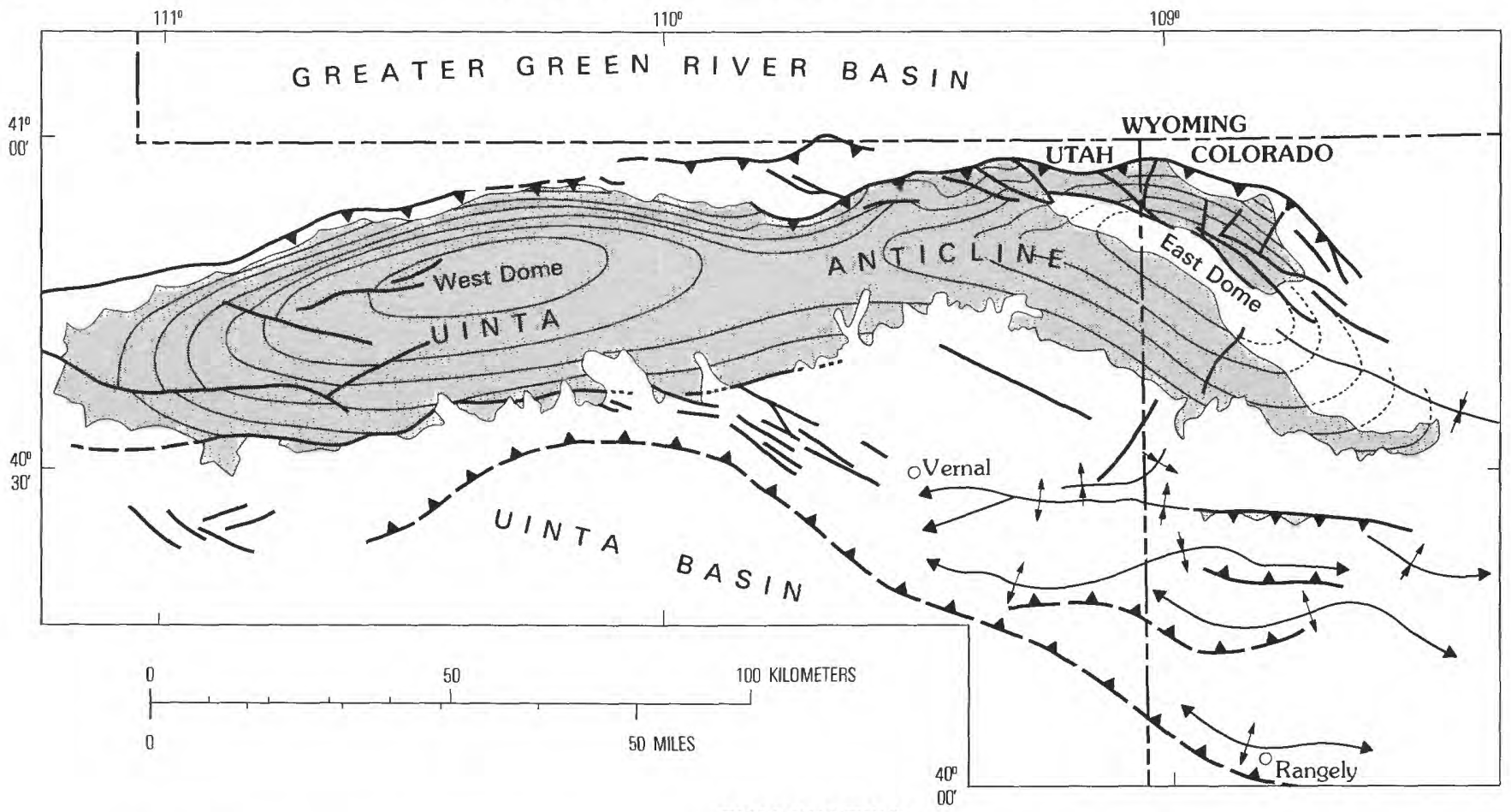

\section{EXPLANATION}


FiguRE 4.-Generalized structure map of the Uinta Mountains showing compound form of Uinta anticline. Modified from Hansen (1957b, fig. 1 ; 1965, fig. 45.) Concealed thrust faults in Uinta Basin after Ritzma (1969). A similar concealed thrust fault may border the range on the north.

tions (fig. 4). They are thus separated by a shallow structural swale across the fold axis, roughly in line with the towns of Manila and Vernal. Both domes are also outlined by relative positive gravity anomalies (Behrendt and Thiel, 1963), which probably result from dense Precambrian rock at shallow depth beneath the range and from density contrasts between the Uinta Mountain Group and the younger rocks of the basins (Behrendt and Thiel, 1963; Cook and others, 1975). The Laramide history of the two domes was roughly the same, but the eastern dome rose higher and has been more deeply dissected, exposing the Early Proterozoic or Archean Red Creek Quartzite. Starting in late Oligocene time, the histories of the two domes took separate turns as the eastern dome began to tilt and subside. In consequence, the summits of the Eastern Uinta Mountains are about $1,200-1,500 \mathrm{~m}$ lower than their western counterparts. The highest point in the Eastern Uintas is Diamond Peak, an outlier off the north flank, which is capped by Bishop Conglomerate and reaches an altitude of $2,960 \mathrm{~m}$.

Though most maps show the Uinta Mountains as a single, continuous mountain range, they actually comprise two structurally and topographically distinct parts, which are differentiated here as the "Eastern Uinta Mountains" and the "Western Uinta Mountains." I draw the boundary between the two at a pass north of Vernal drained by Cart Creek on the north and Reader Creek, a tributary of Little Brush Creek, on the south (Hansen, 1969a, p. 13). Utah Highway 44 traverses the pass, joining Vernal to Manila. Within a few kilometers of this pass, the altitude, physiography, climate, and vegetation change drastically from the lofty, well-watered Western Uintas to the lower, more arid Eastern Uintas. The purpose of this report is to evaluate the Eastern Uinta Mountains, their Tertiary physiographic development, their Neogene structural history, and the ensuing drainage adjustments. 



FIGURE 5.-Generalized distribution of the Browns Park Formation, Bishop Conglomerate, and bare-rock Gilbert Peak erosion surface in the Eastern Uinta Mountains and adjacent areas. 


\section{ACKNOWLEDGMENTS}

I am pleased to express my thanks to the many people who helped make this report possible. Peter D. Rowley and Paul E. Carrara shared geologic-mapping responsibilities in the Eastern Uinta Mountains in the late 1970 's, and they prepared and reviewed maps and articles that bear on my conclusions. Bruce Bryant, who recently remapped the Western Uinta Mountains at a scale of 1:250,000, shared many stimulating discussions with me about the Uinta Mountains in general and the Bishop Conglomerate in particular. Bryant and Carrara both critically reviewed this report and offered many useful suggestions. Peter L. Martin carefully edited the entire report and ferreted out many weaknesses. John R. Dyni, Glen A. Izett, and Stanley J. Luft contributed valuable information from their expert knowledge of the Browns Park Formation and its regional geologic setting. M. Dean Kleinkopf gave helpful advice on structural and geophysical interpretations. Henry W. Roehler cleared up many of my uncertainities about the lower Tertiary rocks. Richard B. Taylor and Raymond L. Parker arranged for photoreconnaissance flights in fixed-wing aircraft over the Eastern Uinta Mountains, flights piloted by Parker and Robert D. Miller. Karen S. Bailey supervised numerous iterations of the manuscript. Bernard W. Hawkins drafted the illustrations. Charles B. Hunt, down through the years, has generated a flood of provocative ideas that have greatly influenced my thinking. All of the above people are or have been affiliated with the U.S. Geological Survey. The National Park Service furnished logistical assistance in the rugged canyon country of Dinosaur National Monument. Andrew E. Godfrey, of the U.S. Forest Service, provided enthusiastic intellectual and physical support in the field, including the use of a helicopter.

\section{GILBERT PEAK EROSION SURFACE}

The Gilbert Peak erosion surface is the pediment on which the Bishop Conglomerate accumulated, named by Bradley (1936, p. 170) for extensive remnants on the north and west slopes of Gilbert Peak on the north flank of the Western Uinta Mountains. This surface is an excellent datum for the reconstruction of Neogene events, having been modified in many places by warping, faulting, and dissection-clues to neotectonic activity in the area. Bradley described in detail the origin and history of this surface as it exists on the north flank of the range, and he discussed its geomorphic relationship with the Bishop Conglomerate. He noted its presence on the south flank, also, but restricted his observations to the north. Powell (1876, atlas) and King
(1878, atlas) in a general way and Schultz (1918, pl. 5 ) in more detail had earlier depicted the extent of the Bishop Conglomerate (and hence the underlying Gilbert Peak surface) on both flanks, but they did not map the extensive and geomorphically critical exposures in the Blue Mountain-Yampa Plateau area or the deposits along the crest of the range near Pot Creek (fig. 5). The Blue Mountain-Yampa Plateau deposits are critical in that their source was the crestal part of the range across the present canyons of the Green and Yampa Rivers. These rivers, therefore, could not have existed at the time of Bishop deposition, and Powell's concept of antecedence, which called for a Green River older than the mountains, is thus invalidated.

Rich $(1910$, p. 615,619$)$ first described the Gilbert Peak surface but did not name it. Rich regarded it as a peneplain, probably formed under humid climatic conditions, and he inferred that the overlying Bishop Conglomerate was deposited in response to renewed uplift of the Uinta Mountains accompanied by a shift from humid to arid conditions. Rich also toyed with the idea of planation by wind erosion under an arid climate. The pediment concept at that time had hardly yet emerged, and Rich attributed the concavity of the Gilbert Peak surface profile to renewed uplift of the mountains. Sears (1924a, p. 302) also identified the surface as a peneplain, but he correctly sensed its basic origin and, in later years, privately referred to it as a pediment. Sears (1924a) suggested that it perhaps merged with a similar plain on the southern flank of the Wind River Range, described by Blackwelder (1915).

At the time of its formation, the Gilbert Peak erosion surface was an extraordinarily broad, monotonously flat plain, better depicted by photographs than by words (figs. 6, 8, 9, and 10). Much of what remains today survives because it is covered and protected by a capping of Bishop Conglomerate. Mountainward parts of the surface on hard rock, however, lack the gravel cap and may have been stripped or may never have been

Figure 6.-Two views of the Gilbert Peak erosion surface.

Top.-A few kilometers downstream from Green River, Wyo., and $65 \mathrm{~km}$ north of the Uinta Mountains. Looking southeast across the Green River toward the Gilbert Peak erosion surface at Flattop Mountain on the skyline. Surface truncates the Wilkins Peak Member of the Green River Formation, which dips right (west) off the Rock Springs uplift.

Bottom.--Red Canyon and north flank of the Uinta Mountains as seen from Bear Mountain, right foreground. Gilbert Peak erosion surface truncates Uinta Mountain Group on Dowd Mountain in the middle distance. Note that the surface here slopes southward (left) toward the mountains. Photographed in 1951 before construction of Flaming Gorge dam, which now backs water into the canyon in the foreground. Compare with views in figure 9. 


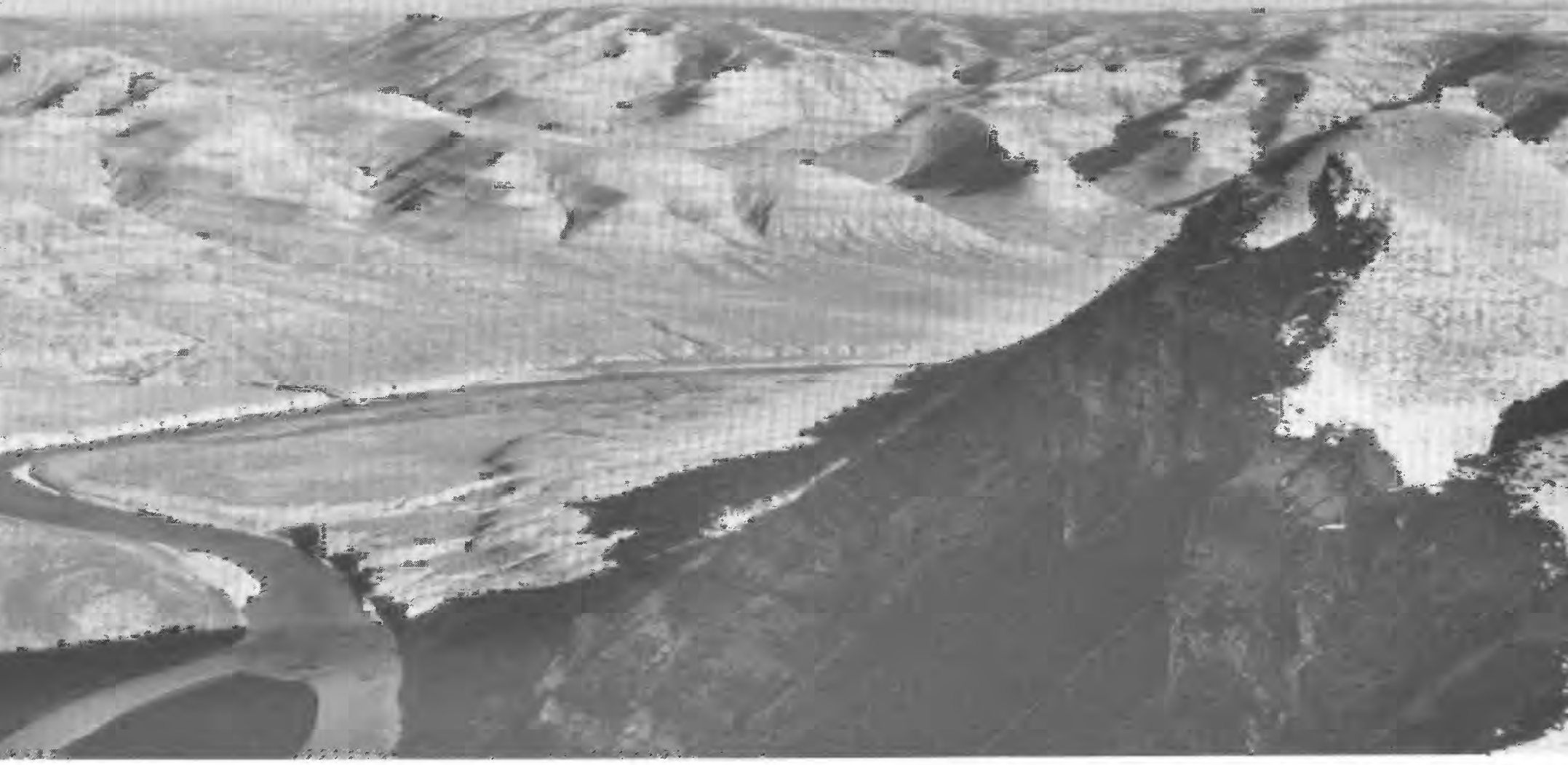

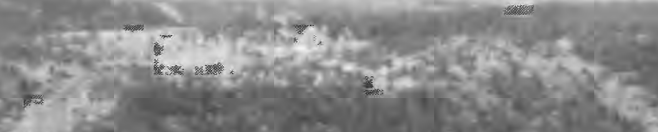

$\frac{10}{4}$

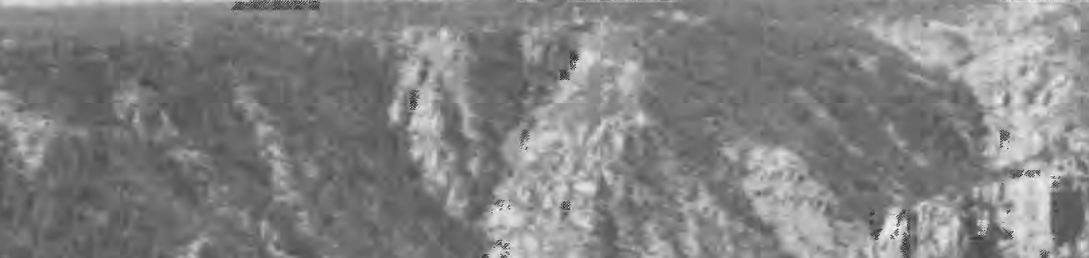

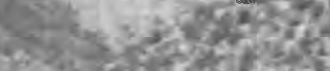


-3.

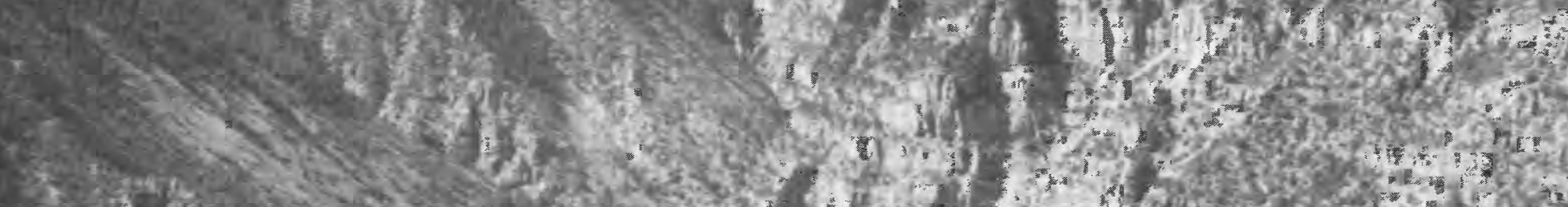
15.

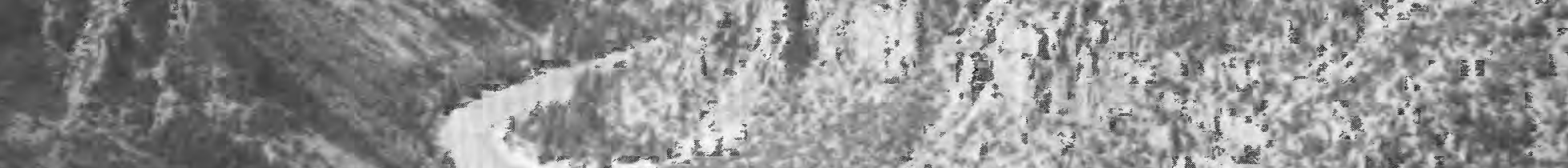

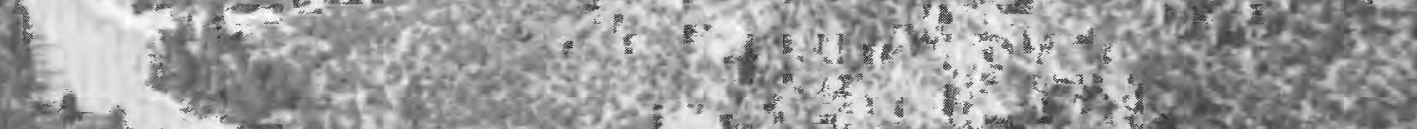

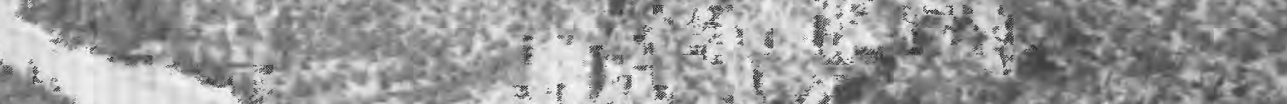








covered. These areas and the higher mountains were the sources of the gravel. The smoothly graded, slightly concave surface sloped gently away from the mountains into the Green River Basin to the north (fig. 7), the Sand Wash Basin to the northeast, the Piceance Creek Basin to the southeast, and the Uinta Basin to the south. In all probability it also extended southeastward some distance across the present Yampa River toward Axial Basin, where it may have merged with a similar surface extending down from The Flat Tops of the White River uplift, although the evidence of such a link has been erased by erosion. According to Bruce Bryant (written commun., 1983) the oldest dated Neogene deposits on The Flat Tops are about 24 m.y. old and thus equate with the older part of the Browns Park Formation rather than the Bishop. The subjacent erosion surface, however, might still be about the same age as the Gilbert Peak surface.

Several even-topped ridgelines far out in the Tertiary basins accord rather closely in altitude with the Gilbert Peak erosion surface, and though they lack a Bishop Conglomerate cap rock, I regard them as likely correlatives of the Gilbert Peak surface. They owe their present prominence to resistant bedrock. Among them are the crestline of White Mountain west of Rock Springs; Kinney Rim and Laney Rim bounding the Washakie Basin on the west and north, respectively; the crest of the Citadel Plateau south of Maybell; Pinyon Ridge south of Elk Springs; Calamity Ridge east of Rangely; and the Cathedral Bluffs rim west of the Piceance Creek Basin. Aspen Mountain, on the Rock Springs uplift, is a monadnock that stood above the old pediment surface. So is Wilkins Peak, southeast of Green River. All these features are shown on figure 1.

The Gilbert Peak surface truncates hard and soft rocks alike, with little regard for lithology or structure, although resistant rocks stand well above the surface locally as hogbacks or monadnocks. The Madison Limestone (Mississippian) in particular has resisted pedimentation more stubbornly than has the Uinta Mountain Group (Middle Proterozoic); its limestone outcrops rise above the truncated Uinta Mountain Group in many places. Limestone Ridge, on the northeast side of Cold Spring Mountain, is just one example. Locally, the Round Valley Limestone (Pennsylvanian) stands above the surface also, especially on the south slope of the range near Vernal. On the higher flanks of the pediment on the south slope of the range, scattered monadnocks or inselbergs (island mounts) surrounded by Bishop Conglomerate merge gradually with the old mature topography of the mountains. In such places the headward parts of the Gilbert Peak surface penetrate deep into the range as a complex of graded or partly graded, flat-bottomed, alluviated, dendritic val-
SOUTHWEST

NORTHEAST

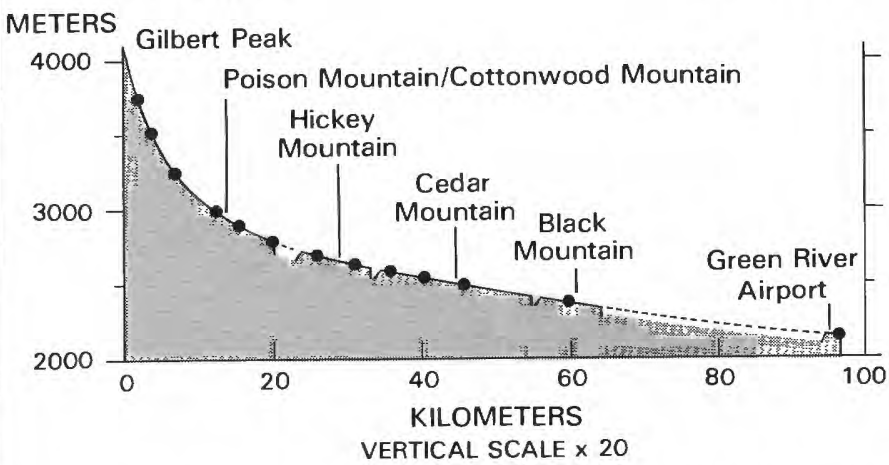

FIGURE 7.-Composite profile of remnants of Gilbert Peak erosion surface between Gilbert Peak, Utah, and Green River airport, Wyoming. Much of the profile as shown depicts the top of the Bishop Conglomerate, which reaches a thickness of about $60 \mathrm{~m}$ at the south end of Cedar Mountain. The remnant at the Green River airport is near the low point of the Gilbert Peak surface and may, in fact, be a slightly lower, younger surface; it supports a gravel deposit that contains pebbles from sources to the north as well as south. The high, steep southern part of the profile near Gilbert Peak is on bare bedrock. The profile, which about coincides with the Hickey Mountain profile of Bradley (1936), is derived from the new 1:100,000-scale topographic maps of the area. Profile dashed where eroded.

leys; basinward, these valleys coalesced with the flanking pediment.

Many such valleys still exist on the south slope of the Uinta Mountains, little changed from their middleTertiary form (fig. 8), especially in the area between Ashley Creek on the west and the Canyon of Lodore on the east. (For example, see Kinney, 1955; Rowley and others, 1979; Hansen and others, 1980, 1981, 1983.) Bradley $(1936$, p. 171) noted places in the western half of the range where ramplike remnants of an old surface (Gilbert Peak?) extend completely across the crest, joining the north flank with the south in a smooth, unbroken profile. The process through which two opposed concave ramps have merged at the crest into a continuously graded convex divide has not been addressed and remains unclear. I suspect that the remmants cited are parts of the Wild Mountain upland surface (p. 14) rather than the Gilbert Peak.

As visualized by Bradley (1936, p. 174), the Gilbert Peak erosion surface was formed in a semiarid environment by laterally corrading streams. Borrowing from Rich $(1910$, p. 614$)$, Bradley cited as evidence the fresh, unweathered character of the truncated rock and the lack of a buried soil beneath the overlying Bishop Conglomerate, and he noted the thinning of the Bishop toward the mountains and toward the basins from a thicker section in between. In an arid climate, mostly intermittent streams flowing away from relatively well- 


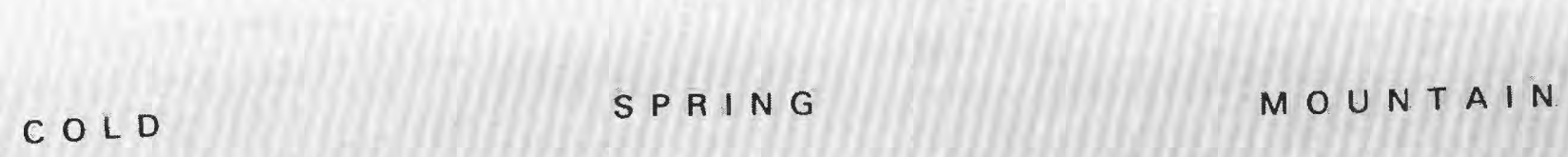

BROWN S

P A R K 
Most of the runoff flowed in ephemeral but occasionally energetic, highly competent streams, and most of it probably failed to reach the centers of the basins. One effect would have been to slightly flatten the depositional profile. At the time of its deposition the Bishop Conglomerate must have formed a nearly continuous bajada around the north, east, and south flanks of the range.

Botanic evidence suggests widespread cool, dry conditions during the latter part of the Paleogene Subperiod, in contrast with warmer, more humid earlier climates (MacGinitie, 1969; Leopold and MacGinitie, 1972). This climatic change has been attributed to widespread explosive volcanism in western and southern North America (Axelrod, 1981), but the tectonic, epeirogenic rise and topographic diversification of the Cordilleran region at that time must have affected the climate also. (See p. 24.)

\section{EXTENT OF THE GILBERT PEAK EROSION SURFACE IN THE EASTERN UINTA MOUNTAINS}

The bare-rock surface of the Gilbert Peak pediment is preserved in many places, though slightly to moderately eroded. In most places, however, the surface is mantled, and protected from erosion, by the Bishop Conglomerate, which rather faithfully reflects its form and extent. (See figs. 9 and 36.)

On the north flank of the range, north of Red Canyon of the Green River, well-preserved but warped remnants of the gravel-free surface truncate the Uinta Mountains Group from Flaming Gorge to Browns Park and include, among others, Bear Mountain (Bare Top), Dutch John Bench, and Goslin Mountain (Hansen, 1965, p. $115,163,171)$. All these places are identified on figure 20. North of Browns Park extensive remnants include Head of Cottonwood, O-Wi-Yu-Kuts Mountain, and Cold Spring Mountain, the latter made classic by Bradley's study (1936). The tops of these mesas are slightly dissected by differential erosion, mostly along shaly zones, but viewed from a distance, most of them appear as almost perfectly flat plains. Cold Spring Mountain is especially noteworthy, but Dutch John Bench alone is almost pristine, virtually unaltered by erosion since middle Tertiary time. Being bare of gravel, except locally, all these remnants must have been near the mountainward limit of the pediment, close to or above the depositional margin of the Bishop Conglomerate, although they are now lower than conglomerate-capped remnants to the north and northeast at Little, Pine, and Middle Mountains and Diamond Peak, having been lowered by subsequent faulting. Local gravel patches were once more extensive than now, having been partly stripped by erosion, but much of the bare-rock surface may never have supported gravel. Bouldery gravel deposits high on the north flank of Cold Spring Mountain above Talamantes Creek (figs. 5 and 40) are remnants of Bishop Conglomerate in my opinion, although some geologists have mapped them as Browns Park. These remnants contain boulders as large as $1.2 \mathrm{~m}$ across.

Farther southeast, on Douglas Mountain, bare-rock remnants of the Gilbert Peak surface also truncate the Uinta Mountain Group. The dissection of these remnants has gone further than that above Red Canyon and Browns Park, but seen in profile they, too, present remarkably even skylines. Remnants of the old surface skirt the northeast slope of Zenobia Peak, along a rough dirt road called Douglas Mountain Boulevard, then are lost in the dissection near Lodore Canyon. ${ }^{1}$ Remnants form the canyon rim farther south in the Zenobia Creek-Pot Creek area, however, and in places they pass under patches of Bishop Conglomerate and younger colluvium (fig. 10; Hansen and others, 1983). At the Gates of Lodore, the flat tops of both canyon rims are isolated remnants of the Gilbert Peak erosion surface also.

On the south side of Douglas Mountain the Gilbert Peak surface has largely been destroyed by dissection. No flat area of any great extent remains, but the form of the restored surface is vaguely preserved in the accordance of ridgelines truncating the Morgan, Weber, and Park City Formations along the north rim of

"The shorter name "Lodore Canyon," generally used locally in preference to the more formal "Canyon of Lodore," will be used in this report.

Figure 9.-Remnants of the Gilbert Peak erosion surface in the easternmost Uinta Mountains area, Moffat County, Colo.

Top.-View across East Cactus Flat, a stripped surface, toward West Cactus Flat in distance and Tanks Peak at upper left. Escarpment of Yampa fault in middle distance at left. Light-colored cliffs in middle distance mark the wall of Yampa Canyon, there about $300 \mathrm{~m}$ deep but mostly out of view.

Middle.-View eastward across Thanksgiving Gorge toward East Cactus Flat in the middle distance and Cross Mountain on the skyline. East Cactus Flat truncates the Weber Sandstone. Cross Mountain is topped by a remnant of the Wild Mountain upland erosion surface truncating the Madison Limestone. The walls of Yampa Canyon catch the sun and shadows in the middle distance.

Bottom.-View east across valley of Little Snake River toward Cross Mountain. Flat bench flanking Cross Mountain in middle distance is capped by Bishop Conglomerate about $45 \mathrm{~m}$ thick resting on Mancos Shale in the center of the picture and on Glen Canyon Sandstone at the far left. Note the gentle tilt of the conglomerate to the left (north). Compare with views in figure 6 . 


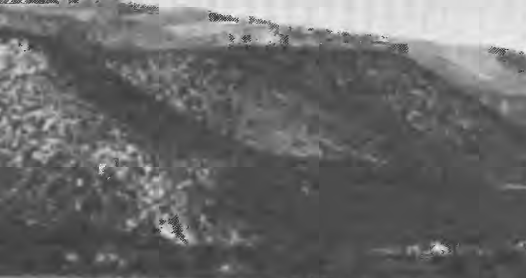

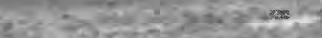

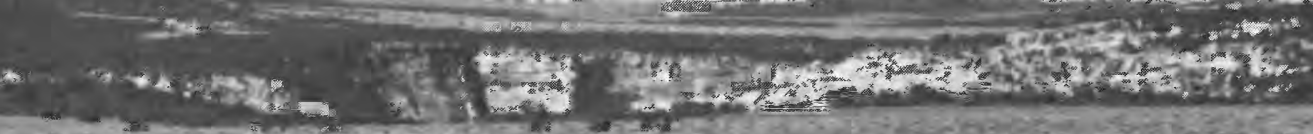

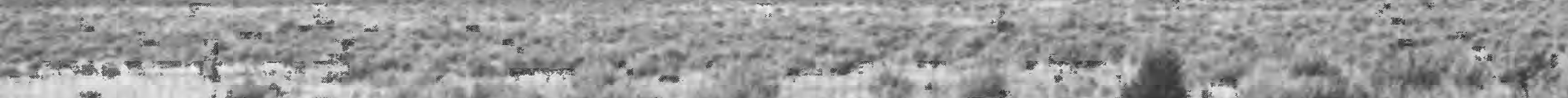

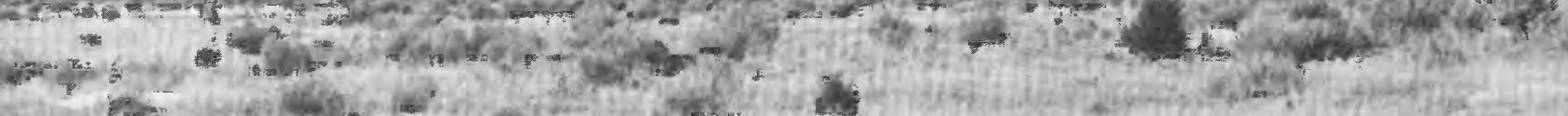



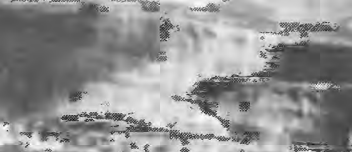

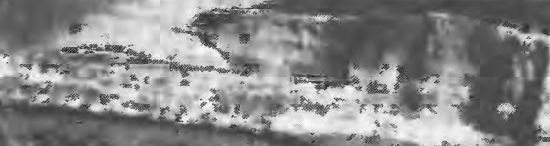

sis.

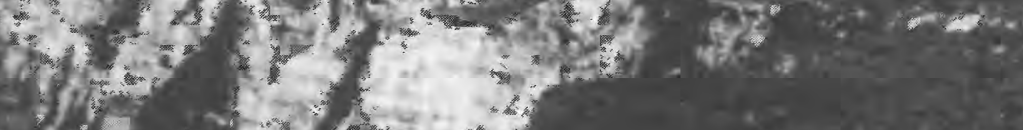

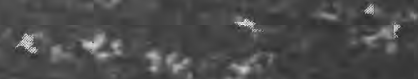



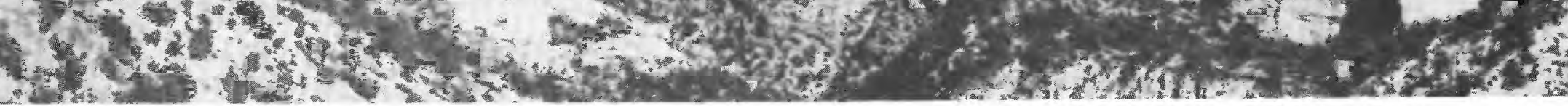




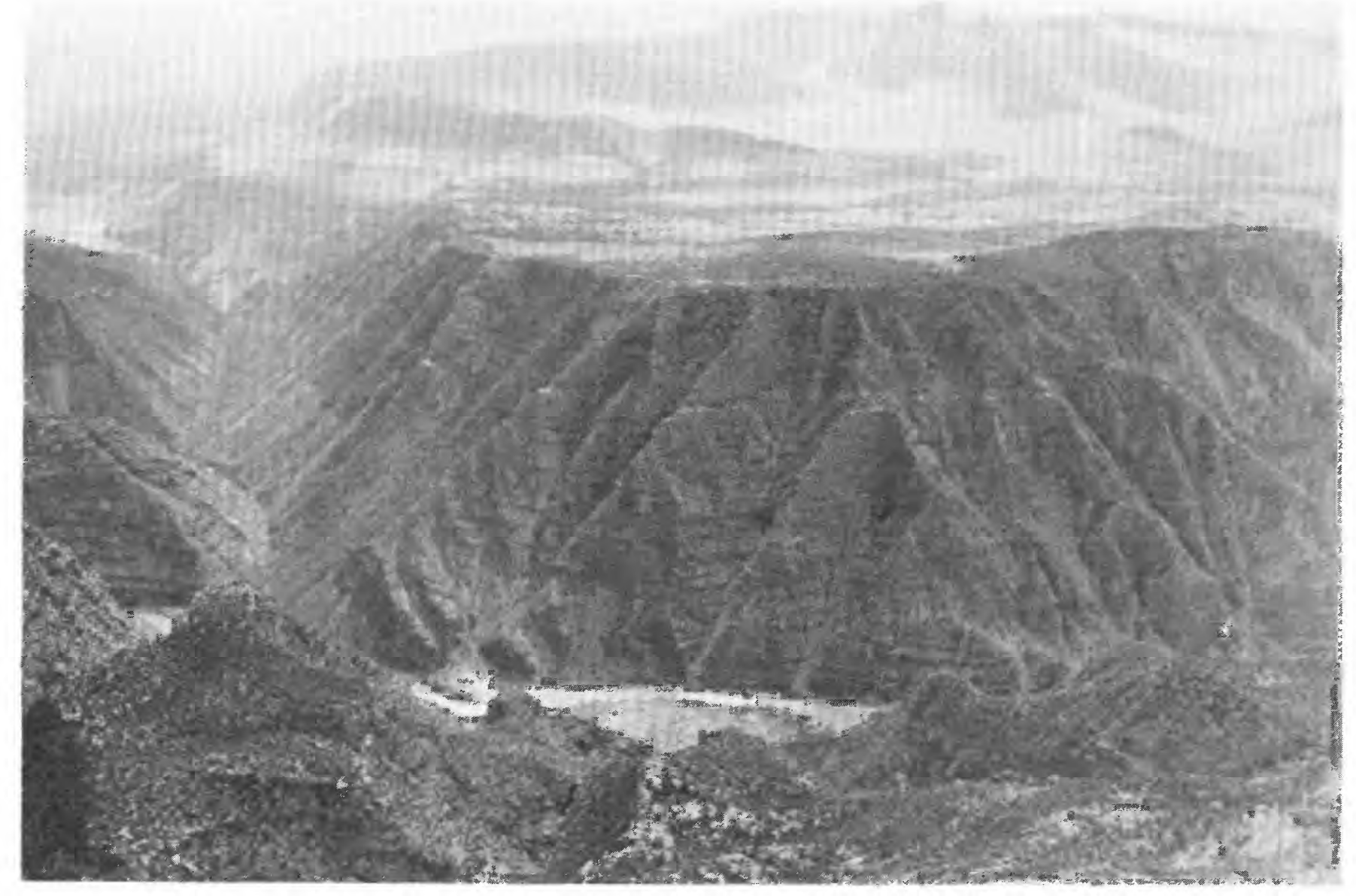

FiguRE 10.-Gilbert Peak erosion surface, forming the east rim of Lodore Canyon downstream from Jack Springs Draw, at left. In the middle distance the surface is mostly bare rock, but in the background it is covered by Bishop Conglomerate and Quaternary alluvium. Canyon wall here is about $715 \mathrm{~m}$ high.

Yampa Canyon in Dinosaur National Monument. Seen in profile, these ridgelines describe a well-formed surface. Near the confluence of the Yampa River with the Green, the restored surface is at about $2,190 \mathrm{~m}$ elevation and slopes gently northward at a rate of about $9.5 \mathrm{~m} / \mathrm{km}$. It accords nicely, therefore, with the base of the Bishop Conglomerate at Harpers Corner to the southwest, slightly higher at about $2,285 \mathrm{~m}$, and with the benchland along Pot Creek to the northwest, a bit lower at about $2,130 \mathrm{~m}$. The restored surface also slopes gradually east at a rate of about $5-6 \mathrm{~m} / \mathrm{km}$ and truncates bedding at an angle of about 6-10 degrees.

\section{THE WILD MOUNTAIN UPLAND, AN OLDER EROSION SURFACE}

Flattish to rolling uplands at various places in the Eastern Uinta Mountains are regarded as remnants of a truncation surface higher and older than the Gilbert Peak erosion surface (fig. 11). This surface, here called the Wild Mountain upland surface, may have been shaped by altiplanation, as its remnants generally lack the smooth gradients of stream-cut profiles. Abundant coarse gravels in the Wasatch and Green River Formations near the mountains indicate intensive early degradation at the flanks of the range and alluviation of the basins, with the added implication that a degradation surface was forming in the mountains at the same time. Some remnants of the Wild Mountain upland surface stand $180 \mathrm{~m}$ or more above the Bishop Conglomerate. In general they consist of resistant bare rock, such as limestone or quartzite, with no surficial cover, and they truncate the subjacent formations without regard for rock structure. Likely candidates include the top of Wild Mountain (figs. 5, 11) in the northwest part of Dinosaur National Monument, for which the surface is named, and Hoy Mountain to the north of Wild Mountain, both at altitudes of $2,620-2,680 \mathrm{~m}$. The top of Offield Mountain east of Hoy Mountain may be a remnant also. Wild Mountain is topped by the Madison Limestone and limestone beds in the Morgan Formation. Hoy and Offield Mountains are composed entirely of 




Figure 11.-Wild Mountain, on skyline, as seen from "Harpers Plateau," looking north. "Harpers Plateau" is the local name of the Bishopcapped mesa southwest of Harpers Corner. Whirlpool Canyon is out of view in the middle distance in front of Wild Mountain. Rolling upland surface of Wild Mountain here truncates the Morgan Formation (Pennsylvanian).

the Uinta Mountain Group. West or north from Hoy Mountain, in the highlands south of Browns Park, no remnants of an upland surface remain, but summit levels there are in good general accordance despite rather complete dissection. These summits are generally highest to the south and west, diminishing in altitude to the north and east. Bradley (1936, p. 171) speculated about the possible existence of a pre-Gilbert Peak surface in more westerly parts of the range, where accordant ridgelines flank many of the higher peaks and locally form the crestline itself. The rolling upland at the head of Ashley and Brush Creeks is regarded here as a remnant of this surface, as it stands $300 \mathrm{~m}$ or more above nearby deposits of the Bishop Conglomerate.

East of Wild Mountain, across Lodore Canyon, the Madison Limestone forms a continuous outcrop about
$40 \mathrm{~km}$ long, reaching to the east end of the range at Lone Mountain; most of the summits on this outcrop are nearly accordant. Here, there is no broad platform either, just a general accordance, declining gently from west to east. Some points, such as Zenobia Peak and Allred Peak, rise well above the general level. Limestone Ridge, ${ }^{2} 5$ miles south-southwest of Greystone, has an even crestline mantled by a felsenmeer of coarse subangular blocks (fig. 12), a product perhaps of long exposure to a harsh, cold climate. Limestone Ridge is about $2,380 \mathrm{~m}$ above sea level, though it must have stood much higher before the tectonic subsidence of the Eastern Uinta Mountains. Both it and Wild Mountain are visible in profile from the Harpers Corner road several miles to the south in Dinosaur National Monument.

${ }^{2}$ The name "Limestone Ridge" is applied locally to at least three separate ridges in the Eastern Uinta Mountains. 




FIGURE 12.-Felsenmeer on the Madison Limestone at Limestone Ridge, Douglas Mountain, about $8 \mathrm{~km}$ south-southwest of Greystone, Colo. The larger rock fragments are about $30 \mathrm{~cm}$ across. The crest of Limestone Ridge is a slightly dissected remnant of the Wild Mountain upland surface.

Along the south flank of the Eastern Uinta Mountains, south of Yampa Canyon, is the extensive Blue Mountain highland. Blue Mountain basically consists of two west-to-east summit ridges separated medially by the drainages of Wolf Creek and tributaries of Hells Canyon. These drainages are partly controlled by old downwarps and faultlines and are partly floored with Bishop Conglomerate. Several broad, nearly accordant summits along Blue Mountain may be remnants of the Wild Mountain upland surface. Noteworthy among these, on the northern ridge, are (1) Round Top Mountain, altitude $2,620 \mathrm{~m}$, topped by limestones of the Morgan Formation; (2) the high ridge between Marthas Peak and Serviceberry Gap (fig. 33), altitude about $2,600 \mathrm{~m}$, also topped by the Morgan Formation; (3) Tanks Peak, altitude 2,657 m, topped by Morgan; and (4) the long ridge north of Bear Valley (fig. 33), topped by the Madison Limestone. This latter ridge extends east from Tanks Peak to Thanksgiving Gorge, sloping gradually from an altitude of about $2,380 \mathrm{~m}$ on the west to about $2,270 \mathrm{~m}$ on the east, a slope of about $13 \mathrm{~m} / \mathrm{km}$. All these summits stand hundreds of meters above nearby deposits of Bishop Conglomerate. Tanks Peak stands even higher, well above the general level, and might be regarded, therefore, as an ancient monadnock on the old Wild Mountain surface.

South of Wolf Creek and Hells Canyon the ridgelines are supported by much younger rock but attain comparable heights. Buckwater Ridge, elevation 2,560 m, and Lazy Y Point, north of the town of Dinosaur and of Skull Creek (fig. 13), are underlain chiefly by the Dakota Sandstone and the Glen Canyon Sandstone respectively. Together they form a rather even-topped ridgeline about $24 \mathrm{~km}$ long, sloping gently eastward and standing $790 \mathrm{~m}$ or so above the valley floor to the south. At the east end is Skull Creek Rim, altitude about $2,330 \mathrm{~m}$.

It is significant that the profiles of all these ridgelines slope eastward. As will be further discussed later, the south flank of the Eastern Uinta Mountains was tilted northward and eastward after the Bishop Conglomerate was deposited, and the eastward tilt is reflected in the slopes of the profiles. The northerly tilt component on the Wild Mountain surface is too fragmentary 
to reconstruct, but subsequent northerly tilt is clearly shown by the attitude of the nearby Bishop Conglomerate.

Cross Mountain, a sharp, fault-bounded local uplift, is separated from the Eastern Uinta Mountains by the Lily Park syncline (Dyni, 1968). Cross Mountain has a truncated crestline that may be a remnant of the Wild Mountain surface. If so, it too has been tilted and in a complex fashion. Unlike the Uinta crestline, however, the crestline of Cross Mountain slopes southward, although the Bishop Conglomerate on the west flank of the mountain shows northward tilting of a later time and at a lesser magnitude. Along the limbs of the Lily Park syncline the Bishop Conglomerate has a northerly tilt of about $9 \mathrm{~m} / \mathrm{km}$.

\section{BISHOP CONGLOMERATE}

\section{GENERAL FEATURES AND DISTRIBUTION}

The Bishop Conglomerate was named by Powell $(1876$, p. 44, 169) for its occurrence on Bishop Mountain (now called Pine Mountain), just north of the Utah-Colorado State line in southern Wyoming (fig. 2), where it is well exposed. Exposures are even better a few miles to the northwest, along the southeast side of Little Mountain and on Black Mountain, west of Flaming Gorge Reservoir in southern Wyoming. Powell's original name, "Bishop Mountain Conglomerate," was shortened by later geologists. The same formation was called "Wyoming Conglomerate" by the geologists of the 40th



Figure 13.-General distribution of Bishop Conglomerate and Browns Park Formation in southeastern Uinta Mountains and some of the principal named geographic features. Formation boundaries generalized from Rowley and others (1979). 
Parallel Survey (King, 1878, atlas, maps 1 and 2). Its distribution along the north flank of the Uinta Mountains is about as shown by Bradley (1936, pl. 34). Its distribution in the Eastern Uinta Mountains shown on figure 13 is generalized from the detailed map of Rowley and others (1979). Its distribution and character in the Western Uinta Mountains have been under study recently by Bruce Bryant of the U.S. Geological Survey. Remnants of the Bishop Conglomerate are more extensive on the south flank of the mountains than on the north but are widespread on both (figs. 5, 13). In the higher, western part of the range, the distribution is somewhat obscured locally by glacial deposits.

Although the Bishop Conglomerate is very widespread on the flanks of the Uinta Mountains, its present distal limit is erosional, and it must have once extended considerably farther from the mountains than now. Presumably it reached nearly to the centers of the adjacent basins, where it may have merged with deposits from other rimming mountain ranges, though it must have been much thinner there than closer to the mountains. Both the Duchesne River and White River flow to the Green in courses that are roughly parallel to the Uinta Basin axis (fig. 1)-the Duchesne all the way from its confluence with the Strawberry, which continues the parallelism westward, and the White downstream from its crossing of the Douglas Creek arch. These rivers likely were established in consequent courses on the old basin floor following the disappearance of Eocene Lake Uinta, but their courses now are well south of the basin axis. Perhaps they were displaced southward by alluvial fans building out from the mountains as the Bishop Conglomerate spread southward, or by a basinward equivalent of the Starr Flat Member (of Andersen and Picard, 1972) of the Duchesne River Formation, or by both formations. At this writing (1982) the possibility seems good that the Bishop and the Starr Flat are equivalent, a view shared with me by Bruce Bryant (written commun., 1982).

In its most characteristic form the Bishop Conglomerate consists of rather loosely cemented bouldery, cobbly conglomerate and coarse, poorly sorted, pebbly, friable sandstone. Locally, in deposits that probably originated as debris flows, the clasts are largely matrix supported. Clasts tend to be subangular to subrounded, but some are very well rounded. The firmness of cementation is varied, and surface exposures are mostly loose and gravelly. The conglomeratic character of the rock is most evident on the sides of steep hills and bluffs where the calcareous cement has not been dissolved away and where the rock may form low cliffs and overhanging ledges. On Black Mountain, west of Flaming Gorge Reservoir (fig. 2), resistant conglomer- ate forms nearly continuous cliffs more than $2.2 \mathrm{~km}$ long.

The coarseness of the rock varies laterally and vertically. In most places the upper meter or so is finer grained than the rock at depth-commonly as fine as pebble gravel but with scattered cobbles and boulders. Figure 14 depicts this characteristic very well. Except in slopeside exposures, the formation may appear to be deceptively fine grained. Away from its source, which was the crestal part of the Uinta Mountains, the rock is progressively less coarse, just as one would expect, owing to attrition of the clasts and to reduced competence of the ancient streams. Along a given drainage line the size (volume) of the largest boulders diminishes exponentially with distance. Regionwide it tends to do the same (table 1). The median grain size of all clasts probably does also, but the formidable sampling required for proof has never been attempted. On any exposures, the maximum clast size greatly exceeds the median. Boulders $2 \mathrm{~m}$ or more in longest diameter are occasionally found several kilometers from the nearest possible source. On the slopes of Diamond Peak in Colorado (not be confused with Diamond Mountain in Utah), where a possible source was only $3-5 \mathrm{~km}$ away, many boulders exceed $1 \mathrm{~m}$ across, and $2-\mathrm{m}$ boulders are not uncommon. Weber $(1971$, p. 168) noted an angular block of red quartzite "over 8 feet long"

TABLE 1.-Maximum observed sizes of clasts in the Bishop Conglomerate and distances from nearest possible sources in the Uinta Mountains

\begin{tabular}{|c|c|c|}
\hline Locality & $\begin{array}{r}\text { Size } \\
(\mathrm{m})\end{array}$ & $\begin{array}{l}\text { Distance } \\
\quad(\mathrm{km})\end{array}$ \\
\hline Diamond Peak, Colo. .............. & 2.4 & 3 \\
\hline Diamond Mountain Plateau, Utah ..... & 3.2 & 10 \\
\hline Near Brush Creek, Utah ${ }^{1}$.......... & 7.6 & 11 \\
\hline Little Mtn., Wyо. ................ & 1.5 & 12 \\
\hline Wapiti Peak, Colo. .............. & 1.5 & 14 \\
\hline Ruple Ridge, Utah ............... & 2 & 19 \\
\hline Elk Springs Ridge, Colo. ${ }^{2}$......... & 1.2 & 19 \\
\hline Miller Mtn., wyo. ............... & 2 & 24 \\
\hline Black Mtn., Wyo. ................ & .8 & 30 \\
\hline Powder Wash gas field, Colo. ........ & .5 & 32 \\
\hline Unnamed mesa N. of Sage Crk., Wyo... & .6 & 39 \\
\hline Aspen Mtn., Wyo. ................ & .2 & 48 \\
\hline Green River Airport, wyo. .......... & .18 & 56 \\
\hline Flat Top Mtn. N. of Baggs, Wyo. ${ }^{3} \ldots$. & .05 & 85 \\
\hline \multicolumn{3}{|c|}{$\begin{array}{l}1 \text { Probably transported by mudflow. } \\
2 \text { The Elk Springs deposit may have had a slightly nearer } \\
\text { arce at Cross Mountain, possibly } 18 \mathrm{~km} \text {. } \\
3 \text { Flat Top Mountain supports no conglomerate-only a } \\
\text { tttering of resistant pebbles, mostly cherts and quartz- } \\
\text { s, including a distinctive red chert common in the Round } \\
\text { lley and Morgan Formations of the Eastern Uintas. }\end{array}$} \\
\hline
\end{tabular}


Figure 14.-Bishop Conglomerate capping south end of Little Mountain, a high mesa south of Rock Springs, Wyo., elevation 2,788 m. Surface rises toward the south (left) at a rate of $24 \mathrm{~m} / \mathrm{km}$. Conglomerate at surface is deceptively fine grained; for comparison with more typical rock, see figure 15 , which was taken to left of automobile and just below rim of mesa. Uinta Mountains in background have been lowered by post-Bishop subsidence.

$(>2.4 \mathrm{~m})$ near the top of Diamond Peak. Such a block must have been transported by mass wastage, perhaps by a debris flow.

Rich (1910, p. 610) observed that boulders $<1.5 \mathrm{~m}$ in diameter were common at the southern end of Miller Mountain $24 \mathrm{~km}$ from the nearest possible source, although cobbles and pebbles predominate. I measured one boulder there that was $2 \mathrm{~m}$ across. At Lookout Mountain in Sand Wash basin, 19-24 km from the nearest possible source, pebbles and cobbles predomi- nate, although occasional boulders exceed $0.76 \mathrm{~m}$. Thirteen to fourteen kilometers farther distant, just south of Powder Wash gas field, a gravelly bench that is geomorphically continuous with Lookout Mountain contains very few boulders larger than $46 \mathrm{~cm}$, and most of the clasts are less than $20 \mathrm{~cm}$ across. This deposit is about $32 \mathrm{~km}$ from the nearest possible source. At Elk Springs Ridge, near the east end of the Uintas, boulders $1.2 \mathrm{~m}$ in diameter must have travelled 18-19 $\mathrm{km}$. Here, also, pebbles and cobbles predominate. At 
Wapiti Peak, which is near the east end of Elk Springs Ridge, Dyni (1980) noted boulders as much as $1.5 \mathrm{~m}$ across, $14 \mathrm{~km}$ from a nearest possible source. At the shoulder of Aspen Mountain, south of Rock Springs and $48 \mathrm{~km}$ from the nearest possible source, pebbles predominate, and the coarsest material consists of small cobbles (about 8-20 cm). Size gradations are similar on Cedar Mountain, west of the Green River in Wyoming (Bradley, 1936, p. 172).

On the south flank of the range, from Ashley Creek eastward to Little Brush Creek, occasional groups of large angular quartzite blocks, "some individuals weighing several tons," were noted by Kinney (1955, p. 115), who attributed their transport to mudflows. Just west of Utah Highway 44, I measured one tabular boulder that was $7.6 \mathrm{~m}$ long and saw others that may have been larger. The very poorly sorted, matrix-sup- ported texture of the conglomerate in other places also suggests mass transport. In the Yampa Plateau-Ruple Ridge area of Dinosaur National Monument I have seen 2-m boulders $19 \mathrm{~km}$ from their nearest possible source, but boulders this size in some places are clast supported and appear to be fluvial rather than colluvial. Figure 15, for instance, shows three very coarse, inversely graded, clast-supported bedding units passing upward from pebble conglomerate at the base to boulder conglomerate at the top. Bedding thicknesses are about 1-21/2 m. Upward coarsening of flood deposits has been noted by previous workers. In a tractive load under high-energy transport, the coarsest particles tend to rise toward the top (Bagnold, 1954; Scott and Gravlee, 1968). This bedding habit, however, may also result from torrential flooding, rising to a gradual peak of intensity, then declining rapidly. If normally graded

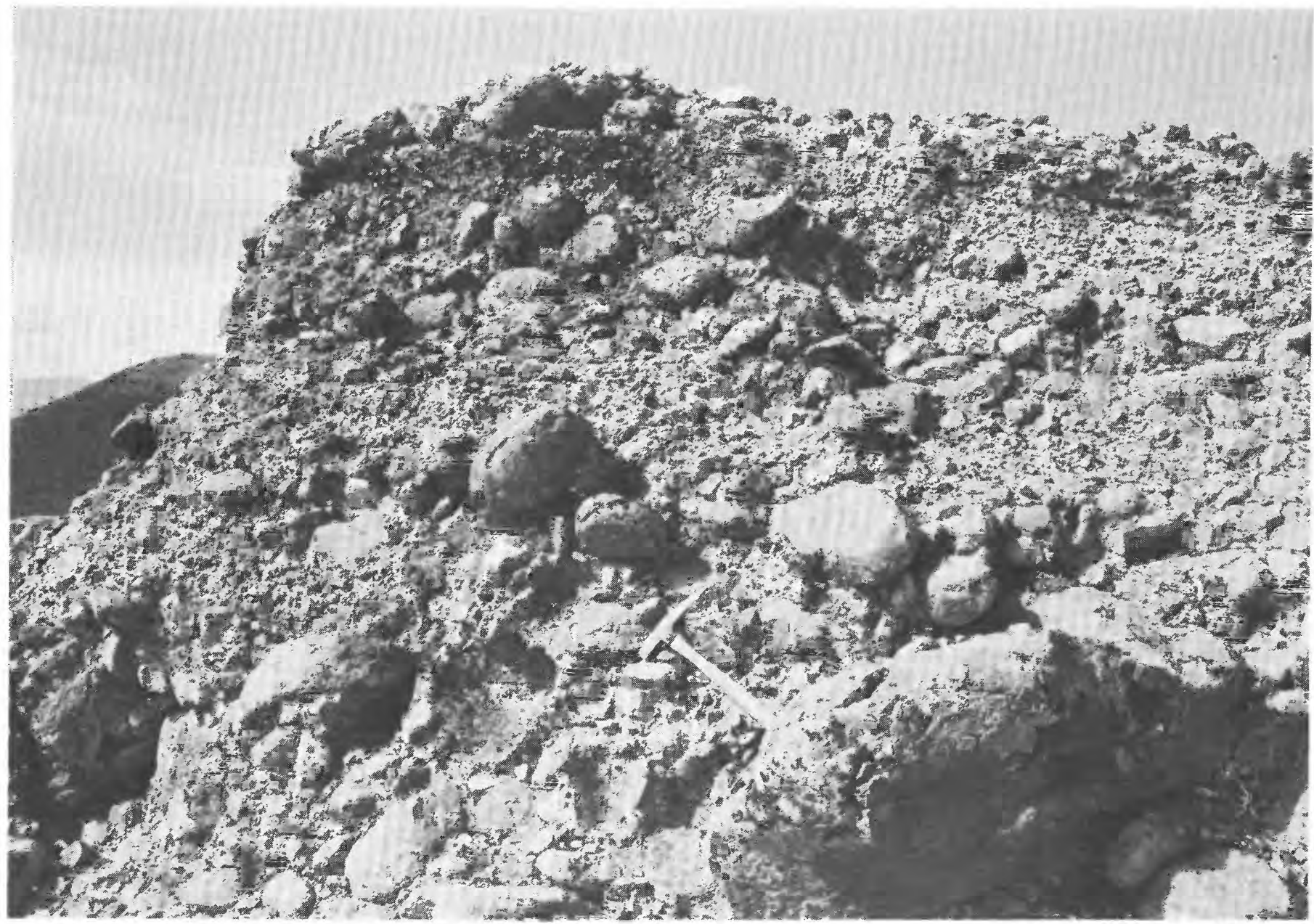

Figure 15.-Bishop Conglomerate at the southwest rim of Little Mountain, Sweetwater County, Wyo. Three coarse, inversely graded bedding units grade from pebble conglomerate at the base to boulder conglomerate at the top. Clasts are subrounded to well rounded. The hammer is about $33 \mathrm{~cm}$ long. 


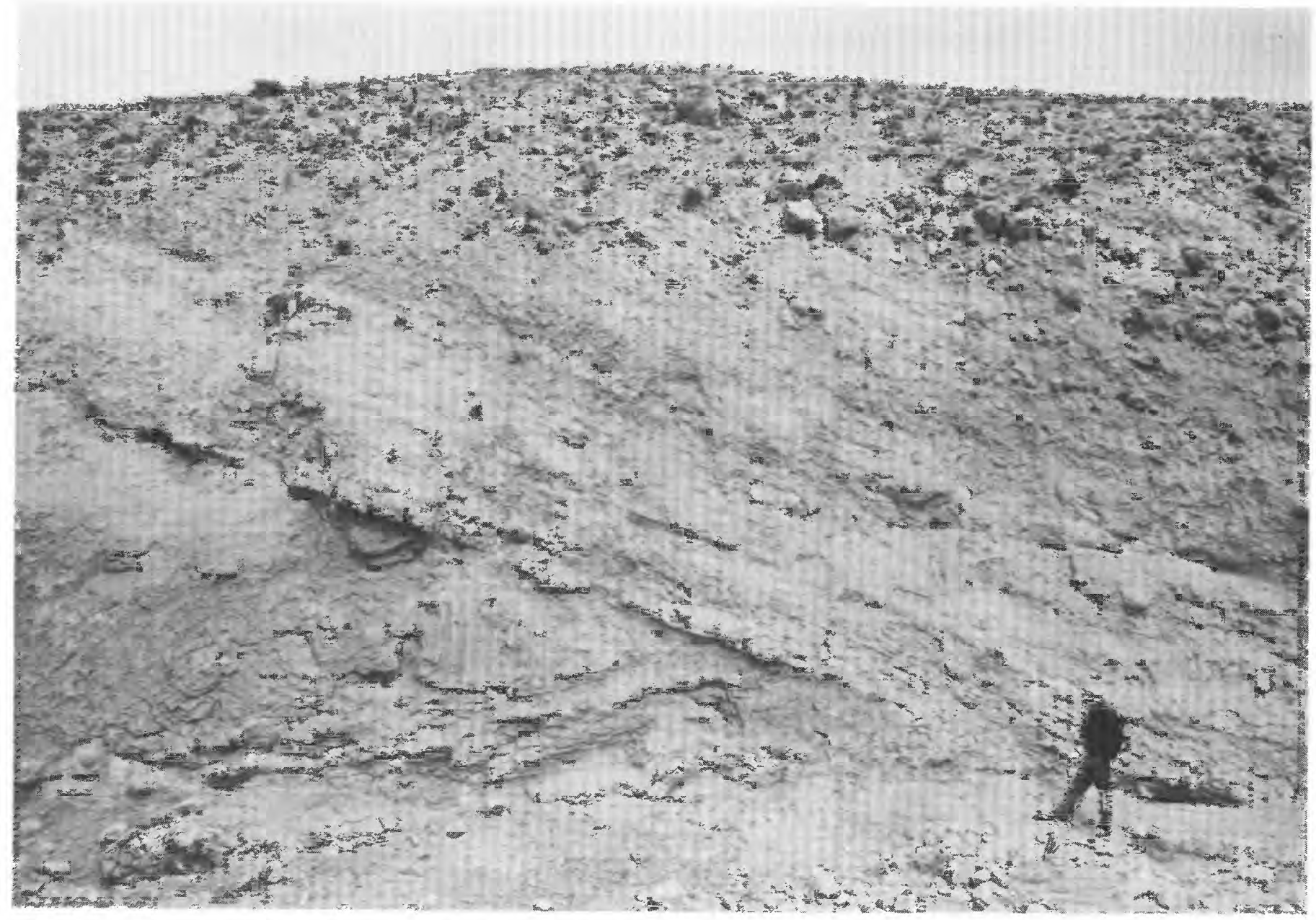

Figure 16. - A coarsening-upward sequence of beds at the base of the Bishop Conglomerate at Sand Wash, Moffat County, Colo. Dipping to the right, the Bishop rests unconformably on the Bridger Formation. About $30 \mathrm{~m}$ of section is visible in this view, but the upper part is greatly foreshortened by perspective. Boulders near the top of the picture are as much as $1.2 \mathrm{~m}$ across.

sedimentation accompanied the decline, as seems likely, its deposits may have been stripped by the next succeeding flood, inasmuch as the tops of the bedding units show evidence of scour.

Coarsening upward on a sequential scale, rather than a bedding scale, is well exposed at Sand Wash (fig. 13), where the Bishop rests unconformably on the Bridger Formation (fig. 16). Several bedding units are involved in a gradual upward coarsening over a stratigraphic distance of $20 \mathrm{~m}$ or more, from pebbly silty sandstone at the base to boulder conglomerate at the top. Similar, but cyclothemic, gradations elsewhere (Steel and others, 1977, for example) have been attributed to tectonic activity. Increased aridity, accompanied by more intense but less frequent flooding, might have achieved the same end at Sand Wash.

\section{LITHOLOGY AND THICKNESS}

Local sources of the Bishop Conglomerate are apparent in the varied lithology of the formation. Red quartzite or sandstone derived from the Uinta Mountain Group is the most abundant clast in general, but in some places gray Paleozoic limestone clasts outnumber those of all other lithologies, including red quartzite. At Cedar Mountain in Wyoming the abundance of limestone cobbles and the paucity of red quartzite suggest that limestone was more widely exposed in the mountains south of there when the Bishop was deposited than it is now, much of it having since been stripped away. Limestone predominates on Black Mountain also. The chief sources were the Madison and Round Valley Limestones, although some limestone may have been 
reworked from Tertiary conglomerate at the flank of the mountains. Much of the Uinta Mountain Group in the source area at that time must have been concealed. In the Eastern Uinta Mountains also, the Round Valley and the Morgan (Pennsylvanian) were important sources for the Bishop Conglomerate along the south slope of Blue Mountain and in local remnants along Douglas Mountain; these formations yielded distinctive clasts of red chert as well as limestone. Along Wolf Creek, Bear Valley, and Klauson Pasture, limestone cobbles greatly outnumber red quartzite because of the wide extent of the outcropping limestone and the distance to a source of the Uinta Mountain Group. South of Rock Springs on Little, Miller, Pine, and Aspen Mountains, but not on adjacent Diamond Peak, distinctive clasts of white to pale green metaquartzite, amphibolite, and other metamorphic rocks were derived from sources to the south in the Red Creek Quartzite (Early Proterozoic or Archean). The transporting streams simply picked up and redeposited whatever rocks were in their drainage paths, and the more abundant, more resistant rock types selectively became predominant.

The thickest sections of Bishop Conglomerate are on the south flank of the Uinta Mountains. Near the Uinta River at Jefferson Park, Kinney (1955, p. 115) noted a thickness of $244 \mathrm{~m}$ consisting mostly of light-tan to red boulders in a matrix of coarse sandstone. Bruce Bryant (oral commun., 1981) suspected that at least part of this section should be assigned to the Starr Flat Member (Oligocene?) (of Andersen and Picard, 1972) of the Duchesne River Formation. Kinney (written commun., 1959) expressed a similar suspicion years before. The Bishop may thus merge downward and basinward in the Uinta Basin with the Duchesne River Formation, although the contact relationship remains unclear, and a sizable hiatus could exist. Bryant (written commun., 1982) recently obtained fission-track dates very close to the age of the Bishop from tuff beds that he considers to be Starr Flat: 30.0, 30.6, and 34.0 m.y.

East from Jefferson Park the Bishop Conglomerate thins rather uniformly, according to Kinney (1955), to about $90 \mathrm{~m}$ near the west end of Diamond Mountain Plateau. Near the southeast end of the plateau, however, a magnificently exposed section about $200 \mathrm{~m}$ thick is nearly all conglomerate. In other places on Diamond Mountain Plateau, coarse, poorly sorted, light-gray sandstone predominates over conglomerate. The sandstone is very calcareous, and some of it is tuffaceous. Kinney (written commun., 1959) suspected that all these rocks correlate in time with the White River Formation (Oligocene) of the High Plains region and the Wyoming Basin, a correlation since confirmed by radiometric dating. (See "Tuff" section, below.) Tuff beds on Diamond Mountain, the Yampa Plateau, and Blue Mountain include air laid(?) tuff that contains phenocrysts of fresh black biotite and hornblende.

Near Jones Hole, the thickness of the Bishop Conglomerate, including tuff and sandstone, may reach 150 m (Hansen, 1977b). No such thickness exists anywhere farther east on either flank of the Uinta Mountains. At the type locality on Pine Mountain the thickness is $60-75 \mathrm{~m}$ (Roehler, 1972a, b). On the Yampa Plateau and on Blue Mountain, thicknesses range from as much as $60 \mathrm{~m}$ to as little as a thin skin, depending largely on topographic irregularities on the local substrate and on random post-Bishop erosion (Hansen and Rowley, 1980a, b). At Klauson Pasture at the east end of the Uinta Mountains, the conglomerate is about $60 \mathrm{~m}$ thick (Rowley and others, 1979). Bradley (1936, p. 172) noted that, on the north flank of the range, the formation attains its maximum thickness near the Utah-Wyoming State line (generally less than $60 \mathrm{~m}$ ) and thins irregularly to the north and south. It rises in altitude southward and thins against the bare Gilbert Peak erosion surface. Northward the conglomerate "thins very gradually and before dissection *** presumably extended far out into the basin" (Bradley, 1936, p. 172). Bruce Bryant (written commun., 1983) has observed stratigraphic sections as thick as $150 \mathrm{~m}$ just north of the North Flank fault zone in the Blacks Fork drainage, west of where Bradley did most of his work.

\section{SANDSTONE}

Much of the upper part of the Bishop Conglomerate as mapped on the south flank of the Uinta Mountains, and locally the lower part, is friable calcareous sandstone, light gray to pale pink, coarse grained, poorly sorted, and poorly bedded. This sandstone resembles somewhat the sandstone in the Browns Park Formation and might in part be stratigraphically equivalent, but my impression is that it is much less well sorted and that its individual grains, which commonly are pink, are generally subangular, whereas most of the sandstone in the Browns Park is fine grained, is moderately well sorted and well bedded, and has well-rounded grains (Luft and Thoen, 1981). The sandstone in the Bishop also generally contains abundant small rock fragments, mica, and scattered dark grains. Individual beds in both formations, however, depart widely from the perceived norm, and they range through a wide spectrum of color, grain size, and sorting. The Bishop contains nothing comparable to the striking eolian sand that is so abundant in the Browns Park Formation in 
the Maybell-Elk Springs area or to the fresh vitric, crystal-poor, mafic-poor tuffs of the Browns Park Formation in the type area. These tuffs are much younger than any known in the Bishop.

I suspect that deposition continued without much interruption on the south flank of the Uinta Mountains, generally fining upward, while the sands were accumulating above the conglomerate. Locally steep dips in the Pot Creek area suggest eolian deposition. Deposition ended when tilting and faulting changed the hydrologic regime and initiated dissection. At the east end of the range, however, large-scale subsidence produced a structural sag that provided catchment for sediments throughout most of succeeding Browns Park time. In Browns Park itself, several million years elapsed after deposition of the Bishop Conglomerate before the Browns Park Formation began to accumulate, and a great deal of geomorphic history intervened.

\section{TUFF}

Tuff was introduced at times into the Bishop Conglomerate, explosive volcanism being widespread during that period in the Western Interior (Axelrod, 1981, fig. 2). Datable tuffs on Diamond Mountain and the Yampa Plateau provide clues to the minimum age of the conglomerate. Southern Utah and central Nevada are possible sources (Rowley and others, 1975, p. B9; Burke and McKee, 1979, p. 183). Biotite and hornblende from a sample collected above the main body of conglomerate by Glen A. Izett and me in the SW $1 / 4$ sec. 13 , T. 2 S., R. 23 E., have radiometric potassium-argon ages of about 29 m.y. (biotite, $29.50+1.08$ m.y.; hornblende, $28.58+0.86$ m.y.) as determined by Harald H. Mehnert of the U.S. Geological Survey, using the following constants:

$$
{ }^{40} \mathrm{~K} \lambda_{\epsilon}=0.581 \times 10^{-10} / \mathrm{yr} \quad \lambda_{\beta}=4.962 \times 10^{-10} / \mathrm{yr} \quad{ }^{40} \mathrm{~K} / \mathrm{K}=1.167 \times 10^{-4}
$$

The height of this tuff above the base of the conglomerate can be estimated at about $90 \mathrm{~m}$ if the dip ( $3^{\circ} \mathrm{NNE}$.) is projected northward to the outcrop from the basal contact at the rim of Diamond Mountain Plateau and if corrections are added for about $30 \mathrm{~m}$ of displacement on intervening faults.

This tuff bed and others overlie most of the conglomerate, but they are interbedded with and overlain by loose, coarse-grained pebbly sandstone. Some of the sandstone might be appreciably younger than the dated tuff, therefore, and might be temporally equivalent to some part of the Browns Park Formation. The lower, coarsely conglomeratic part of the formation, however, could be appreciably older than the tuff; its maximum possible age is limited by the subjacent Duchesne River Formation. Emry (1981) has suggested that the vertebrates of the Duchesnean land mammal age are partly Eocene Uintan (Brennen Basin Member of Andersen and Picard, 1972) and partly Oligocene Chadronian (Dry Gulch Creek and Lapoint Members of Andersen and Picard, 1972). The Lapoint Member underlies the Starr Flat, which in turn may be equivalent to the Bishop Conglomerate.

The dated tuff is light gray, compact, firm, and flecked with abundant euhedral biotite, much of which is coarser than $0.5 \mathrm{~mm}$ across (Hansen, 1965, table 3). The tuff is further distinguished by abundant crystal fragments of feldspar and quartz aggregated with clay, by abundant euhedral hornblende, and by euhedral pyroxene and magnetite commonly adhering to glass shards. The euhedra are deeply etched, and the shards are partly altered to clay. Zircon forms inclusions in the feldspar. What might be the same tuff bed was sampled by Winkler (1970) and dated by Damon (1970, p. 52) at $26.2+0.7$ m.y. (biotite). A tuff near the Harpers Corner road in Dinosaur National Monument is finer grained and rather more altered but is similar in most other respects.

These tuffs resemble the tuffs in the lower part of the Browns Park Formation in the Little Snake RiverMaybell area (Izett and others, 1970, p. C151). This resemblance is the chief reason why the Bishop on the south flank of the Uinta Mountains had been correlated with the Browns Park Formation in recent years (Kinney and others, 1959; Hansen and others, 1960; Untermann and Untermann, 1965).

A tuff collected by Winkler on the Yampa Plateau, about $37 \mathrm{~m}$ above the base of the Bishop, was dated by Damon $(1970$, p. 52$)$ at $41.3 \pm 0.8 \mathrm{~m} . \mathrm{y}$. from a biotite separate. The biotite was brownish black and slightly resinous (Damon, p. 53), which suggests incipient alteration (Mauger, 1977, p. 23). I am inclined to discount this date because of its wide disparity with the ages from the nearby Diamond Mountain localities and because of contradictory geomorphic evidence for the age of the Bishop. This date lies within the age of the saline facies of the Uinta Formation at Duchesne, Utah (Damon, 1970, p. 51; Mauger, 1977, p. 19, 32), and is close to the age of the Green River-Uinta Formation boundary in the western Uinta Basin. A correlation of the Bishop with these rocks is improbable. The Eocene rocks on both flanks of the Uinta Mountains are deeply truncated by the Gilbert Peak erosion surface, including the Wasatch, Green River, and the Bridger Formations and probably the Duchesne River Formation, and an enormous amount of post-Green River erosion took place before the overlying Bishop was deposited. 


\section{PHYSICAL GEOGRAPHY AT THE ONSET OF DEPOSITION OF THE BISHOP CONGLOMERATE}

When the Eocene lakes disappeared from the basins bordering the Uinta Mountains 45-40 m.y. ago (Mauger, 1977, p. 37), they were supplanted by alluvial plains. A detailed discussion of this complex transition is outside the scope of this report, but a brief summary might help place into perspective the middle Tertiary events that followed. Ryder and others (1976, p. 511) aptly described the extinction of Lake Uinta south of the Uinta Mountains in just two sentences:

Following the deposition of strata containing the richest oil shale of Lake Uinta, the water became hypersaline, and the remaining oilshale and mud-supported carbonate units are therefore associated with sodium-rich evaporite and Magadi-type chert beds. By late Eocene and early Oligocene time, the last vestiges of Lake Uinta were buried by coarse alluvial sediments (Uinta and Duchesne River Formations) derived mainly from the Uinta uplift.

West of the present Uinta Basin, Lake Uinta persisted locally, as a freshwater lake, into Oligocene time (Weiss, 1982), but as the basin gradually filled with sediment, its rim was overtopped to the south, and drainage was southward out of the basin from that time on (Hunt, 1969, p. 94). The disappearance of the lakes was accompanied by climatic cooling that Roehler (1974, p. 58) has suggested was triggered by volcanism, a concept recently emphasized in a broad sense by Axelrod (1981) for the whole of the Western Interior during Cretaceous and Tertiary time. Roehler (written commun., 1983) cites evidence of worldwide cooling 38 m.y. ago. Tectonism probably was a factor also. A continued rise of the Uintas and other Rocky Mountain uplifts surely would have altered the local climate.

The extinction of Lake Gosiute north of the Uinta Mountains in middle Eocene time was caused by sedimentation in a lake that was a playa most of the time, in the view of most investigators (Eugster and Surdam, 1973; Bradley, 1973; Eugster and Hardie, 1975; Surdam and Wolfbauer, 1975; Surdam and Stanley, 1979), although Desborough (1978) and Boyer (1982) have recently raised doubts about the playa-lake model. At any rate, the last major stage of Lake Gosiute (the Laney stage) was predominantly fresh until its disappearance and must, therefore, have had an outlet, presumably south into Lake Uinta (Bradley, 1929 , p. 89, 1964, p. A2; Roehler, 1965, p. 147; Surdam and Stanley, 1979, p. 101, 105) by way of the Sand Wash Basin. A physical connection at times between the two lakes, moreover, is indicated by their common fish faunas.

One or the other or both of the lakes probably drained east at times to the Mississippi Valley. If Lake
Uinta received the overflow of Lake Gosiute, it in turn may have drained east across Colorado during its freshwater stages via some unknown outlet to the Mississippi Valley, where the affinities of the well-known fish faunas of the Green River Formation chiefly lay. The numerous gars, catfish, perches, bowfins, paddlefish, mooneyes, herrings, and perhaps sunfish (Priscacaridae) (Grande, 1980) were all members of eastern American families (Miller, 1958; Uyeno and Miller, 1963), none of which is indigeneous to the Colorado River system, and most of which are unknown in the Eocene faunas of the Pacific Northwest (Grande, 1980). If these fishes entered Lake Uinta from Lake Gosiute, rather than vice versa, the chief high-water outlet of Lake Gosiute might have been east across Wyoming to the Mississippi. Such easterly overflow might have followed a rise of both lakes to a common high water level. In either event, the fish faunas suggest that the Continental Divide in Eocene time was west of the Green River lakes and the Uinta Mountains, a likelihood that is compatable with Eocene paleogeography. The Colorado River system at that time did not yet exist. None of the 14 species of fishes native or endemic to the present Upper Colorado River system (Behnke and Benson, 1983), moreover, had progenitors in the Green River lakes except, perhaps, the wide ranging suckers (Catostomidae), which are Nearctic in their distribution. The indigenous Salmonidae (trouts) and Cottidae (sculpins) of the modern Upper Green River and the Columbia are known in North America from the Eocene (Miller, 1965; Patterson, 1981, p. 276) but are not present in the fish fauna of the Green River Formation.

A contributing cause of the disappearance of both lakes was a decrease in tectonic downwarping, which enabled depositional filling to overtake subsidence. The Uinta Mountains, however, probably continued to rise, as shown by the accumulations of coarse conglomerate above the Green River Formation close to the south flank of the mountains, in the Duchesne River Formation (Andersen and Picard, 1972). In most places this conglomerate is gently tilted, locally to as much as 30 degrees. On the north flank at Phil Pico, a thick pile of conglomerate contains rocks of Wasatch, Green River, and Bridger age (Bradley, 1964, p. A53; Rowley and others, 1979). Downwarping continued in the Uinta Basin while most of the Duchesne River Formation was being deposited, followed by regional uplift, probably starting in early Oligocene time. This uplift terminated the long depositional cycle that had begun in the basin with the Laramide orogeny. To the north in the Green River Basin, reelevation of the Rock Springs uplift steepened dips locally to as much as 13 degrees after the Bridger Formation had been deposited but before 
the Bishop Conglomerate had (Bradley, 1964, p. A14). The stage was being set for the cutting of the Gilbert Peak erosion surface.

Before the onset of pedimentation the gradient between the foot of the Uinta Mountains and the central parts of the adjoining basins had to be increased enough to change the drainage regimen in the basins from a depositional to an erosional mode. This gradient was achieved by deformation and concomitant erosion, the extent of which has been described by Bradley (1964, p. A16) as follows:

Without departing from its original depositional dip, the Bishop Conglomerate bevels the tilted Bridger and Green River Formations and the more steeply inclined Upper Cretaceous rocks of the Rock Springs uplift.

The extensive erosion surface on which the Bishop Conglomerate was deposited indicates qualitatively that the post-Eocene deformation must have occurred appreciably earlier than the cutting of this erosion surface. In the Green River Basin this extensive surface bevels beds high in the Bridger Formation, and farther east it cuts progressively lower in the Tertiary; at Pine Mountain and Diamond Peak (near the junction of Wyoming, Colorado, and Utah) it bevels rocks that belong to a tongue of the Wasatch Formation which overlies the basal unit of the Green River Formation. These formations, therefore, must have been deformed long enough prior to the deposition of the Bishop Conglomerate to permit the removal of several thousand feet of beds over a large area and to allow for the reduction of the terrain to a remarkably smooth surface.

To erode all that rock, the drainage needed a new base level, and strong uplift was needed to provide the gradient. At the close of the Green River epoch the floors of the basins were only $150-300 \mathrm{~m}$ above sea level (Bradley, 1929, p. 89; MacGinitie, 1969, p. 52, 73), and the gradient of the basin floors was only about $0.2-0.4$ $\mathrm{m} / \mathrm{km}$ (Bradley, 1964, p. A16). But the graded relief on the Gilbert Peak erosion surface is hundreds of meters. The surface truncates rocks of Precambrian to Eocene age, and it slopes as much as $7-19 \mathrm{~m} / \mathrm{km}$ across the Tertiary basin sediments alone. The relief is more than $600 \mathrm{~m}$ across the southeastern part of the Green River Basin between Pine Mountain on the south and Pilot Butte on the north. This profile, which cuts deeply into the Cretaceous of the Rock Springs uplift, may have been warped, according to Bradley (1936, p. 186), but the relief is just as great on undeformed profiles $100-115 \mathrm{~km}$ to the west, cut entirely on the Bridger Formation.

The Gilbert Peak erosion surface thus could not have been cut without strong prior uplift and dissection of the floors of the basins, without a drastic change in base level and local physiography. There also seems to be no way for the Gilbert Peak surface to have been graded to a master stream flowing out of the Green River, Washakie, and Sand Wash Basins into the Uinta or the Piceance Creek Basin, as will be pointed out, although a hydraulic connection across the Uinta axis probably had existed during the deposition of the Laney and the Parachute Creek Members of the Green River Formation (Bradley, 1929a, p. 89; Roehler, 1965, p. 147; Surdam and Stanley, 1979, p. 101, 105). This connection would have formed a narrow strait across the axis at Axial Basin and perhaps would have had an appreciable current. Surdam and Stanley (p. 105) have described a dispersal of volcanic lithic detritus into the Piceance Creek Basin at that time from the Lake Gosiute Basin, an event that would have signaled the filling and demise of Lake Gosiute. Other sources of volcanic detritus are plausible also, as noted further on, and the likelihood that north-to-south drainage persisted across Axial Basin into Gilbert Peak time, at any rate, is remote. Axial Basin was relatively high structurally and topographically by the end of Eocene time and in Gilbert Peak time (before post-Bishop collapse of the eastern Uinta Mountains), and the threshold or strait across Axial Basin would have been correspondingly high.

If early southward drainage ever crossed Axial Basin, it probably was halted before or by the time of the sharp anticlinal rise of Axial Basin at the end of Eocene time. Sears (1924b, p. 300) was first to point out that the early Tertiary rocks of that area (the Fort Union, Wasatch, and Green River Formations) rest on the Cretaceous with no discordance of dip, and, therefore, that Axial Basin was uplifted after their deposition. This time of uplift probably marked the beginning of the disturbance that deformed the Eocene rocks in the adjacent basins and terminated their deposition.

The Washakie Formation of Wyoming and the Uinta Formation of Utah and Colorado are partly equal in age, but "there is no evidence to suggest that they ever were physically connected across the Uinta uplift" (Roehler, 1973, p. 9). Roehler noted lithologic and color differences between the Washakie and the Uinta that indicate independent sources for their clastic fractions. Much of the Washakie, according to Roehler, consists of arkose derived from the Sierra Madre to the east, whereas the Uinta Formation had local sources in the Uinta Mountains. Volcanic ash constituents of the two formations could have had a common source but need not have. Volcanism was widespread at that time (Lipman and others, 1972), and many centers could have contributed. The source of both ash and volcaniclastics in the Washakie appears to have been the Absaroka volcanic field of northwestern Wyoming (Ebens, 1963; Roehler, 1973), but sources in Idaho are possible also (the Challis Volcanics, for example; Armstrong, 1978; Axelrod, 1981, p. 5). The Rattlesnake Hills of central Wyoming (Carey, 1959; Love, 1970) could have contributed, given favorable winds aloft during an eruption. Absaroka ash could have settled in the Uinta Basin, 
and probably did, but ash may also have traveled from igneous centers in western Nevada (Armstrong, 1963) if intrusive bodies there vented to the surface. Tuffs younger than $45 \mathrm{~m} . \mathrm{y}$. may have entered the Uinta Basin from sources in the Sevier orogenic belt (Dyni, 1981, p. 14).

Detrital volcanic material in the Uinta Formation may have had multiple sources also, possibly including nearer sources in Middle Park, Colo., or even the Front Range, where lower Tertiary volcanic and intrusive rocks are abundant (Izett, 1968, p. 22-25; Tweto, 1976, 1979) and where the volcanic cover then must have been wider than now. This detritus might even have reached the Uinta Basin by way of the ancestral Colorado River, which, according to Hunt $(1969$, p. 67 , 70 ), once flowed west into the Uinta Basin via the White River.

By late Eocene time, beginning about 41 m.y. ago, and lasting generally into the Miocene, airborne and perhaps stream-deposited volcanic material might have entered the Uinta Basin from extensive new igneous centers in the Great Basin and adjacent areas, including the Wasatch, Oquirrh, Tintic, and Marysvale areas of Utah, where intrusive and volcanic activity overlapped spatially and temporally (Bassett and others, 1963; Moore and others, 1968; Laughlin and others, 1969; Moore and Lanphere, 1971; Crittenden and others, 1973; Bromfield and others, 1977). Volcanism started in the Marysvale district somewhat later than elsewhere, about $31 \mathrm{~m} . \mathrm{y}$. ago, and persisted intermittently into the Quaternary (Rowley and others, 1975). Once basin-and-range faulting was underway, however, stream-carried detritus no longer could have reached the Uinta Basin from the down-faulted sources in or beyond the Wasatch Range. (For example, see Stokes, 1976; Hunt, 1982.) By various estimates, regional extension, which led to the faulting, could have started as early as 30 m.y. ago (Ingersoll, 1982) or locally as late as $17 \mathrm{m.y.} \mathrm{ago} \mathrm{(Christiansen} \mathrm{and} \mathrm{McKee,} \mathrm{1978,} \mathrm{Ste-}$ ven and others, 1978).

The strongest evidence that drainage did not cross Axial Basin in Gilbert Peak or Bishop time is in the physiographic form of the Bishop Conglomerate itself and its transport direction. Stanley and Surdam (1978) and Surdam and Stanley (1979, fig. 19) reported evidence of south to southeast flow of water from Lake Gosiute toward the Piceance Creek Basin in middle Eocene time. This direction, however, is $100^{\circ}-180^{\circ}$ from the later transport direction and slope of the Bishop Conglomerate on the Gilbert Peak surface, which was north to northeast from the Uinta Mountains across the Rock Springs uplift and the Sand Wash Basin (fig. 17). Any southerly drainage across Axial Basin into the Piceance Creek Basin, therefore, should have ended long before

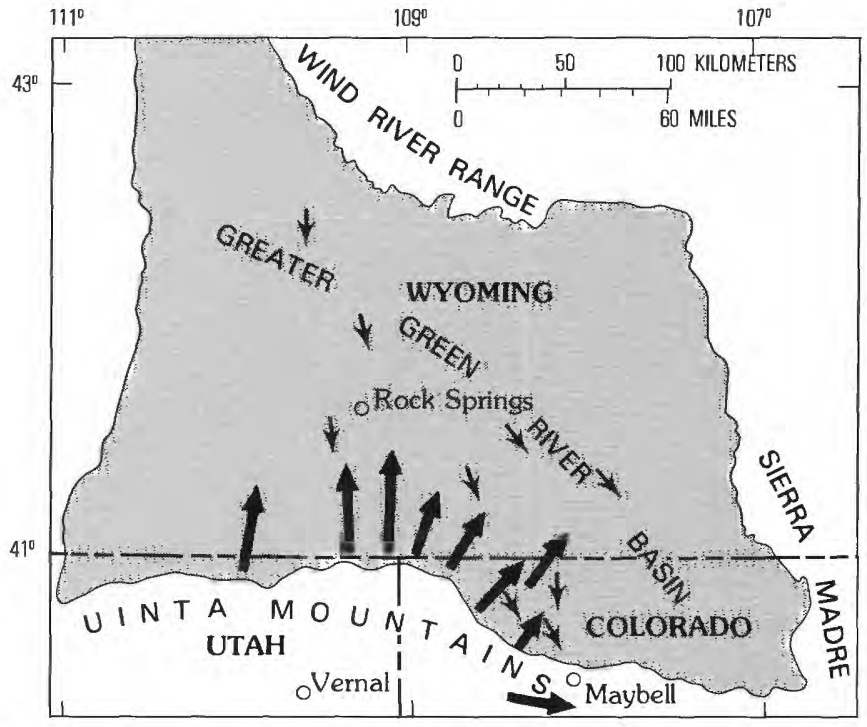

Figure 17.-Directions of foreset bedding and cross stratification in the Laney Member of the Green River Formation (small arrows; from Surdam and Stanley, 1979) and transport directions of Bishop Conglomerate (large arrows) greater Green River Basin area.

the Gilbert Peak erosion surface was formed. Modern south-flowing drainages (such as Sand Wash, the Little Snake River, and Vermillion Creek) postdate the deformation of the Gilbert Peak erosion surface. For example, the Bishop Conglomerate east of Sand Wash had to come from sources to the west or south, opposite or across the present drainage direction; Vermillion Creek flows southwest, but Bishop remnants there slope northeast. Similarly, the course of the Green River farther west is directly opposite the old pediment slope of Hickey, Cedar, Black, Little, Miller, Flattop, and Pine Mountains.

An alternative and more likely direction for a baseleveling stream in the Green River Basin in Gilbert Peak time, therefore, was eastward toward the North Platte River, as first suggested by Bradley (1936, p. $177)$ and as elaborated by Hansen $(1965,1969 \mathrm{~b})$. Ritzma had endorsed the idea in 1959; Sears had hinted at it in 1924 (1924a, p. 304), but it had never received serious attention until my reconnaissance studies of the 1960 's. Such a stream would have provided a geomorphically credible base level for the Bishop Conglomerate. It may have crossed the present Continental Divide at the Great Divide Basin near Tipton, Wyo., skirting the north side of the Rawlins uplift, and perhaps merging with the Sweetwater River. (See section on the capture of the master drainage of the Green River Basin, p. 67.) According to Denson and Chisholm $(1971$, p. C125) the main drainage framework in central and eastern Wyoming was in existence at the close of 
the Eocene, including the courses of the Sweetwater and the North Platte, and persists today with only minor modifications. The Tertiary history of central Wyoming is complex (Love, 1970, 1971), and the exact pattern of drainage is problematical, but it is not incompatible with easterly escape of drainage from the Green River Basin. Even now the Continental Divide at Tipton is $245 \mathrm{~m}$ lower (altitude about 2,070 m) than the base level of the Gilbert Peak erosion surface near the center of the Green River Basin (altitude about 2,315 $\mathrm{m})$.

\section{ALTITUDE AND RELIEF}

To get some idea of regional altitude and relief at the onset of deposition of the Bishop Conglomerate, one may use the top of the Tipton Member of the Green River Formation as a datum and a basis for speculation, since this horizon has wide areal extent. Along with the overlying Bridger and Washakie Formations, the Green River Formation was deformed at the end of the Eocene, and deposition was supplanted by erosion. From the center of the Green River Basin west of Rock Springs to the flank of Pine Mountain about $80 \mathrm{~km}$ to the south, the difference in altitude of the top of the Tipton is about $760 \mathrm{~m}$, judging from maps by Bradley (1964) and Roehler (1972, a, b). This figure essentially represents pre-Bishop differential uplift following deposition of the Bridger and Washakie Formations. Perhaps $150 \mathrm{~m}$ should be subtracted from the $760 \mathrm{~m}$ total to account for an initial dip of $0.2-0.4 \mathrm{~m} / \mathrm{km}$ on the Tipton, for stratigraphic transgression of the top, and for an unknown but possibly appreciable later Tertiary and Pleistocene differential uplift of the mountains. Thus, between the end of the Eocene and the deposition of the Bishop Conglomerate, the northeast flank of the Uinta Mountains may have risen some 600 $m$ relative to the centers of the adjacent basins.

Differential uplift, however, was accompanied and reinforced by regional (epeirogenic) uplift, which raised the centers of the basins as well as the mountains high enough-perhaps $900 \mathrm{~m}$ - to change the climate from the subtropical one of the middle Eocene to the more temperate climate of the post-early Oligocene, as indicated by floristic and faunal studies (Dorf, 1959; MacGinitie, 1969; Love, 1971; Leopold and MacGinitie, 1972). Nine hundred meters of regional uplift would also provide a reasonable gradient for drainage out of the Green River Basin to an ultimate base level far to the east, a gradient somewhat less than but not too different from that of the present Sweetwater and North Platte Rivers across central Wyoming. The center of the Green River Basin, therefore, may have been about $1,200 \mathrm{~m}$ above sea level when the Gilbert Peak erosion surface began to form. The mountains were more than $1,600 \mathrm{~m}$ higher, because the surface itself has $1,600 \mathrm{~m}$ or more of relief, and the peaks stand 300 $600 \mathrm{~m}$ above it. Perhaps they stood $3,000-3,700 \mathrm{~m}$ above sea level. The crestline was much degraded during Gilbert Peak and Bishop time, and the coarseness of the Bishop suggests that local relief was greater then than now.

\section{RATES OF UPLIFT}

Figures in the previous paragraph provide a means of estimating minimum uplift rates in the Lake Gosiute area between the end of the Eocene and the deposition of the Bishop Conglomerate. The maximum elapsed time was about 9 m.y., inasmuch as the Eocene ended about 38 m.y. ago, and a tuff well up in the Bishop is about $29 \mathrm{~m} . \mathrm{y}$. old, as dated by H. H. Mehnert (Hansen and others, 1981). Based on these dates and on the altitude differences of the Tipton datum before and after uplift, regional uplift in the basin exceeded $10 \mathrm{~cm}$ per thousand years $(900 \mathrm{~m} / 9 \mathrm{~m} . \mathrm{y}$.$) , and the rate of rise$ along the basin rim exceeded $16.6 \mathrm{~cm}$ per thousand years $(1,525 \mathrm{~m} / 9 \mathrm{~m} . y$.$) . The actual uplift, however,$ probably took much less than 9 m.y., perhaps half as much, because a long period of crustal and climatic stability had to follow uplift and accompany the cutting of the Gilbert Peak erosion surface to allow so broad and featureless a plain to form. This period itself probably lasted millions of years, maybe most of Oligocene time. The Rock Springs uplift, for example, had to be truncated by the Gilbert Peak erosion surface before the Bishop was deposited while, concomitantly, hundreds of square kilometers of hard rock was being bevelled along the Uinta Mountains. Reasonable rates of uplift, therefore, perhaps would have been closer to 20 $\mathrm{cm}$ per thousand years near the center of the basin and $30 \mathrm{~cm}$ per thousand years along the mountain flank. By way of contrast, the earlier rate of Laramide uplift of the Uinta Mountains was a half to a whole order of magnitude higher, in the range of $1-2 \mathrm{~m}$ per thousand years (about 9,150 m in 5-10 m.y.; Hansen, 1984, p. 15). This figure compares favorably with a calculated deformation rate for the Wind River Mountains in Wyoming-1.3 m/1,000 yrs for the displacement of the Wind River fault (Hurich and Smithson, 1982, p. $1559)$.

In the time since the Bishop Conglomerate was deposited the average rate of uplift has been very low. The center of the basin has risen about $1,100 \mathrm{~m}$ in the last 29 m.y.-about $3.8 \mathrm{~cm}$ per thousand years (or, in round numbers, $4 \mathrm{~cm}$ ). During that $29-\mathrm{m}$.y. interval the rate probably was uneven and may have varied greatly from time to time. 


\section{BROWNS PARK FORMATION}

The Browns Park Formation (fig. 13) was named for the valley of Browns Park astride the Utah-Colorado State line, where it is widespread and is exceptionally well exposed (Powell, 1876, p. 44, 186). From Browns Park it extends like a blanket east and south to Elk Springs and southeast into the Maybell-Lay-Axial Basin area, retaining a thickness of more than $490 \mathrm{~m}$ (Dyni, 1968; McKay and Bergin, 1974). Since Powell's time it has been described in considerable detail in many published reports, partly because it has been host to commercial uranium deposits.

The Browns Park Formation seems to have begun to accumulate in some places soon after the Bishop Conglomerate was deposited, perhaps with no great stratigraphic hiatus; the evidence is inconclusive. In most places, however, millions of years intervened. The region was in the midst of tectonic deformation, and sediments were accumulating in favorable locations while rock was being eroded nearby. The lithology of the formation, therefore, is varied (Luft and Thoen, 1981), but it consists chiefly of light-colored to nearly white, loosely cemented, generally calcareous sandstone and light-gray to white, vitric and ashy to earthy, friable to firm, rhyolitic tuff. Locally the sandstone is tan, has a pale greenish cast, or is rusty brown. Some of the sandstone is tuffaceous, and some of the tuff is sandy. Eastward from the Lay-Maybell area the appearance changes, and the formation more resembles the North Park Formation or the Troublesome than typical Browns Park.

Much of the sandstone in the more easterly area is eolian (fig. 18) and is intensely cross-stratified, especially in the area between Elk Springs and Maybell (Dyni, 1968, 1980; McKay and Bergin, 1974; Honey and Izett, in press). The source of the sand is undetermined, but deflation of nearby loose, sandy, upper parts of the Bishop is a likely possibility. The Bishop at that time was more widespread than it is now.

In the west, much of the sandstone in the Browns Park is cross-laminated or is obscurely bedded and appears to be fluvial. Some of it is too friable to be called rock; it is easily crushed between the fingers and would be called soil or overburden by engineers. Tuff is abundant in the western part of the area, particularly from Vermillion Creek west into Utah. There, more than 35 percent of the material in measured sections has been identified as tuff or tuffaceous sandstone (Hansen, 1965, fig. 40). The formation also contains bedded chert in its lower part near Vermillion Creek and East Boone



Figure 18.-Eolian crossbedding in Browns Park Formation near U.S. Highway 40 a few kilometers west of Maybell, Colo. Tangentially bedded upper set rests on a planar truncation surface on the lower set. Exposure is about $3 \mathrm{~m}$ high. Viewed toward the northwest. 
Draw; it contains minor amounts of limestone, especially in the Douglas Draw-Smelter Hill area south of Greystone, some of which is oolitic; it contains siltstone and lacustrine clay; and, in the western part of Browns Park, it has abundant locally derived conglomerate at varied stratigraphic levels. All these rock types are mentioned to highlight the lithologic differences between the Browns Park Formation and the Bishop Conglomerate.

In the western Browns Park area and just to the west in Red Canyon, the formation has greater lithologic diversity than elsewhere, mostly because of a varied depositional environment engendered by strong topographic relief. I regard patches of wellcemented sandstone and conglomerate along and below the rims of Red Canyon as remnants of alluvial fans. Most of the constituent material was derived from the Uinta Mountain Group, and the resulting deposits range from fine-grained sandstone to heterogeneous bouldery conglomerate, of which the larger boulders exceed $3 \mathrm{~m}$ in diameter. In the Dutch John area, sandstone and conglomerate interfinger with tuff. The overall color of the Browns Park at Red Canyon is tawny to light gray, exemplified by large exposures near the right (south) abutment of Flaming Gorge Dam. It contrasts, therefore, with the somber reds of the adjacent Uinta Mountain Group. Although some clasts retain the red color of the parent Uinta Mountain Group, most of them are partly bleached or mottled. Some have bleached shells covering fresh red cores. Calcium carbonate is the chief cementing material, but some sandstone is cemented with silica.

The tuffs are of two general types, vitric and earthy. Some of the vitric ones are well bedded or crossbedded, and some even contain climbing ripples that suggest rapid sedimentation in standing water (fig. 19). Others appear to have been reworked by winds into eolian crossbeds. Many tuffs, though, are massive or only faintly laminated; these perhaps settled quietly from still air. All the vitric tuffs have low bulk densities. The earthy tuffs are mostly well bedded, commonly having laminations that look lacustrine (fig. 19). Such a mode of deposition would facilitate alteration of the glass to produce the earthy texture. Some beds have load casts, ball-and-pillow structures, contortions, and broken, disrupted laminations of a sort that should form in standing water. As much as 20 percent of the material in several measured sections is lacustrine clay (Hansen, 1965, fig. 40), some of which contains diatoms and sparse ostracods.

The source of the tuffs is unknown; explosive volcanic activity was widespread in the Western United States in Miocene time (Izett, 1968; Marvin and others, 1970; Christiansen and Lipman, 1972). Most of the nonvol- canic material in the valley of Browns Park was locally derived. Broad fans, consisting chiefly of pebbly cobbly alluvium derived from the Uinta Mountain Group but including Paleozoic limestone and older Precambrian metamorphic rocks, spread intermittently from the highlands enclosing Browns Park. The fans were buried from time to time by falls of volcanic ash, some of which was reworked into tuffaceous sandstone. Periodically, much of Browns Park was flooded by lake waters that deposited blankets of sand and clay. The result is a complex interbedding of conglomerate, sand, tuff, and clay. The tuffs and clays retain remarkable uniformity over considerable distances, but the sands and conglomerate thin from the sides toward the axis of the valley (Hansen, 1957a). Parts of the section were exposed to erosion at times, but for how long is unknown. Although unconformities have been recognized within the Browns Park Formation (Sears, 1924a, p. 296; Ritzma, 1965b, p. 131; Hansen, 1965, measured sections), their significance is undetermined. Sears noted an angular discordance near the east end of Browns Park.

Boulders of unusual size, some more than $5 \mathrm{~m}$ in diameter, occur in the Browns Park Formation at and near the SW corner sec. 21, T. 2 N., R. 24 E., near the head of the valley of Browns Park. There the formation fills a steep-sided channel cut into the Uinta Mountain Group just north of the existing trench of the Green River. These deposits pass into finer grained conglomerate which, in turn, interfingers with tuffaceous sandstone (Hansen, 1965, p. 118).

\section{POST-BISHOP, PRE-BROWNS PARK CHANGE IN DRAINAGE DIRECTION}

Other fanglomerates in the Browns Park Formation near the head of Browns Park thicken and coarsen markedly from the center of the valley toward the north margin and thus provide clear evidence of their source and direction of transport. Red quartzite from the Uinta Mountain Group is the chief constituent and, on lithologic grounds only, could have come from any direction, but abundant pebbles of white metaquartzite, amphibolite, and other rock types from the Red Creek Quartzite and occasional pebbles of gray Paleozoic limestone must have had sources to the north (Hansen, 1965 , p. 118, 173). The Red Creek material obviously came from nearby areas just north of Browns Park. The limestone pebbles probably were recycled out of conglomeratic beds in the Wasatch Formation, also to the north, because all the Paleozoic limestone in that part of the Uinta Mountains had been removed by postWasatch erosion and pre-Browns Park movements on the Uinta fault. The Wasatch, therefore, is the only likely source, and the nearest Wasatch outcrops are 

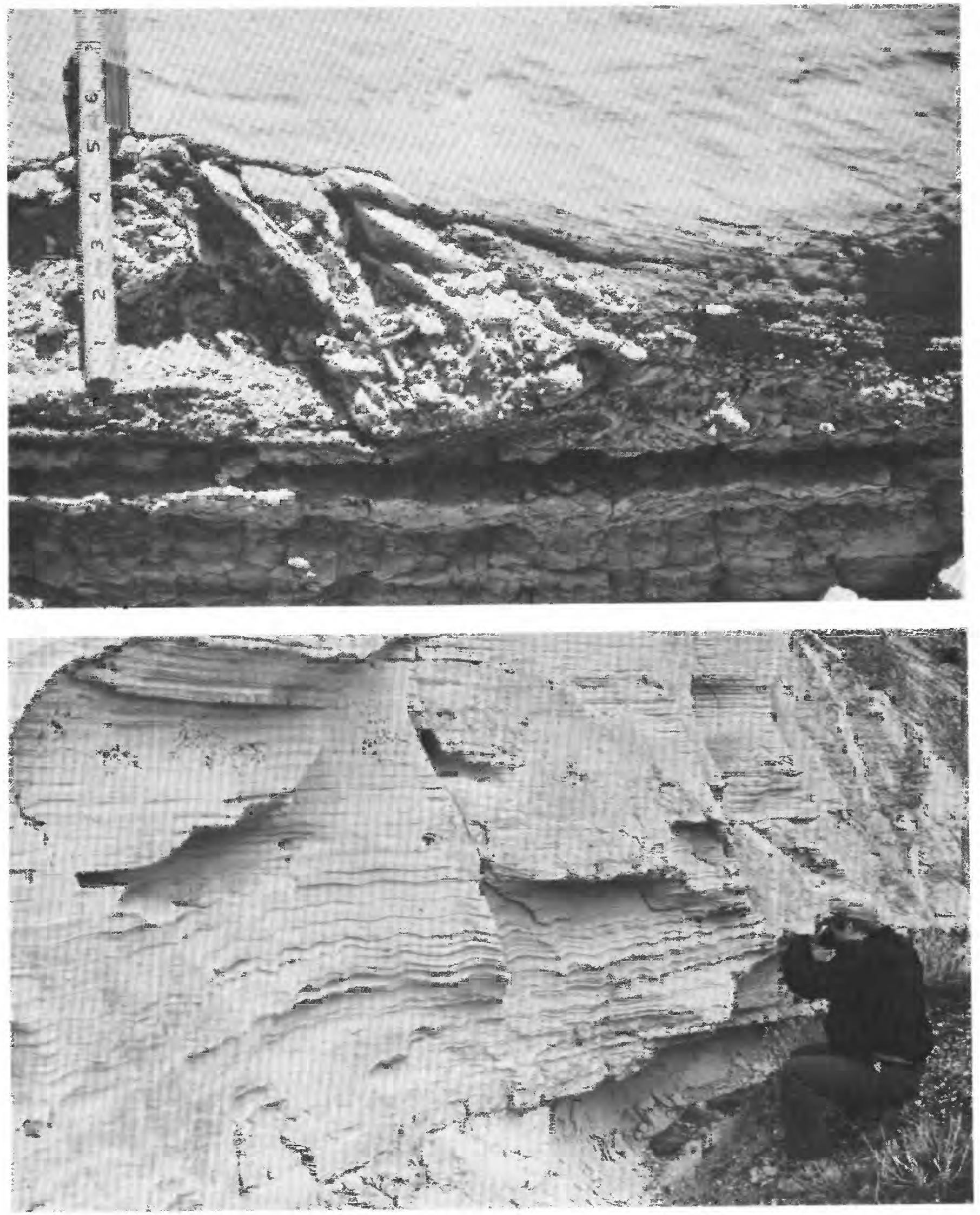
north of Browns Park near the Wyoming State line. Some cobbles might have been reworked from Bishop Conglomerate, but it, too, lay to the north. Thus, the direction of drainage across the area was reversed after the Bishop Conglomerate was deposited from the south and before the Browns Park was deposited from the north. The reversal was caused by regional tilting, described in detail later. The tilting and the drainage reversal required a significant interval of time after the Bishop was deposited and before the Browns Park Formation was deposited.

\section{AGE OF THE BROWNS PARK FORMATION}

Radiometric and fission-track datings indicate a wide age span for the Browns Park Formation in the Eastern Uinta Mountains region. The oldest date so far measured, $24.8 \pm 0.8 \mathrm{~m}$.y., is a potassium-argon age obtained from a biotite separate of chalky white tuff collected by Izett and others (1970; Izett, 1975) from the northwest side of the Little Snake River, about $30 \mathrm{~m}$ above the top of the Bishop Conglomerate, and hence very close to the base of the Browns Park Formation. This tuff is about $4 \mathrm{~m}$.y. younger than the tuff in the Bishop Conglomerate on the Diamond Mountain Plateau and is approximately equivalent in age with the lowermost Arikaree Formation of the Great Plains and the Wyoming Basin. A much younger zircon fissiontrack age of $9.9 \pm 0.4 \mathrm{~m} . \mathrm{y}$. was obtained by Naeser and others $(1980$, p. 24$)$ from vitric tuff higher in the section at Vermillion Creek. Damon (1970, p. 52) determined a potassium-argon age of $11.8 \pm 0.4 \mathrm{~m} . \mathrm{y}$. for glass from a vitric tuff collected by G. R. Winkler in Browns Park in Utah. These ages thus span about 15 m.y., the latter two being equivalent with part of the Ogallala Formation of the Great Plains. Honey and Izett (in press) have recently reported an additional age of $11.3 \pm 0.8$ m.y.from a site between Maybell and Cross Mountain. Whether or not deposition was continuous throughout that time is unknown, but local unconformities suggest episodic pauses of undetermined length. Physiographic constraints, discussed further below, argue against rocks much older than 12-15 m.y. existing in the Browns Park Formation within the valley of Browns Park.

Figure 19.-Water-laid tuffs in the Browns Park Formation near Dutch John, Utah (in measured section B-2 of Hansen, 1965, p. 121).

Top.-Well-stratified, earthy tuffs overlain unconformably by massive, vitric airfall tuff. Scale is in inches $(1 \mathrm{in.}=2.54 \mathrm{~cm})$.

Bottom.-Climbing ripples, laminae in phase, suggest heavy suspended load and rapid sedimentation in gently oscillating water.

\section{BISHOP CONGLOMERATE BENEATH THE BROWNS PARK FORMATION IN THE ELK SPRINGS-MAYBELL AREA}

In many places east of the Uinta Mountains a thick, loosely cemented conglomerate, here assigned to the Bishop, lies at the base of the Browns Park Formation. The existence of this rock has led to most of the speculation regarding the relationship of the Browns Park to the Bishop. This speculation arose, perhaps, out of the widely held assumption that the conglomerate is merely the basal unit of the Browns Park Formation. Sears' early conclusion (1924a) that the Bishop and the basal Browns Park are one and the same was subsequently challenged by Bradley (1936). This conglomerate has not generally been shown separately on maps, nor has it received close scrutiny in the literature; its detailed distribution and its relation to the Browns Park have largely escaped serious study. McKay (1974) assigned it to the Browns Park Formation but noted its significant lateral differences and mapped its outcrop separately for about $19 \mathrm{~km}$ west of the Little Snake River. Dyni (1980) described it in some detail but did not differentiate it on the map; most other workers in the area did neither.

Evidence now indicates that two separate and distinct conglomerates underlie the Browns Park Formation in the area east from Vermillion Creek to the limit of outcrop east of Maybell. One is indeed a basal conglomerate, and it passes upward gradationally into the overlying beds (Hancock, 1925, p. 24). The other, I believe, is the Bishop, disconformable with the Browns Park and genetically unrelated.

Sears (1924b, p. 295) actually touched close to the heart of the problem when, in describing the Browns Park Formation, he noted that "almost everywhere the base of the formation is marked by a conglomerate, which has very different characteristics in the eastern and western parts of the field." From Simsberry Draw (which is just east of the Little Snake River; fig. 13) east toward Juniper Mountain, the basal conglomerate of the Browns Park Formation is less than $1 \mathrm{~m}$ thick and has a light-gray overall tint. North of Sunbeam it is locally nonexistent. Just east of Juniper Mountain, near the Yampa River, it reaches about $15 \mathrm{~m}$ (Hancock, 1915, p. 186). East from Simsberry Draw to Juniper Mountain, it consists of small subrounded to subangular pebbles of mafic and felsic igneous and metamorphic rocks, red and white quartzite, varicolored chert, and milky quartz (McKay, 1974; McKay and Bergin, 1974; Sears, 1924b, p. 295). Its lithology indicates a Park Range provenance (Izett, 1975, p. 203; oral commun., 1975). 
From the Little Snake River west toward Vermillion Creek, however, the conglomerate changes abruptly in thickness, color, and lithology to an aspect much the same as that of the classic Bishop Conglomerate: "in appearance the two conglomerates are practically identical" (Sears, 1924b, p. 289). Tracing it from the Little Snake River to Vermillion Creek, Sears (1924a, p. 295; $1924 \mathrm{~b}$, p. 285) reported a maximum thickness of $90 \mathrm{~m}$. McKay (1974) reported $15-90 \mathrm{~m}$. The average might be near $45 \mathrm{~m}$. Locally, however, it is nonexistent-removed, I believe, by pre-Browns Park erosion. As seen at Sand Wash, it is a poorly sorted cobbly conglomerate that contains abundant boulders of red quartzite and gray limestone, some more than a meter in diameter, mostly some distance above the base, and clearly derived from the Uinta Mountains. Its overall color is pink. Its dip is southwesterly. At the Little Snake River, where it appears to be partly eroded, it is not as coarse or as thick as at Sand Wash, but there also its provenance is the Uinta Mountains, and it retains the overall pink color.

On the southeast side of the Yampa valley, between Elk Springs and Maybell, across the Browns Park-Lay syncline, the conglomerate reemerges from beneath the Browns Park Formation and forms a line of rolling hills on and flanking Elk Springs Ridge. There it has a northerly dip of several degrees. There, too, the provenance is clearly the Uinta Mountains, although the dip is toward the Uintas. Cobbles and small boulders of gray limestone predominate, but red quartzite is abundant, and gray chert is common. Notably lacking are igneous and metamorphic crystalline rocks from the Park Range. The assemblage is typical Uinta Mountains material, and the texture is much coarser than that of the Park Range derivatives at the base of the Browns Park Formation to the east and northeast. At Elk Springs the conglomerate is very well exposed in a large gravel pit just south of U.S. Highway 40 , where it has a dip of about 20 degrees north.

West from Elk Springs, as the conglomerate emerges from beneath the white eolian sandstone of the Browns Park Formation, it flattens rapidly, then rises gradually westward. To the north the conglomerate slopes gently into the Lily Park syncline (Dyni, 1968). Although mapped as Browns Park Formation west and north of Elk Springs (Schultz, 1918, pl. 5; Sears, 1924b, p. 291; Dyni, 1968, 1980; McKay, 1974), it has the appearance of the Bishop conglomerate where it emerges from beneath the Browns Park sandstones. To the west it caps flat-topped remnants of a once broader surface that merges farther west with the high Gilbert Peak erosion surface of the south flank of the Uinta Mountains.

\section{CRITICAL RELATIONSHIP OF THE BROWNS PARK FORMATION TO THE BISHOP CONGLOMERATE NEAR LILY PARK}

Although there are thus two distinctly different conglomerates at the base of the Browns Park Formation east of the Uinta Mountains, they are not of themselves wholly incompatible with Sears' early view (1924a) that the Bishop Conglomerate is the basal conglomerate of the Browns Park Formation. Exposures in the Lily Park area, however, especially in the canyon of the Little Snake River between the east end of the Uinta Mountains and Cross Mountain, demonstrate the topographic and sedimentological discontinuity between the Bishop Conglomerate and the Browns Park Formation.

West and south of Cross Mountain, at Klauson Pasture, Horse Gulch (on the west flank of Cross Mountain), and Twelvemile Mesa, thick terrace deposits of conglomerate stand high above the valleys of the Little Snake and Yampa Rivers, lapping across the older formations (fig. 20; see also fig. 9 , bottom). These deposits have been referred to by earlier investigators as the lower conglomerate unit of the Browns Park Formation, but they are here regarded as Bishop. The conglomerate cap at Twelvemile Mesa merges to the south with the conglomerate of Elk Springs Ridge, which in turn merges westward with the remnants that P. D. Rowley, P. E. Carrara, and I mapped as Bishop Conglomerate along the south flank of the Uinta Mountains (Rowley and others, 1979). The deposits on Twelvemile Mesa and Klauson Pasture have the typical Uinta Mountains lithologic affinities and are practically identical; the Horse Gulch deposit is largely local material derived from the slopes of Cross Mountain, but all three deposits are clearly correlative geomorphically and must have once have been a continuous body of gravel resting on one surface.

This surface, restored, has a northerly component of slope caused by postdepositional tilt. Near the north end of Cross Mountain it ends as a terrace, although it once may have continued north some distance beneath the Browns Park Formation, just as it still does to the south at Elk Springs. Field evidence on that point is unclear. However-and this relationship is critical-the Browns Park Formation extends tongue-like down the canyon of the Little Snake River at a level lower than the outcropping conglomerate, to and beyond the point where Klauson Pasture and the bench at Horse Gulch project toward one another (fig. 21). Beneath the sandstones of the Browns Park Formation at that point, a well-stratified, horizontally bedded basal conglomerate about $5 \mathrm{~m}$ thick rests on a bedrock terrace cut on the Glen Canyon Sandstone about $50 \mathrm{~m}$ 


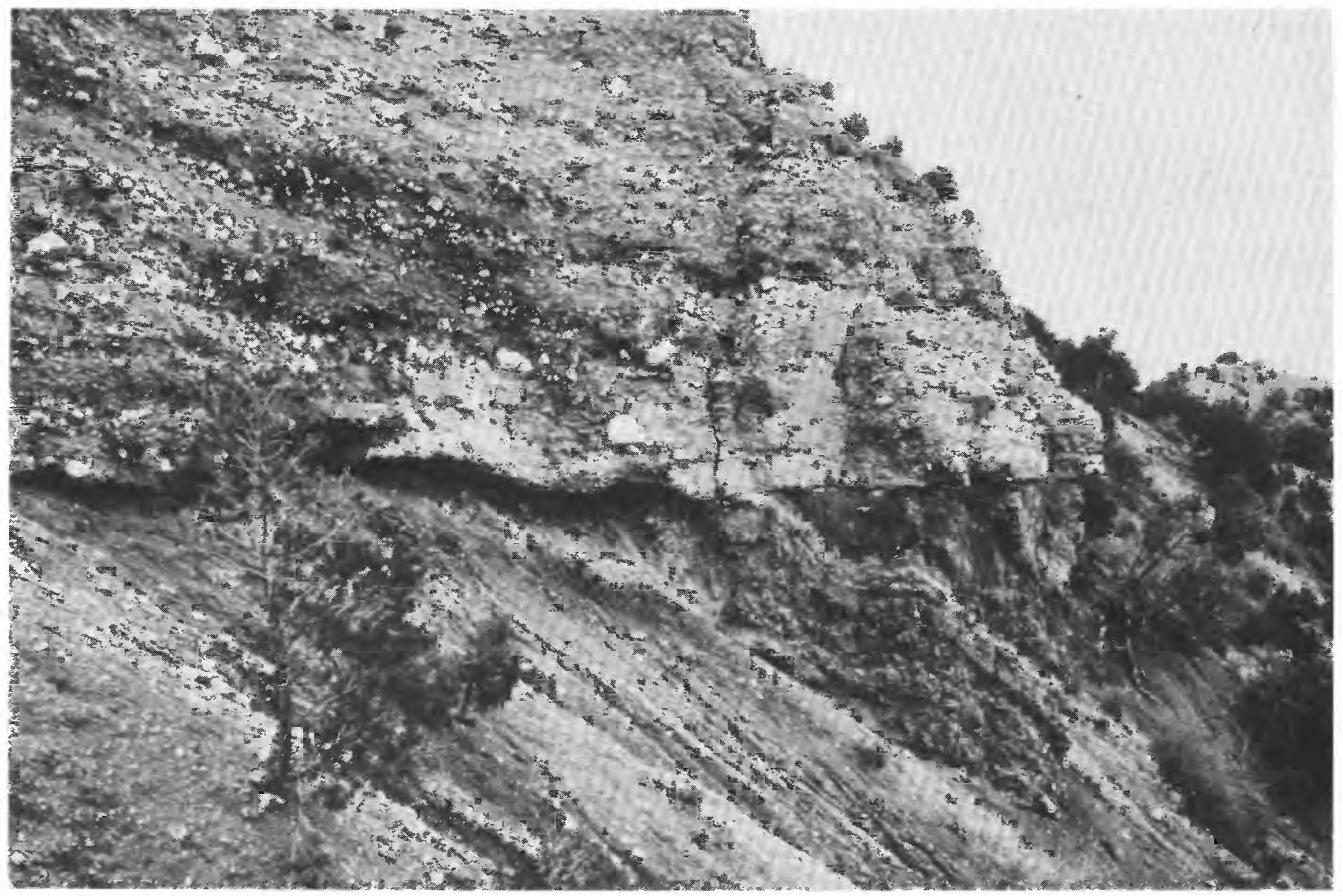

FigURE 20.-Poorly sorted, poorly bedded Bishop Conglomerate resting unconformably on truncated Morrison Formation, west flank of Cross Mountain, Moffat County, Colo., about $120 \mathrm{~m}$ above valley floor. This sequence was considered by earlier investigators to be the basal conglomerate of the Browns Park Formation. Boulder at center of photograph is $60 \mathrm{~cm}$ across. Compare with figure 22 .

above the river (fig. 22). This relationship is well exposed at Wild Cow Draw, $3 \mathrm{~km}$ downstream from the bridge and gaging station at the head of the Little Snake canyon. There, the basal conglomerate is mostly subangular pebbles and small cobbles embedded in a well-cemented matrix of poorly sorted sandstone. The clasts are mostly red quartzite and gray limestone derived from the adjacent mountains. This conglomerate is unlike the nearby Bishop, and there can be no mistaking its separate identity. The Bishop here is $60 \mathrm{~m}$ thick, caps benches $180 \mathrm{~m}$ or more above the valley floor, and differs from the basal Browns Park in thickness, bedding habit, stratigraphic position, and topographic setting. The Bishop is less well sorted, and its bedding is less uniform. One can only conclude that the Browns Park Formation was deposited in the valley long after the conglomerate on Klauson Pasture and on the bench at Horse Gulch was parted by erosion.

Twelvemile Mesa correlates geomorphically across the Yampa River with Klauson Pasture (Dyni, 1980), and the capping conglomerates on these surfaces are
WEST

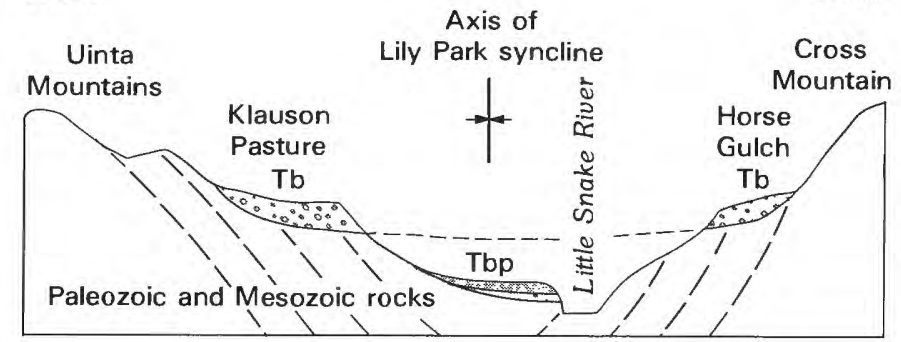

FIGURE 21. Sketch section across canyon of Little Snake River at Lily Park syncline, showing relationship of Bishop Conglomerate (Tb) to Browns Park Formation (Tbp). Section is about $61 / 2 \mathrm{~km}$ across. Vertical scale is greatly exaggerated.

virtually identical. But the deposit on Twelvemile Mesa passes beneath the Browns Park Formation to the east and south, further proving that the Browns Park is stratigraphically higher and younger. According to J. R. Dyni (oral commun., 1981) the conglomerate beneath the Browns Park on Twelvemile Mesa is discontinuous. Dyni (1980) suspected pre-Browns Park (pre-"upper 


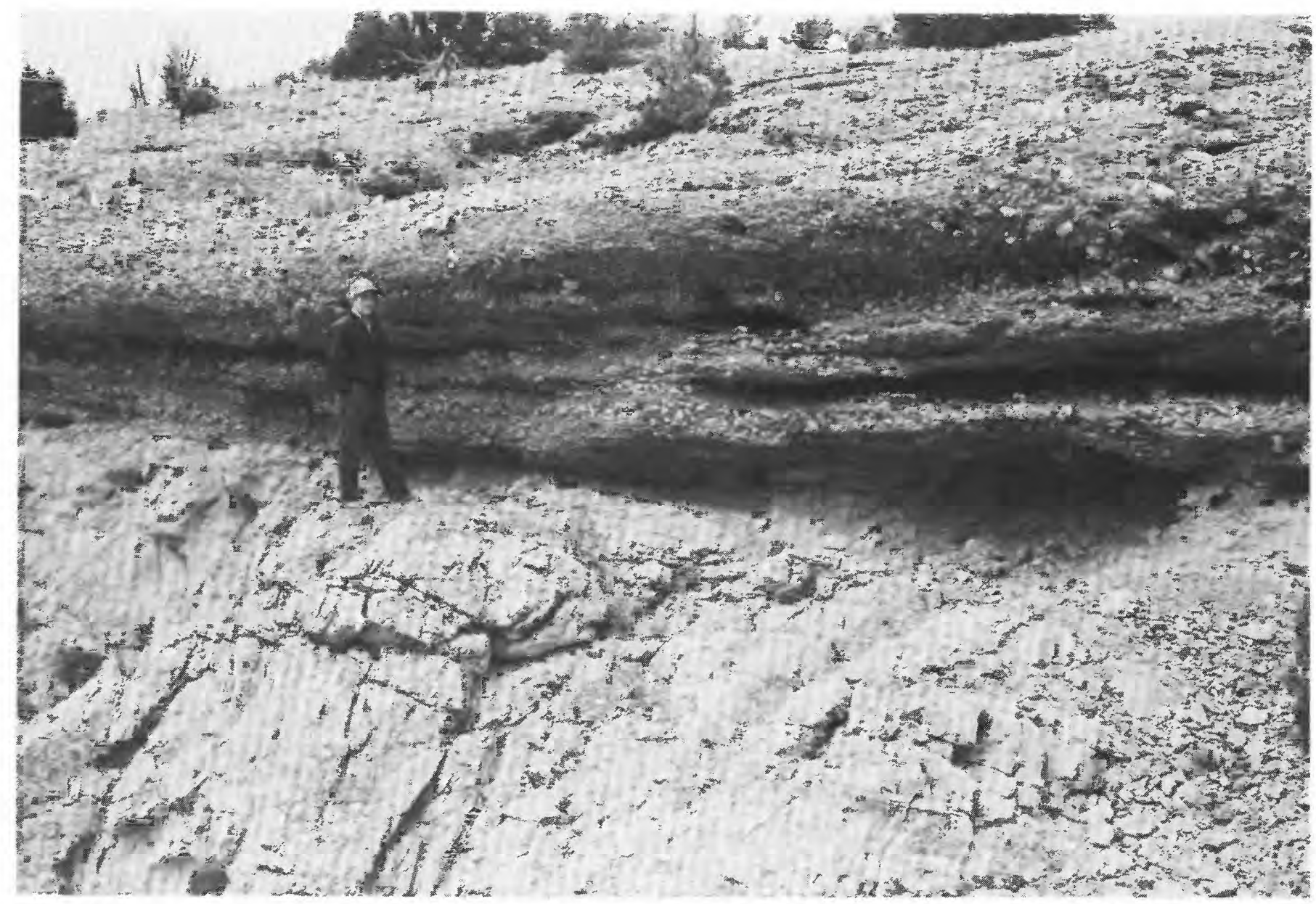

FIGURE 22.-Basal conglomerate of the Browns Park Formation resting unconformably on truncated Glen Canyon Sandstone, in the canyon of the Little Snake River at the east end of the Uinta Mountains. Pebbles and small cobbles are embedded in a matrix of well-cemented, poorly sorted, coarse-grained sandstone. Exposure is about $50 \mathrm{~m}$ above river level. Compare with figure 20.

sandstone unit") folding in the conglomerate. It seems clear that the conglomerate on Twelvemile Mesa, as well as on Klauson Pasture, was deformed and dissected before the Browns Park Formation was deposited. In the broad downwarp between Vermillion Creek and Maybell, however, where the Bishop was lowered enough tectonically for subsequent burial, the Browns Park was deposited directly on it. Elsewhere the Browns Park lies in valleys tens to hundreds of meters lower than nearby remnants of Bishop Conglomerate.

\section{RANDOM RELATIONSHIP OF THE BROWNS PARK FORMATION TO THE GILBERT PEAK EROSION SURFACE}

Bradley (1936) was first to evaluate the relationship of the Browns Park Formation to the Gilbert Peak erosion surface, largely refuting the earlier conclusions of Sears (1924a), who later acceded to Bradley's view. As will be shown, this relationship provides further evi- dence of the disparate ages of the Browns Park Formation and the Bishop Conglomerate. It now appears that Sears was correct in identifying as Bishop the conglomerate beneath the Browns Park Formation in the Dry Mountain-Sand Wash-Little Snake River area but was incorrect in concluding that it also was a basal conglomerate of the Browns Park.

Bradley (1936) did not believe that the conglomerate beneath the Browns Park Formation was the Bishop, nor that the underlying pediment was the Gilbert Peak surface. Specifically, he believed that the pediment remnant preserved on Bear Mountain was part of a regional erosion surface (the "Bear Mountain erosion surface") which passed eastward beneath Browns Park and was lower and distinctly younger than the Gilbert Peak surface. He also supposed that the Browns Park Formation was deposited on this surface shortly after the surface formed, and that the conglomerate underlying the Browns Park was the basal unit of that formation. Remnants of a surface that Bradley correlated with his 
Bear Mountain surface are plentiful in the southwestern part of the Green River Basin of Wyoming; they generally lie $120-150 \mathrm{~m}$ below the Gilbert Peak erosion surface and 60-90 m above modern drainage, and they are capped with gravel but lack the covering white sand of the typical Browns Park (Bradley, 1936, p. 180 ). Bradley considered the gravel on these remnants to be a basal conglomerate of the Browns Park Formation, but such a correlation-between dissimilar deposits many kilometers apart-is tenuous in the absence of typical Browns Park material. In all probability, the gravel on those outlying remnants is Pleistocene or late Pliocene.

I regard the two surfaces-Gilbert Peak and type Bear Mountain-as one, displaced by faulting, for the following reasons:

1. In its type area, the Bear Mountain surface at Bear Mountain and Dutch John Bench is separated from the Gilbert Peak surface at Goslin Mountain by faulting.

2. Berm-like remnants or outliers of the Gilbert Peak surface might be expected to remain between Bear Mountain and the crest of the range if the Bear Mountain surface were younger and lower than the Gilbert Peak surface.

3. The Bear Mountain surface as mapped by Bradley is everywhere capped by younger deposits, except at the type locality, where it and the adjacent Gilbert Peak surface are both bare bedrock.

4. The type Bear Mountain surface rises and merges gradually westward with the type Gilbert Peak surface (Bradley, 1936, fig. 16).

5. At Red Canyon, the type Bear Mountain surface is $360-550 \mathrm{~m}$ above modern drainage and stands tens to hundreds of meters above remnants of the Browns Park Formation, which fill swales and valleys cut into the surface. Gravel-capped remnants that Bradley correlated with the surface in southwestern Wyoming are only $60-90 \mathrm{~m}$ above modern drainage. The type surface was deeply dissected before the Browns Park Formation was deposited, and a long period of time, therefore, intervened.

6. The type Bear Mountain surface, like the Gilbert Peak surface, projects high above the head of Browns Park, rather than passing beneath it as Bradley supposed.

7. Time constraints argue against the development of a local but broad surface cut into hard rock and intermediate in age between the Bishop Conglomerate and the Browns Park Formation. A long time interval had to elapse (a) during pedimentation, (b) during subsequent dissection of the pediment, and (c) before deposition of the Browns Park Formation across the dissected topography.
8. There is only one extensive subsummit pediment in the Eastern Uinta Mountains, just as there is only one elsewhere in the Southern Rocky Mountains of Colorado (Epis and Chapin, 1975; Epis and others, 1980).

The random relationship of the Browns Park Formation to the Gilbert Peak surface is even more evident in the valley of Browns Park (fig. 23). There the Gilbert Peak erosion surface forms the broad summits of the several high mesas (Goslin Mountain, Mountain Home in part, Head of Cottonwood, Bender Mountain in part, O-Wi-Yu-Kuts Mountain, and Cold Spring Mountain; all on fig. 27) that border the valley and stand 300-600 $\mathrm{m}$ above the valley floor. Filling the valley bottom, the Browns Park Formation laps against the lower slopes and spurs of these mesas in depositional contact with the Uinta Mountain Group (into which the mesas and the valley subfloor are carved) and extends into side valleys cut by post-Gilbert Peak erosion. The contact of the Browns Park Formation with the Uinta Mountain Group is discontinuously faulted along the northeast side of the valley by post-Browns Park movements on older faults (Hansen, 1965, plate 1; also fig. 27, this report), but the old hard-rock floor of the valley was formed chiefly by erosion along the axis of the Uinta anticline long after the Gilbert Peak erosion surface had formed. Later valley erosion was guided by warping and faulting before deposition of the Browns Park Formation.

In many places along the north side of Browns Park the Gilbert Peak erosion surface is tilted southward toward the valley, opposite its original slope. This tilting created new south-flowing drainages. Earlier, when the Bishop Conglomerate was accumulating, the site of Browns Park must have been a mountainous source of detritus for the conglomerate now exposed in the broad area to the north. The Gilbert Peak surface stretched northward from these mountains. The reversal of topography came later, following pedimentation, faulting, and foundering of the Uinta arch, before the Browns Park Formation was deposited, and the resulting trough provided a natural stilling basin for the accumulation and preservation of the gravels, sands, tuffs, and clays of the Browns Park Formation (Hansen, 1965, p. 129-130).

The extent of faulting beneath Browns Park is obscured by the Browns Park Formation and hence is unknown, but it probably is considerable, if the abundance of faults in the valley margin is indicative. Some of these faults cut the Browns Park Formation, but most of them pass beneath it. The course of drainage through Browns Park surely was influenced by such faults. A drainage line controlled initially by a fault line need not coincide with the present trace of the fault if the fault has an appreciable dip. As the land surface 
Miller Mountain

1

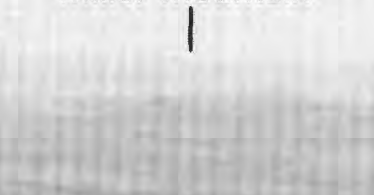

C O L D
Pine Mountain

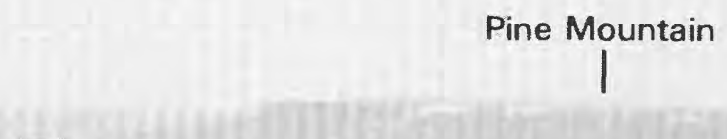

UINTA

S P R ING
FAULT

MOUIAIN

Figure 23.-Aerial view over Browns Park looking north across the Gilbert Peak erosion surface on Cold Spring Mountain, in middle distance, toward Pine (Bishop) Mountain, flecked with snow drifts on skyline. Browns Park Formation in the foreground, $760 \mathrm{~m}$ below top of Cold Spring Mountain, is in depositional contact with the Uinta Mountain Group. Note how the Browns Park Formation extends into Spitzie Draw, indicating that the draw-which obviously is younger than the Gilbert Peak erosion surface-is older than the Browns Park Formation, though modified by post-Browns Park erosion. Pine Mountain on the skyline is capped with Bishop Conglomerate (the type locality). The Uinta fault passes between Pine Mountain and Cold Spring Mountain. 


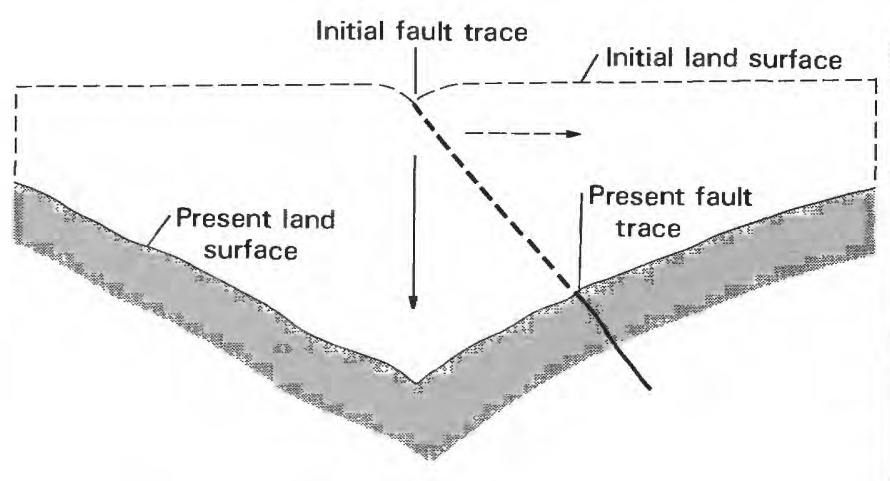

FIGURE 24.-Diagram showing how the trace of a dipping fault that initially controlled the position of a drainage line can shift away from that line during degradation. As the drainage cuts vertically downward (solid arrow) the fault trace shifts laterally (dashed arrow).

is lowered by degradation, the fault trace shifts laterally, whereas the drainage is prone to cut vertically downward (fig. 24). Examples of this principle are common in the West.

Although Bradley (1936, fig. 16) had thought it flat, the hard-rock subfloor of the old Browns Park valley apparently is canyonlike. In general its deepest part is well north of the present valley bottom, probably near the axis of the Browns Park syncline, which formed partly by differential compaction of the thick sedimentary prism. At Swallow Canyon the Green River now impinges on the south wall of the old valley, forming a superimposed trench cut into the Uinta Mountain Group through a once-buried spur-Kings Point-which has been exhumed and incised. The summit of the spur, $200 \mathrm{~m}$ above the river, must have once been covered by the Browns Park Formation. The buried axis of the old valley lies far to the north.

Just north of the Gates of Lodore, outcrops of the Uinta Mountain group limit the position of the old valley bottom to a zone less than $2.4 \mathrm{~km}$ wide. There the present valley bottom has an elevation of about 1,630 $\mathrm{m}$, but drill-hole data indicate that the hard-rock floor just to the north is at least $180 \mathrm{~m}$ deeper (S. J. Luft, U.S. Geological Survey, written commun., 1980). The buried-valley profile north of the Gates must have sloping sides of at least 10-12 degrees.

It thus is evident that the Browns Park Formation, unlike the Bishop Conglomerate, had no genetic relationship to regional pedimentation in the eastern Uinta Mountains in general or to the Gilbert Peak sur- face in particular. The Browns Park Formation filled valleys narrow and wide, buried hills and spurs of mountains, and spread out locally over broad areas. In the Boone Draw-Maybell-Lay area, it was deposited across the Bishop Conglomerate after the conglomerate and the subjacent Gilbert Peak erosion surface both had been partly dissected and had been greatly depressed by pre-Browns Park regional warping; locally, the Bishop was completely removed before the Browns Park was deposited. In the lowest part of its old valley, between Simsberry Draw and Juniper Mountain (fig. 13), the Browns Park has its own basal conglomerate of material carried out of the Park Range by an ancestral drainage of the Yampa valley. On the other hand, where the Bishop remained above the general depositional level, the Browns Park Formation accumulated in depressions topographically lower than the Bishop, some much lower.

I know of only one locality in the eastern Uinta Mountains where the Browns Park Formation rests with apparent conformity on a well-defined but local remnant of a pediment. That locality is in Moffat County just north of Irish Canyon (fig. 42) in T. 10-11 N., R. 101 W. Both Sears (1924a, p. 292) and Bradley (1936, p. 181-182) described it in some detail because of its relationship to Cold Spring Mountain and the Uinta-Sparks fault zone. Bradley used this relationship to refute the equivalence of the Bishop Conglomerate and the basal conglomerate of the Browns Park Formation. A berm-like remnant of a pediment, which Bradley identified as the Bear Mountain surface, cuts into the flank of Cold Spring Mountain about $300 \mathrm{~m}$ below the summit. The berm is capped with a cobbly conglomerate, about $15 \mathrm{~m}$ thick, made mostly of limestone cobbles and occasional small boulders in a coarse, poorly sorted sandstone matrix. The limestone plainly came from the nearby outcrops of Limestone Ridge along the north side of Cold Spring Mountain. Cobbles of red quartzite from the Uinta Mountains Group are subordinate-just a few percent. The conglomerate passes beneath typical white sandstone of the Browns Park Formation and slopes eastward toward Vermillion Creek. Although Sears correlated this conglomerate with the Bishop, it differs markedly from nearby Bishop Conglomerate in thickness, lithology, and texture, and is, in fact, a local basal facies of the Browns Park Formation. On nearby Pine Mountain and Diamond Peak the Bishop stands $600 \mathrm{~m}$ higher, is nearly $60 \mathrm{~m}$ thick (Roehler, 1972a, b), and consists mostly of red quartzite clasts, some very large. 


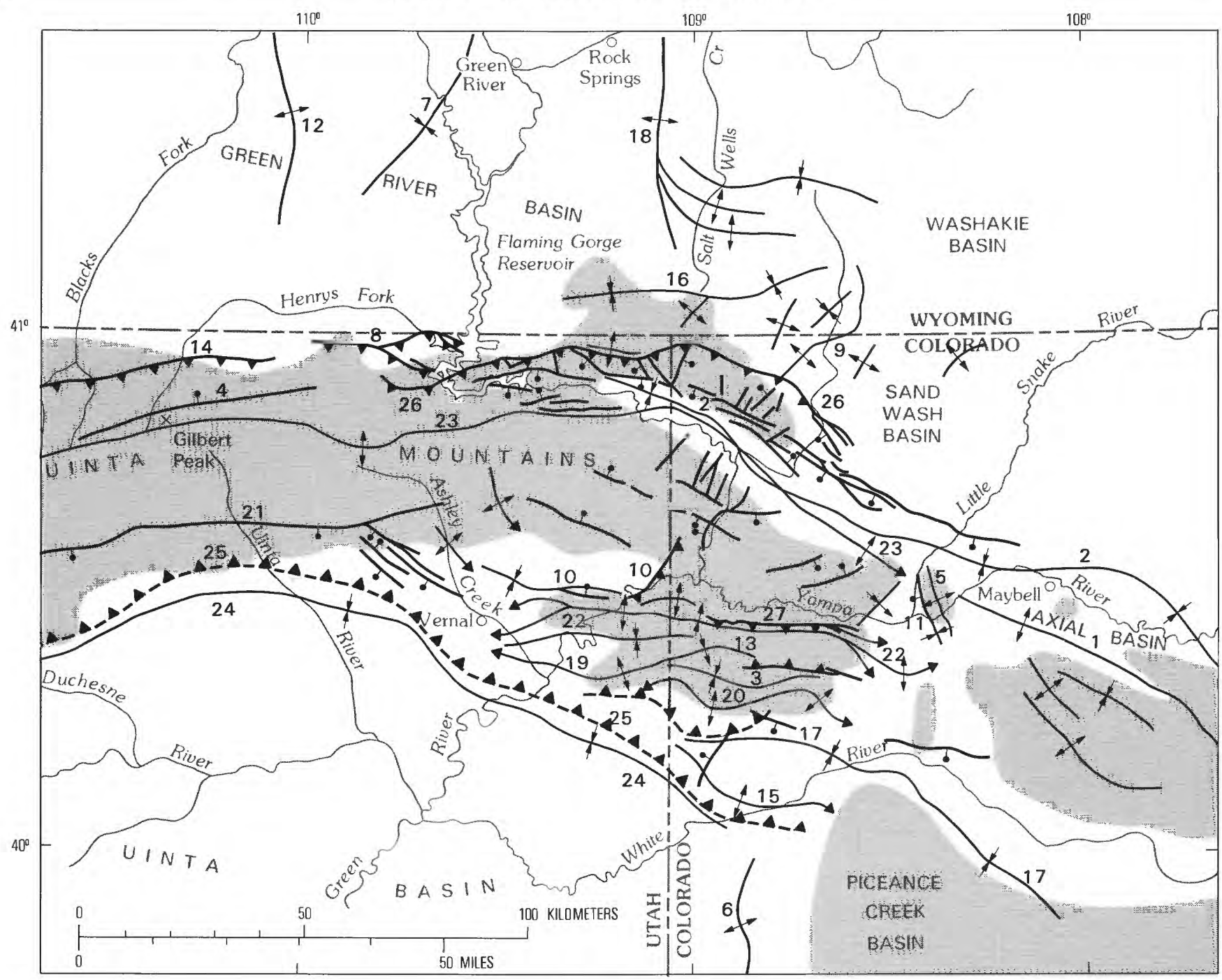

EXPLANATION



1. Axial Basin anticline

2. Browns Park-Lay syncline

3. Buckwater Ridge syncline

4. Crest fault

5. Cross Mountain anticline

6. Douglas Creek arch

7. Green River basin axis

8. Henrys Fork fault

9. Hiawatha anticline

10. Island Park fault/syncline

11. Lily Park syncline
12. Moxa arch

13. Mud Springs monocline

14. North flank fault

15. Rangely anticline

16. Red Creek syncline

17. Red Wash syncline

18. Rock Springs uplift

19. Section Ridge anticline

20. Skull Creek-Willow Creek anticline

21. South flank fault

22. Split Mountain-Yampa-Elk Springs anticline

23. Uinta anticline

24. Uinta Basin axis

25. Uinta Basin boundary fault

26. Uinta-Sparks fault zone

27. Yampa fault

FIGURE 25.-Generalized tectonic map of the Eastern Uinta Mountains and vicinity showing principal folds and faults. Dashed lines with sawteeth indicate the approximate positions of unexposed north-dipping thrust faults detected or inferred in the subsurface by seismic exploration and drilling (Anderman, 1961; Cullins, 1969; Ritzma, 1969). Similar concealed south-dipping thrust faults may border the range on the north (Clement, 1977; Gries, 1981). Symbol (D) beside fault indicates downthrow of second movement. 


\section{DEFORMATION}

The principal structural features of the Eastern Uinta Mountains and adjacent areas are ploted on figure 25. The mountains first arose in latest Cretaceous time when the old Western Interior seaway drained for the last time. Tectonic events since that time, and corresponding geomorphic and sedimentologic events, are summarized in table 2 . In a study of the sedimentary history of the Uinta Basin, Ryder and others (1976, p. 510) noted deformation of the Cretaceous coastal plain and closure of the Uinta Basin in latest Cretaceous time, accompanied by the rise of the Uinta Mountains. The easternmost Uinta Mountains region apparently was structurally low as late as Maastrichtian time, inasmuch as marine Lewis Shale has been recognized in the No. 1 Raeder-Government test well drilled on the Dry Mountain anticline in sec. 29, T. 9 N., R. 99 W., Moffat County, Colo. (Ritzma, 1965b, p. 135). The western part of the range began to rise earlier, when the Maastrichtian, orogenic Currant Creek Formation (of Walton, 1944) was deposited on the early Campanian, pre-orogenic Mesaverde Formation (Walton, 1944, p. 126). According to Bruce Bryant (written commun., 1983), the Currant Creek contains clasts from the Uinta Mountain Group. Between these two areas, strong early Laramide uplift of the east-central part of the range is indicated at Goslin Mountain, where the late Campanian Ericson Sandstone was overturned and faulted before the Fort Union Formation (Paleocene) was deposited. If the Lewis Shale was ever deposited there, it was removed by pre-Fort Union erosion. Obvious chips of Mowry Shale and probable gastroliths from the Morrison Formation or the Cloverly are preserved in the Fort Union conglomerates at Goslin Mountain. Their presence indicates 2,400-3,000 m of erosion off the Uinta anticline by Paleocene time (Hansen and Bonilla, 1954, p. 11; Hansen, 1965, p. 170). No really coarse debris was shed from the Eastern Uintas at that time, but little rock hard enough to yield coarse debris had yet been exposed.

By Wasatch time (early Eocene) the eastern part of the range was eroded to its Precambrian core, as cobbles from the Uinta Mountain Group accumulated in the main body of the Wasatch Formation north of Clay Basin (Hansen and Bonilla, 1954, p. 11; Wiegman, 1964, p. 41) and in the Tipton Tongue of the Green River Formation southwest of Vermillion Creek (Sears and Bradley, 1925, p. 97; Ritzma, 1955, p. 38). Just north of Manila, near the Henrys Fork fault (fig. 25), the Wasatch contains very bouldery conglomerate derived from most of the resistant formations in the nearby mountains down to and including Mississippian rocks. The clasts appear in the Wasatch section in the reverse order of their original stratigraphic positions. The coarseness of these deposits suggests a nearby source higher than the present Uintas. One limestone boulder $3.3 \mathrm{~m}$ across must have been traveled at least $13 \mathrm{~km}$. Major uplift of the Uintas during Tipton time may have coincided with movement on the Henrys Fork fault (Anderman, 1955, p. 131), with renewed movements on the Uinta fault north of Goslin Mountain, where the Fort Union is faulted against the Uinta Mountain Group (Hansen, 1965, p. 170), and with the flood of coarse debris into the Tipton near Vermillion Creek (Schultz, 1920, p. 31; Sears and Bradley, 1925; Ritzma, 1955, p. 39). The Laramide orogeny apparently ended in the Eastern Uinta Mountains after the youngest Eocene rocks had been deposited, including the bulk of the Duchesne River Formation, whose upper member, the Starr Flat Member of Andersen and Picard (1972), is conglomeratic near the mountains. The Starr Flat Member probably is Oligocene (Andersen and Picard, 1972, p. 16; Emry, 1981). The range then lapsed into a long period of quiescence, during which the Gilbert Peak erosion surface began to take form. On the south flank of the Uinta Mountains, however, the Starr Flat Member(?) rests unconformably on a truncation surface that might be the Gilbert Peak erosion surface. If so, the surface may have begun to form in late Eocene or early Oligocene time. Basinward from the mountains the Starr Flat Member apparently intertongues with the subjacent Lapoint Member of the Duchesne River Formation (of Andersen and Picard, 1972, p. 15-16). Perhaps the Starr Flat and the Bishop are isochronous.

Compressive Laramide severing of the Uinta anticline from its root has been suggested by several workers, as noted by Hamilton (1981, p. 90). Stokes (1976) and Sears and others (1982, fig. 5) have postulated a Precambrian aulacogen, which may subsequently have influenced Laramide and later Tertiary structural trends. Regional northward tilting in a similar mode in Late Proterozoic (?) time (Hansen, 1977a) and stratigraphic thickening along the Uinta Mountains through parts of Phanerozoic time (Hansen, 1965) seem to support the aulacogen concept or, at least, the probability of an east-trending structural trough bounded by faults. Bryant (1985) has summarized evidence of an easttrending continental margin along the site of the Uinta Mountains in Archean time. This margin might have affected tectonic events through much of subsequent geologic time. Bryant's concept does not contradict the evidence of a later east-west trough along the Uinta trend.

Laramide propagation of fracturing beneath the flanks of the range (fig. 26, inset) might best be visualized as underthrusting due to crowding of the thick prism of Uinta sediments between the Colorado Plateau 
TABLE 2.-Summary of Tertiary and Quaternary tectonic, geomorphic, and sedimentologic events in the Eastern Uinta Mountains

[See figure 25 for locations of tectonic features]

\begin{tabular}{|c|c|c|}
\hline 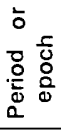 & Tectonic events & Geomorphic and sedimentologic events \\
\hline 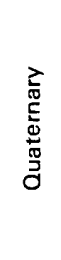 & $\begin{array}{l}\text { Normal faulting along Diamond Gulch and along Pot } \\
\text { Creek. } \\
\text { Latest movement along Sparks fault, down to the } \\
\text { northeast. } \\
\text { Rise of Continental Divide at Tipton. } \\
\text { Eruption of Leucite Hills lavas } 1.1 \mathrm{m.y} \text {. ago (McDowell, } \\
1971 \text { ). }\end{array}$ & $\begin{array}{l}\text { Terracing of stream valleys and continued drainage adjustments; superposition and entrench- } \\
\text { ment of Bull Canyon. } \\
\text { Diversion of Sheep Creek into present subsequent course. } \\
\text { Superposition of Swallow Canyon in Browns Park. } \\
\text { Beheading of Irish Canyon and diversion of Vermillion Creek. } \\
\text { Diversion of Upper Green River at Green River, Wyo., into present course; interior drainage at } \\
\text { Great Divide Basin; rejuvenation of Green River system. } \\
\text { Diversion of Spring Creek; abandonment of Dutch John Gap. } \\
\text { Continued reexcavation of Browns Park. }\end{array}$ \\
\hline  & $\begin{array}{l}\text { Postulated resurgence of Cross Mountain (Hunt, 1969, } \\
\text { p. } 89 \text { ) and Deerlodge monocline. } \\
\text { Continued northward and eastward tilting of Eastern Uinta } \\
\text { Mountains accompanied by faulting of Browns Park For- } \\
\text { mation along northwest margin of Browns Park and } \\
\text { structural enhancement of 8rowns Park-Lay syncline. }\end{array}$ & $\begin{array}{l}\text { Superposition of Yampa River at Cross Mountain and Juniper Mountain. } \\
\text { Integration of Yampa River drainage in Uinta Mountains; excavation of Yampa Canyon. } \\
\text { Reexcavation begins in Browns Park valley and Red Canyon. } \\
\text { Entrenchment of Green River begins in Lodore Canyon. }\end{array}$ \\
\hline 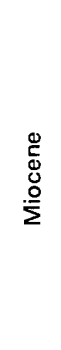 & $\begin{array}{l}\text { Deformation of Browns Park Formation and growth } \\
\text { faulting in Elk Springs-Maybell area (Dyni, 1980). } \\
\text { Large-scale tilting of Eastern Uinta Mountains; warping } \\
\text { and faulting of Gilbert Peak erosion surface; normal } \\
\text { faulting in Red Canyon-Browns Park area; subsidence } \\
\text { and faulting in Maybell-Lay area; renewed movements } \\
\text { on Island Park and Disaster faults in Dinosaur area (fig. } \\
\text { 30). } \\
\text { Gravitative reversal on Uinta fault. }\end{array}$ & $\begin{array}{l}\text { Overtopping of Browns Park valley with sediment (Browns Park Formation) at Gates of Lodore; } \\
\text { diversion of Green River southward across site of Lodore Canyon. } \\
\text { Deposition of Browns Park Formation } 25-9 \text { m.y. ago and possibly into Pliocene time along col- } \\
\text { lapsed axis of Uinta anticline; initiation of Browns Park-Lay syncline by deposition and com- } \\
\text { paction; ancestral Yampa River empties into Maybell-Lay basin. Filling of ancestral Red } \\
\text { Canyon. } \\
\text { Pre-Browns Park pedimentation northeast side Cold Spring Mountain. } \\
\text { Erosional breaching of Uinta anticline; west to east drainage begins along Red Canyon-Browns } \\
\text { Park alinement; southerly drainage begins off tilted Gilbert Peak erosion surface into Red Can- } \\
\text { yon and Browns Park (Spring, Goslin, Red, Willow, Beaver, and Vermillion Creeks); beheading } \\
\text { of Wolf Creek by Hells Canyon; initial drainage Pot Creek and Diamond Gulch; initial drainage } \\
\text { of Little Snake River. }\end{array}$ \\
\hline $\begin{array}{l}\stackrel{0}{\circ} \\
\stackrel{0}{0} \\
\stackrel{\circ}{0} \\
0\end{array}$ & $\begin{array}{l}\text { Crustal stability. } \\
\text { Regional uplift; continued differential rise of Uinta Moun- } \\
\text { tains; warping of Colorado Plateau (Hunt, 1969). } \\
\text { End of subsidence of Tertiary basins. }\end{array}$ & $\begin{array}{l}\text { West-flowing consequent drainage along site of Yampa Canyon. } \\
\text { Consequent drainage down slopes of Gilbert Peak erosion surface and across Bishop Con- } \\
\text { glomerate on both flanks of Uinta Mountains. } \\
\text { Deposition of Bishop Conglomerate (beginning about } 30 \text { m.y. ago); increasing aridity. } \\
\text { Pedimentation of Gilbert Peak erosion surface; first exposure of Red Creek Quartzite since } \\
\text { Precambrian time. Truncation of Rock Springs uplift by Gilbert Peak erosion surface. } \\
\text { Regional dissection; lowering of base levels in basins; climatic cooling and drying. } \\
\text { Eastward drainage of Green River Basin toward North Platte River. } \\
\text { Climate turns cooler and drier. } \\
\text { Continued deposition of Duchesne River Formation (Andersen and Picard, 1972; Emry, 1981). }\end{array}$ \\
\hline & $\begin{array}{l}\text { Continued rise of Uinta Mountains. } \\
\text { Rise of Axial Basin anticline; resurgence of Rock Springs } \\
\text { uplift and Douglas Creek arch (possibly Oligocene); } \\
\text { renewed compressive movement on Uinta fault. } \\
\end{array}$ & $\begin{array}{l}\text { Deposition of Bridger, Uinta, Washakie, and Duchesne River Formations. } \\
\text { Blockage of north-south drainage across Axial Basin by rise of Axial Basin anticline. } \\
\text { Extinction of Lake Uinta } 41-40 \mathrm{~m} . y \text {. ago (Mauger, 1977); opening of permanent drainage south } \\
\text { out of Uinta Basin (Hunt, } 1969 \text { ). } \\
\text { Extinction of Lake Gosiute } 45-44 \mathrm{~m} . y \text {. ago (Mauger, 1977). } \\
\text { Interconnection of Lake Gosiute and Lake Uinta about } 45 \mathrm{~m} \text {.y. ago. } \\
\text { Burial of Rock Springs uplift by Green River Formation (Roehler, 1965). } \\
\text { Burial and inundation of Douglas Creek arch, but thinning of Green River Formation and Wasatch } \\
\text { Formation across arch (Dyni, 1981, p. } 100 \text { ). } \\
\text { Expansion of Eocene Lakes Uinta and Gosiute, Green River Formation. } \\
\text { Continued alluviation, Wasatch Formation. } \\
\text { Uinta Mountains eroded to Precambrian core; development of Wild Mountain upland erosion } \\
\text { surface across Eastern Uinta Mountains. }\end{array}$ \\
\hline  & $\begin{array}{l}\text { Compressive movements along Uinta, Yampa, and Island } \\
\text { Park faults and others. }\end{array}$ & $\begin{array}{l}2,400-3,050 \mathrm{~m} \text { of dissection into crest of Uinta anticline. } \\
\text { Unconformable overlap by Fort Union Formation across Cretaceous rocks (Erickson, Rock } \\
\text { Springs, and Hilliard Formations) of Eastern Uinta Mountains; thinning of Fort Union over Rock } \\
\text { Springs uplift (Roehler, 1961); truncation of Cretaceous on Douglas Creek arch and Rock } \\
\text { Springs uplift. } \\
\text { Consequent drainage off Uinta anticline and beginning of subaerial erosion; alluviation begins } \\
\text { in newly formed basins; inception of Lake Uinta (Ryder and others, 1976). }\end{array}$ \\
\hline 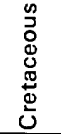 & $\begin{array}{l}\text { Initial rise of Uinta Mountains, Rock Springs uplift and } \\
\text { Douglas Creek arch and subsidence of adjacent basins } \\
\text { (Bradley, 1964; Gow, 1950; Hansen, 1965; Hunt, } \\
\text { 1956, 1969; Ritzma, 1965a; Roehler, 1961). }\end{array}$ & Withdrawal of Cretaceous Interior seaway. \\
\hline
\end{tabular}


to the south and the Wyoming Basin to the north. The Uinta fault has a pre-Laramide history, probably as a normal fault, and the Laramide arching of the Uinta anticline would have effectively reduced the dip of the fault to an attitude conducive to thrusting along the preexisting fracture (Hansen, 1984, p. 9). The asymmetry of the fold suggests that the range has translated northward relative to the Green River Basin. It verges northward, and the north limb is steeper than the south. Perhaps the Uinta Basin boundary fault is a back thrust on which the south limb has ridden passively over an underthrust Uinta Basin margin.

The long period of crustal stability needed to form the Gilbert Peak erosion surface and to deposit the overlying Bishop Conglomerate across thousands of square kilometers-perhaps as much as $26,000 \mathrm{~km}^{2}-$ ended with renewed deformation in an extensional mode that brought about notable changes in the pattern and regimen of drainage. This deformation is well documented, but in some places it is masked by movements that followed the deposition of the Browns Park Formation. These movements may, in fact, have been part of a continuum of alternate activity and quiet, but the greater part of the deformation seems to have preceded the deposition of the Browns Park Formation.

After the Bishop was deposited the whole eastern part of the range began to founder, partly by regional warping and partly by localized displacements along faults. Figure 26 explains the observed deformation as a consequence of north-to-south rotation of the range. Rotation is expressed in tilted erosion surfaces. I suggest that the Eastern Uinta Mountains have rotated over a root severed by Laramide or earlier faultingthat a faulted, semirigid upper crust has rotated over a ductile lower crust at a depth of perhaps $20 \mathrm{~km}$ in response to regional north-south extension. Such rotation requires a curved fault surface and a mass imbalance. Imbalance is indicated by a relative positive Bouguer gravity anomaly over the north flank of the range (Behrendt and Thiel, 1963) and by the fact that the axis and heights of the range are closer to the north flank than the south. Rotation has not taken place under the western part of the range, where flanking subthrusts appear to be planar (Clement, 1977; Gries, 1981). The rotation and subsidence as thus visualized would be taken up partly by fault slippage and partly by monoclinal flexing under the south flank over the concealed Uinta Basin boundary fault.

Middle to late Tertiary extensional deformation is common in other ranges of the Rocky Mountain foreland. (See Ingersoll, 1982, for example.) Among other things, it is responsible for the subsidence of the south part of the Wind River Range, of the south part of the Owl Creek Mountains, and of the Granite Moun- tains, all in central Wyoming (Keefer, 1970; Love, 1960, $1970,1971)$. In general, post-Laramide extensional deformation was more complicated along the north flank of the Eastern Uinta Mountains than along the south (not surprisingly, as Laramide uplift and faulting were greater on the north flank), but the overall effect was a lowering of the crest of the range, relative to both flanks, and inward tilting of both flanks. Maximum subsidence was along the zone of faults that trends eastward to southeastward from Bear Mountain to Browns Park, thence along the northeast border of Browns Park to and beyond the east end of the range (fig. 27).

\section{NORTH FLANK}

Most of the post-Bishop deformation on the north flank was concentrated between the above-noted zone of faults and the Uinta fault a few miles north. Some faults that had Laramide or earlier movements were reactivated. A reversal of movement on the south-dipping Uinta fault has been recognized since the time of Powell. Its large compressional Laramide displacement-up on the south, with a probable component of left-lateral strike slip (Hansen and Bonilla, 1954, p. 15; Hansen, 1965, p. 158)-was countered by a much smaller, post-Bishop gravitative reversal. This movement, down to the south, amounted to about $520 \mathrm{~m}$ between Cold Spring Mountain and Diamond Peak (Bradley, 1936, fig. 18) and about $790 \mathrm{~m}$ at Goslin Mountain. It was accompanied by marked warping between the Uinta zone and the Bear Mountain-Browns Park zone. Bear Mountain has been lowered about $975 \mathrm{~m}$ since Bishop time by gravitative movement on the Uinta fault. (See p. 57.) North of the Uinta fault, the Miller Mountain area (Bradley, 1936, p. 185) and the lookout Mountain area were tilted northward, increasing the northward gradient of the Gilbert Peak erosion surface.

South of the Uinta fault, O-Wi-Yu-Kuts Mountain was bowed upward relative to adjacent Cold Spring and Bender Mountains-its crestline now forms a broad east-west arch-but the whole area of these mountains dropped with respect to the north side of the Uinta fault. As one crustal block, the area of Goslin, Bender, O-Wi-Yu-Kuts, and Cold Spring Mountains also was tilted southward, flattening and reversing the slope of the Gilbert Peak erosion surface and thereby redirecting the runoff into the newly formed drainage line of Browns Park.

The southerly component of tilt gradually increased westward from Cold Spring Mountain to a maximum at Goslin Mountain, where the present southward slope of the Gilbert Peak surface is about $83 \mathrm{~m} / \mathrm{km}$. Southerly tilt extended west from Goslin Mountain at a diminishing rate at least as far as Bear Mountain and probably 


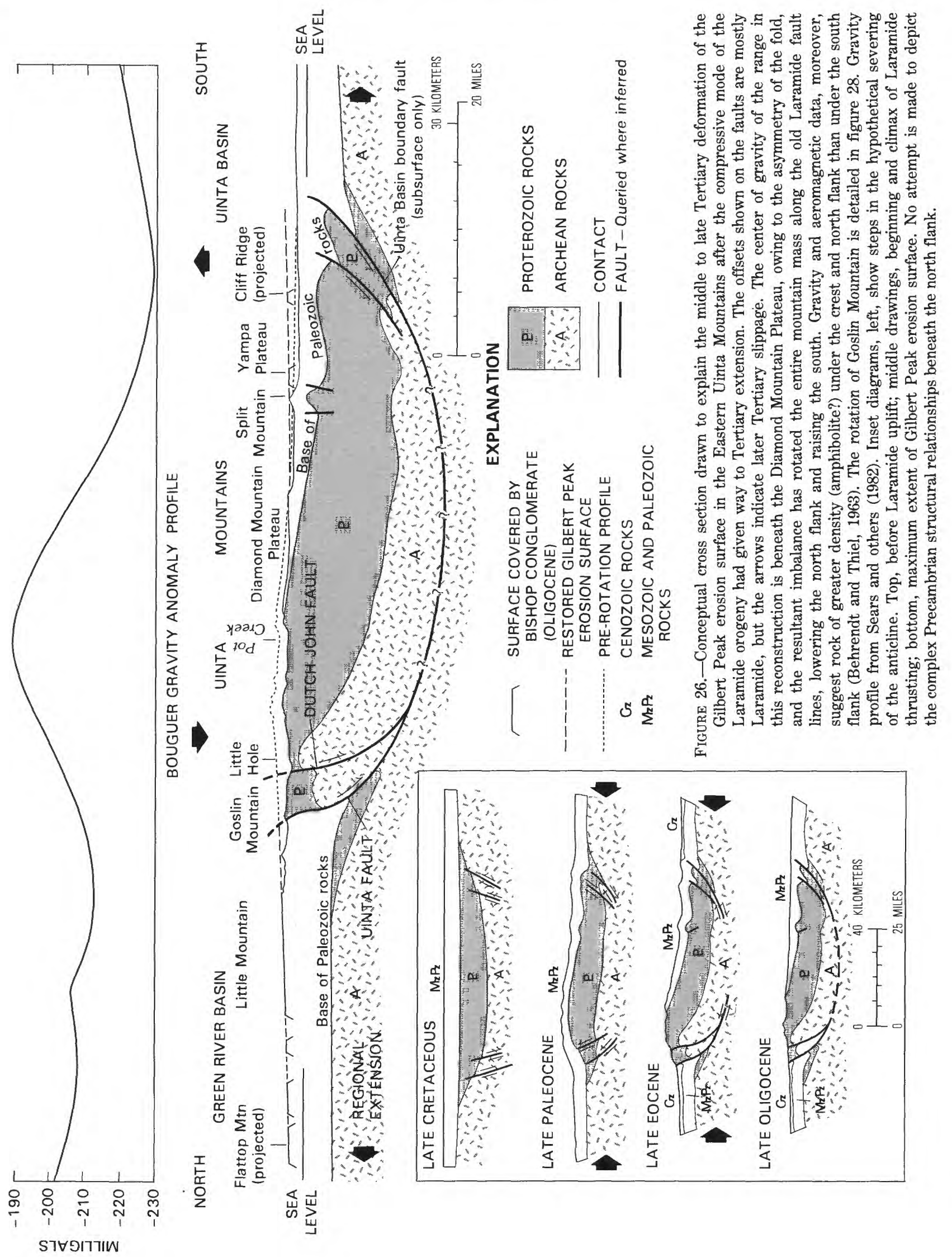



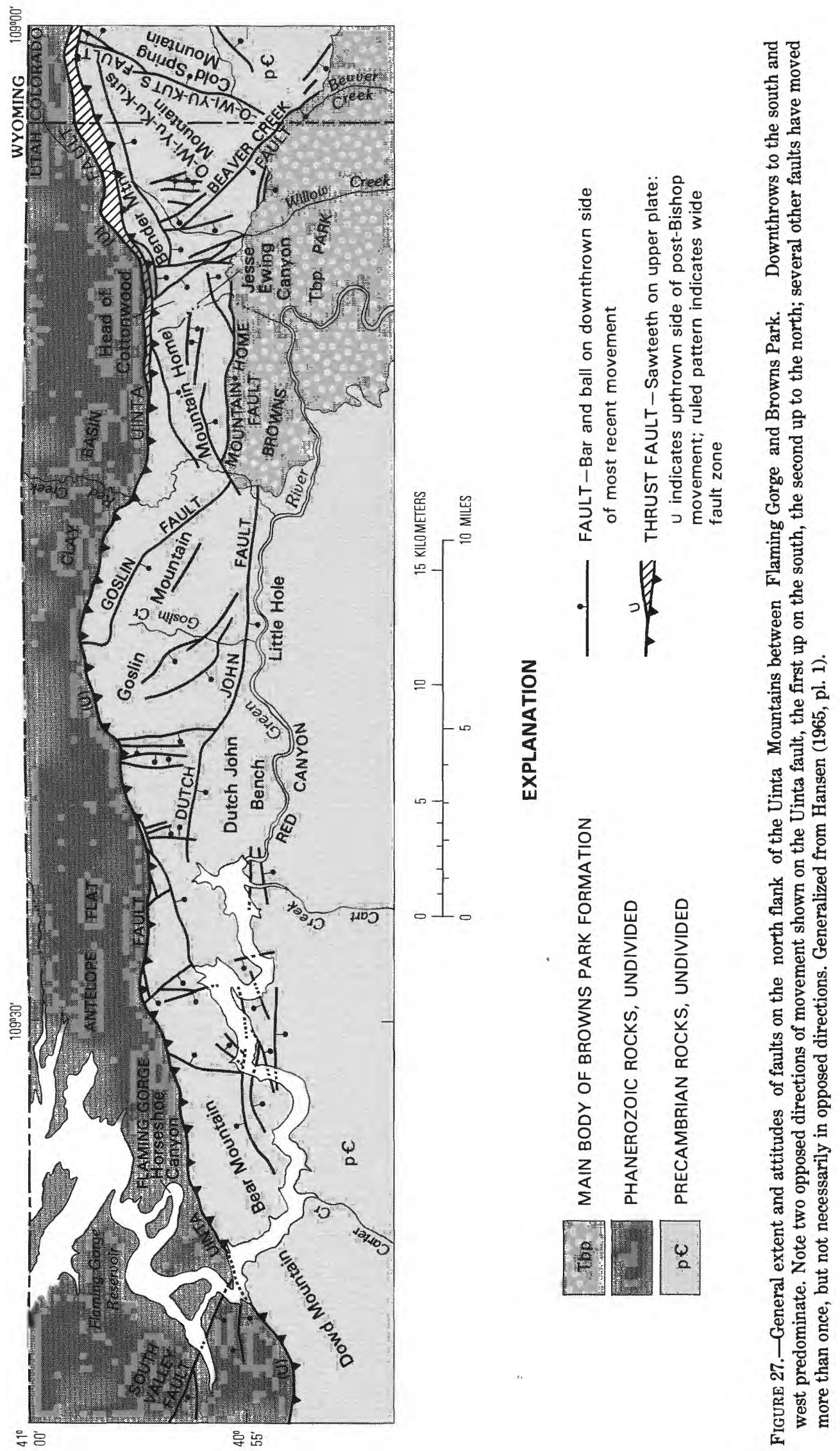
to Phil Pico, west of Manila. The southerly slope of this mountain's flattish summit is most distinct as seen from an aircraft. Inasmuch as the initial slope of the Gilbert Peak erosion surface on Goslin Mountain was northward-probably about $38 \mathrm{~m} / \mathrm{km}$, judging from Bradley's reconstruction of the undisturbed Hickey Mountain profile farther west (1936, table, p. 174)-the total amount of southward tilting on Goslin Mountain probably was about $120 \mathrm{~m} / \mathrm{km}$.

North to south, Goslin Mountain is about $5.6 \mathrm{~km}$ across. If tilted southward at $120 \mathrm{~m} / \mathrm{km}$, its south end at Little Hole has been lowered about $700 \mathrm{~m}$ relative to its north end at the Uinta fault since Gilbert Peak time. Using those figures and relating the tilting of Goslin Mountain to the area immediately to the south, and to O-Wi-Yu-Kuts Flats and Pine Mountain to the east, I estimated (Hansen, 1965) that the total collapse of the crestline of the Uinta Mountains south of Goslin Mountain was about $1,370 \mathrm{~m}$. If that figure is added to the present mean altitude of the crestline south of Goslin Mountain-now about 2,740 m-the restored altitude before collapse is $4,115 \mathrm{~m}$. This figure almost exactly equals the maximum present height of the western part of the range that was unaffected by postGilbert Peak subsidence (Hansen, 1965, p. 172).

Comparable but more refined results can be obtained graphically by projecting the gradient of the Gilbert Peak erosion surface southward from Little Mountain in Wyoming across the Uinta fault to Goslin Mountain in Utah and assuming that the surface steepened from a measured $24 \mathrm{~m} / \mathrm{km}$ at Little Mountain to an assumed $38 \mathrm{~m} / \mathrm{km}$ at Goslin Mountain, as explained in the preceding paragraphs. This reconstruction (fig. 28) assumes that the Uinta fault is a downward-steepening fracture that dips about $60^{\circ}$ south-a dip indicated by the attitude of sheeting in the fault gouge just east of Goslin Mountain at Red Creek and by the attitude of large tabular slices of resistant rock caught in the fault zone. The dip may be a bit lower at Cold Spring Mountain, perhaps about $45^{\circ}$ (Hansen, 1984, p. 17). Downward steepening, or upward flattening, is suggested by overturning in the foot wall far back from the fault trace. With that geometry, any renewed down-to-the-south movement of the Uinta fault would rotate the Gilbert Peak erosion surface southward. The observed rotation geometry of the Gilbert Peak erosion surface, in fact, demands a curved fault surface. The present southward slope of Goslin Mountain would result if the rotation were about $5^{\circ}$ of arc, the radius of curvature were about $12 \mathrm{~km}$, and the downthrow were about $790 \mathrm{~m}$. This downthrow is appreciably more than what Bradley (1936) calculated $(520 \mathrm{~m})$ for the subsidence of Cold Spring Mountain $32 \mathrm{~km}$ or so to the east, but the southward rotation of Cold Spring Mountain is much less than that of Goslin Mountain, and the downfaulting, accordingly, should be less also. Cold Spring Mountain's altitude-about $150 \mathrm{~m}$ higher than Goslin Mountain-also indicates less displacement. Furthermore, the Gilbert Peak erosion surface has a strong westerly tilt component between Cold Spring Mountain and Goslin Mountain (Hansen, 1965, p. 163, fig. 63), which would increase the displacement at Goslin Mountain also. Projecting the Gilbert Peak erosion surface south to Little Hole suggests that the south end of Goslin Mountain has been lowered about $1,280 \mathrm{~m}$.

South of Little Hole, across the Dutch John fault. zone at the foot of Goslin Mountain, the crest of the Uinta Mountains has been lowered about $300 \mathrm{~m}$ more, relative to the south end of Goslin Mountain, judging from the profile, figure 28 . Added to the $1,280 \mathrm{~m}$ of



FIGURE 28.-Cross section through Goslin Mountain area showing post-Gilbert Peak gravitative movement on the Uinta fault, rotational displacement of the Gilbert Peak erosion surface, and extent of displacement (in meters). 
deduced subsidence at the south end of Goslin Mountain, this figure gives a total collapse of the crestline of about $1,590 \mathrm{~m}$. This figure can be duplicated by simply projecting the restored Gilbert Peak erosion surface south from Goslin Mountain and measuring its height above remnants preserved south of Little Hole.

Tilting and displacement similar to that described in the preceding paragraphs can be obtained if a dip lower than that postulated here is assumed for the Uinta fault, so long as the fault surface remains convex upward. Some geologists have suggested dips as low as $10^{\circ}$. However, the amount of extension required to achieve the observed tilting increases rapidly as the assumed dip angle is reduced.

\section{SOUTH FLANK}

A northerly tilt along the south flank of the Uinta Mountains, as expressed in the attitude of the Bishop Conglomerate, is visible from many vantage points on or above the Bishop outcrop all the way from Diamond Mountain northeast of Vernal to the extreme east end of the range. This tilting reversed the drainage of several small streams along the crest of the range, redirecting them from their old south-flowing courses into the newly formed Browns Park valley. Even though the slope to the north is low, mostly only 1 or 2 degrees, the pattern of barbed drainages is obvious and remarkable. Inasmuch as the original slope of the pediment and the depositional slope of the Bishop were southward, the present slope is a minimal measure of the actual amount of tilt.

Tilt is well documented in the Stuntz Reservoir quadrangle, where the Gilbert Peak erosion surface is well preserved and is little deformed except for tilting (fig. 29). There it is partly mantled with patchy Bishop Con- glomerate and hence is readily depicted in profile (Hansen and Rowley, 1980b, map and section $C-C^{\prime}$ ). In that area the northward slope of the surface is about 16-17 $\mathrm{m} / \mathrm{km}$, some parts being a bit steeper than others. The original slope of the erosion surface in the opposite direction, however, may have been as much as $13 \mathrm{~m} / \mathrm{km}$, perhaps appreciably more, judging again from the undeformed Hickey Mountain profile on the north slope of the range. An original slope of $13 \mathrm{~m} / \mathrm{km}$ toward the south added to the present northward slope would yield a minimal northerly tilt component of $28 \mathrm{~m} / \mathrm{km}$ since the Bishop Conglomerate was deposited. That order of tilt, if uniform over a distance of $56 \mathrm{~km}$-the distance from the south boundary of the Stuntz Reservoir quadrangle to the crest of the Uinta anticline-would amount to differential subsidence of about $1,600 \mathrm{~m}$ at the crestline. Without a known fixed datum the absolute subsidence cannot be determined, but this figure agrees closely with the estimated subsidence farther west at Goslin Mountain.

\section{NONUNIFORM TILTING ON THE SOUTH FLANK}

Farther west on the south flank of the range, nonuniform tilting has been noted northwest of Vernal, where remnants of the Bishop Conglomerate straddle the South Flank fault zone (Kinney, 1955, p. 127). There the Gilbert Peak erosion surface has been warped into a shallow syncline whose axis is parallel to the fault zone and is about 3 miles south of it. The limbs of the syncline slope $38-57 \mathrm{~m} / \mathrm{km}$ (D. M. Kinney, written commun., 1959). A synclinal structure there could result from a north-side-down movement on the subsurface Uinta Basin boundary fault of Ritzma (1969). Kinney also noted that the Gilbert Peak surface gradually decreases in altitude eastward from the Uinta River toward Diamond Mountain.

NORTH

SOUTH

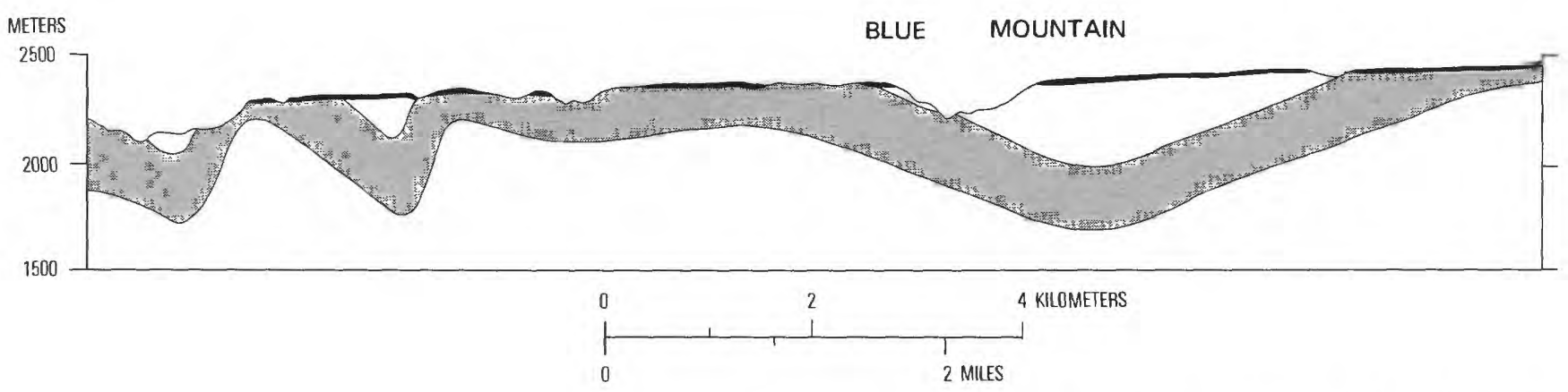

FIGURE 29.-Geologic section across Blue Mountain near Colorado-Utah state line showing northerly tilt of Gilbert Peak erosion surface, partly mantled by Bishop Conglomerate (heavy line). Surface here truncates folded Paleozoic rocks and originally sloped south. Weber Sandstone (shaded) is outlined to show truncation. Vertical scale is twice horizontal. From Hansen (1984), based on Hansen and Rowley (1980b, section $\mathrm{C}-\mathrm{C}^{\prime}$ ). 
In the Diamond Mountain area, generalized structure contouring on the base of the Bishop Conglomerate indicates nonuniform warping centered on Island Park (fig. 30). This warping probably is a result of postBishop activity along the Island Park fault zone at the downwarped northwest border of the Split MountainRuple Ridge-Harpers Corner crustal block-what Powell (1876, p. 177) called the Island Park sag. The
Diamond Mountain side has been lowered $60-120 \mathrm{~m}$ relative to Harpers Corner, judging from the structure contours. This displacement is plainly discernible on the ground from distant vantage points. Quaternary faulting also cuts the Bishop on Diamond Mountain along a west-northwest fault zone just south of Diamond Gulch. Several kilometers northeast of Diamond Gulch along Pot Creek, a synclinal closure straddles a zone

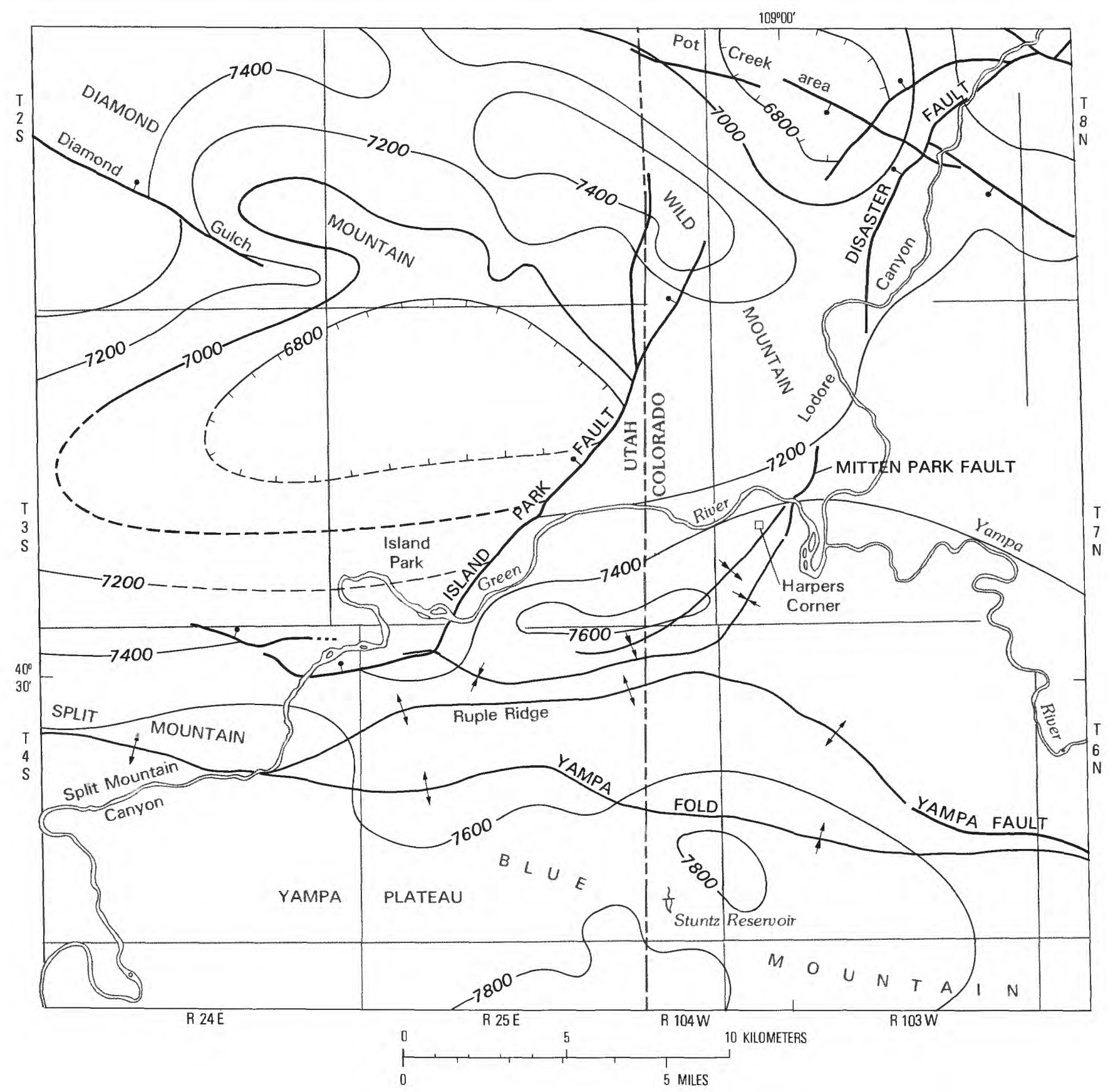

Figure 30.-Structure contours drawn on the Gilbert Peak erosion surface (base of Bishop Conglomerate) in the area of Diamond Mountain, Island Park, and Blue Mountain, showing post-Bishop faulting and warping. Contour interval is 200 feet (about $61 \mathrm{~m}$ ). Dashed contours project above eroded ground level. Hachures indicate negative structural closure. Bar-and-ball symbol shows downthrown side of fault. 
of very old faults that have had Quaternary movement in the Crouse Reservoir area (Hansen and others, 1981). One of these faults in Lodore Canyon contains a dike of Late Cambrian or Early Ordovician age (Hansen and others, 1982, 1983). These faults also trend west-northwest.

\section{WEST-TO-EAST TILTING ON THE SOUTH FLANK}

Although west-to-east tilt is clearly visible on the south flank of the Eastern Uintas, it is difficult to quantify because the original surface sloped away from the crestline and because the surface has also been modified by the northerly tilt component. As a rough measure of the easterly tilt north of Vernal, however, the present surface descends about $900 \mathrm{~m}$ west to east, from about 3,050 $\mathrm{m}$ just west of the Uinta River to about $2,135 \mathrm{~m}$ at Diamond Gulch-a rate of about $12 \mathrm{~m} / \mathrm{km}$. This tilt is shown graphically by figure 31 .

\section{CLIFF RIDGE AREA}

In the Dinosaur area, easterly tilt is also evident from Cliff Ridge, one of the most southerly parts of the Gilbert Peak erosion surface and the highest point on that surface south of the line of the Yampa River (summit elevation about 2,524 m). From Cliff Ridge the Gilbert Peak surface and the Bishop Conglomerate slope northeast and east toward the Stuntz Reservoir area and Mud Springs Draw (a tributary of Hells Canyon). Stuntz Ridge, which is a topographic continuation of Cliff Ridge, was a monadnock that stood above the Gilbert Peak surface and received no gravel. Its smoothly graded crestline suggests that it is a remnant of the Wild Mountain upland surface. The gravel that spread out into Mud Springs Draw must have come from the north via Cliff Ridge, because it contains abundant red quartzite clasts from the core of the range to the north, but it detoured around the west side of Stuntz Ridge. Bishop Conglomerate preserved on the south side of Stuntz Ridge caps a narrow berm that slopes east toward Mud Springs Draw (fig. 32).

The northerly component of tilt from Cliff Ridge is manifest in the slope to the Yampa Plateau, whose conglomerate-capped summit is about $2,350 \mathrm{~m}$ in altitude, and to Split Mountain, a bit farther northwest at 2,315 $\mathrm{m}$. Split Mountain's summit is a point on the Gilbert Peak erosion surface, but it lacks a gravel cap. Thirteen kilometers due north of Split Mountain, the rim of Diamond Mountain also reaches slightly above $2,315 \mathrm{~m}$, but the conglomerate is at least $90 \mathrm{~m}$ thick there, so the elevation of the underlying Gilbert Peak surface is, accordingly, about $2,225 \mathrm{~m}$.

\section{MUD SPRINGS DRAW AND WOLF CREEK}

East along Mud Springs Draw and Wolf Creek the general easterly tilt component is expressed in a rather

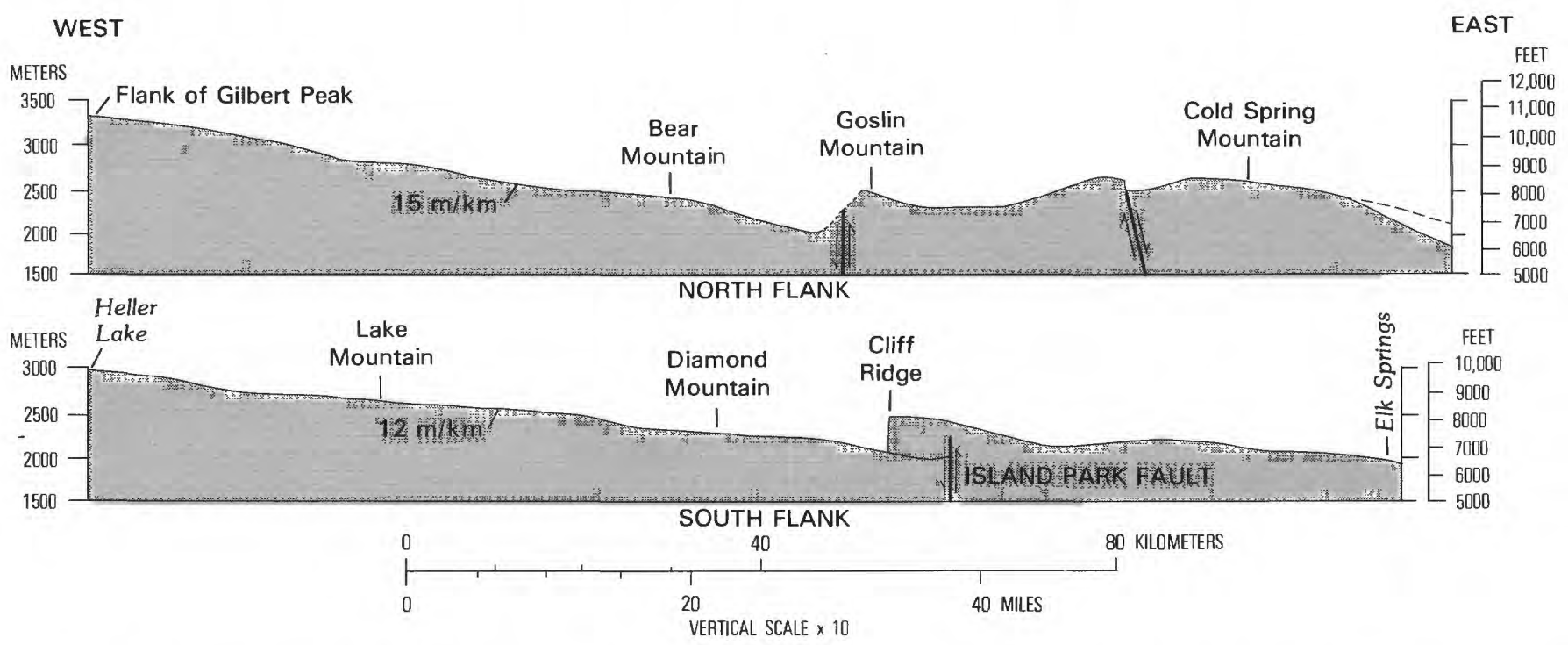

Figure 31.-Profiles along the flanks of the Uinta Mountains, showing the west-to-east decline in the altitude of the Gilbert Peak erosion surface. Vertical scale is 10 times the horizontal scale. Profile segment from Heller Lake to Island Park fault is about $24 \mathrm{~km}$ farther north than the segment from Cliff Ridge to Elk Springs. Part of the altitude difference between Cliff Ridge and Diamond Mountain is due to offset fault blocks, but part is due also to a northerly component of tilt. Points on the profiles are taken from maps by Kinney (1955, plate 1), Rowley and others (1979), Hansen and others (1983), and the Vernal $1^{\circ} \times 2^{\circ}$ topographic sheet $(1: 250,000)$. 


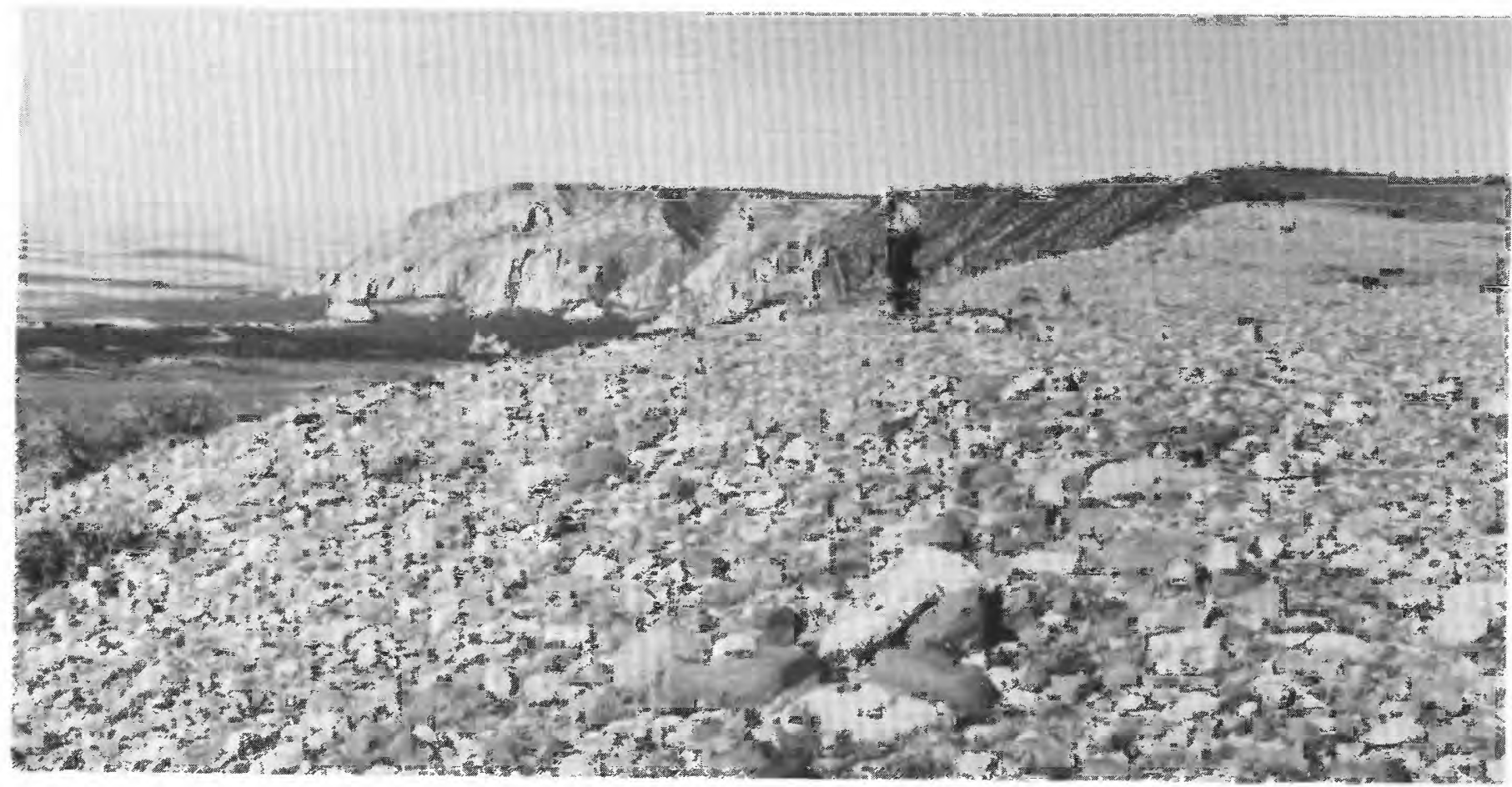

FiguRe 32.-A berm on the south flank of Stuntz Ridge, upper right, capped by Bishop Conglomerate, in Moffat County, Colo., just east of the Colorado-Utah State line. Dark, rounded cobbles are from the Uinta Mountain Group and light ones are mostly from Paleozoic limestones. Cliff Ridge, in the distance to the west, is topped by a remnant of the Gilbert Peak erosion surface and by patchy Bishop Conglomerate. The berm rises west toward Cliff Ridge.

narrow belt of Bishop Conglomerate about $32 \mathrm{~km}$ long. In that distance the altitude of the Bishop descends about $300 \mathrm{~m}$, a rate of $10 \mathrm{~m} / \mathrm{km}$. Some of this slope may be initial dip and may represent the depositional gradient of the Bishop Conglomerate before tilting, inasmuch as the proportion and coarseness of clasts derived from the Uinta Mountain Group diminish eastward. Figure 33 shows that a shallow synclinal warp at the base of the Bishop south of Hells Canyon probably is a response to post-Bishop movement along the Mud Springs monocline. This downwarp is centered along the length of Blue Mountain, and because the Bishop Conglomerate coincides with the downwarp, the monocline appears to have helped localize the deposition of Bishop in that area. The downwarp thus had negative relief before the gravel was deposited, as well as after.

Fingers of gravel reached north from Wolf Creek up narrow tributaries that drained the heights of Round Top Mountain, Marthas Peak, Tanks Peak, and Bear Valley Ridge. Many patches of this gravel still remain, now loosely cemented into conglomerate or coarse sandstone, but the tilt component cannot be measured, owing to the scatter of the remnants and uncertainty as to their original gradients. Northerly tilt is indicated, however, by a reversal of streams that now drain north to the Yampa River but formerly flowed south into Wolf Creek. Johnson Draw (figs. 33 and 39) is a good example (Hansen and Carrara, 1980). Turner Creek and Mud Springs Draw are others-captured by north-draining Hells Canyon (Hansen and Rowley, 1980a).

\section{SOUTHEAST END OF THE RANGE}

At the southeast end of the range, the subsidence of the Uinta arch and its southeastward extension, the Axial Basin anticline (west part) lowered the Bishop Conglomerate below present drainage. Much of the deformation there is younger than the Browns Park Formation, but some of it is older, and it produced a sag into which the Browns Park Formation was deposited on or partly on the Bishop. In nearly continuous outcrop the Bishop extends from Bear Valley east to Elk Springs, declining in altitude from $2,440 \mathrm{~m}$ at the head of Bear Valley to $1,950 \mathrm{~m}$ at Elk Springs, where it passes beneath the white sands of the Browns Park Formation. East of Cross Mountain, where the Bishop is deeply buried by the Browns Park Formation, its altitude is less than 1,460 m (Dyni, 1980).

At Elk Springs, what I identify as Bishop Conglomerate is well exposed at the base of the Browns Park Formation in a large gravel pit. It contains the usual 


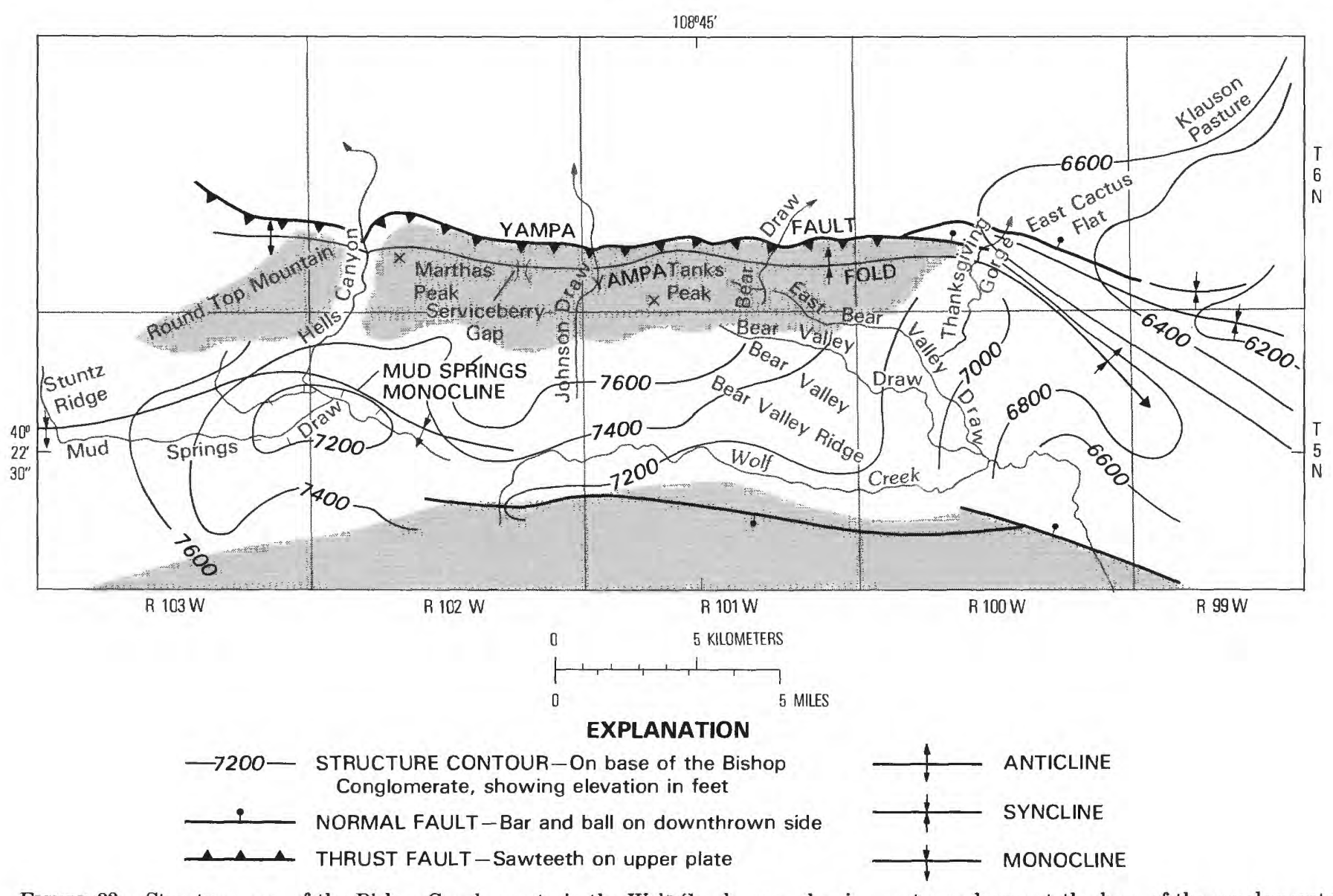

FIGURE 33. - Structure map of the Bishop Conglomerate in the Wolf Creek area, showing contours drawn at the base of the conglomerate; contour interval is 200 feet $(61 \mathrm{~m})$. Contouring indicates that post-Bishop warping resulted from renewed movements along preexisting structural features.

assemblage of Uinta Mountains rock types-red quartzite, gray limestone, and gray chert-in cobbles $10-15$ $\mathrm{cm}$ across and occasional boulders as large as $75 \mathrm{~cm}$ across (Dyni, 1980). The bedding attitude changes from a very low northeast dip-almost flat-to about $20^{\circ}$ to $25^{\circ}$ north in response to post-Browns Park deformation. Dyni (1980) has suggested that the Bishop (which he called the lower conglomerate unit of the Browns Park Formation) may have been deformed before or during deposition of the upper sandstone unit (of the Browns Park Formation). Dyni's suggestion corroborates my view about the disparate ages of the two formations.

East from Elk Springs the conglomerate continues along strike as a narrow line of outcrop at the base of the Browns Park Formation along Elk Springs Ridge, dipping about $25^{\circ}$ north and finally disappearing under Browns Park overlap east of Cedar Springs Draw. A deep downwarp between Elk Springs Ridge and Cross Mountain, broadening east toward Maybell, contains as much as $520 \mathrm{~m}$ of Browns Park rocks (Dyni, 1980). According to Dyni this trough may have formed over growth faults that were active during Browns Park deposition.

Due north from Elk Springs, the conglomerate is offset by several small faults, but it slopes gently north toward Lily Park at the confluence of the Little Snake and Yampa Rivers, forming the cap rock on the high mesas there (such as Twelvemile Mesa) $300 \mathrm{~m}$ above river level (Dyni, 1968). Eastward on Twelvemile Mesa it passes beneath the Browns Park Formation near Cross Mountain, but to the north, correlative deposits on Klauson Pasture stand about $200 \mathrm{~m}$ above the Browns Park Formation in the canyon of the Little Snake River. (See p. 32.) Though it is a loosely cemented, bouldery gravel and is nearly bare of the white sandstone cover west and north of Elk Springs, geologists back to the time of A. R. Schultz have included it in the Browns Park Formation. According to Dyni (oral commun., 1981), it is discontinuous beneath the Browns Park Formation and, hence, is hardly mappable. I suspect that it was partly removed by preBrowns Park erosion. 


\section{NORTHEAST END OF THE RANGE}

At the northeast end of the Uinta Mountains, between Vermillion Creek and Sand Wash, the whole flank of the Uinta anticline has been obscured by downwarping, faulting, erosion, and sedimentary overlap by the Browns Park Formation. Just west of Dry Mountain, the Browns Park Formation is as much as $600 \mathrm{~m}$ thick (Ritzma, 1965b, p. 131). A zone of mostly normal faults trends southeast from the Vermillion Creek area to and beyond the Little Snake River near Sunbeam. Most of these faults are downthrown toward the south. This zone is a structural continuation of the faulting along the northeast side of Browns Park, and it also merges with the Uinta-Sparks zone north of Cold Spring Mountain. It is partly overlapped by an unconformity within the Browns Park Formation (Ritzma, 1965 b, p. 131), which suggests intra-Browns Park deformation. Sears (1924a, p. 296) noted a similar local unconformity northwest of the mouth of Vermillion Creek. I interpret the faulting as a gravitative response to post-Laramide extension of the northeast flank of the range.

The Browns Park Formation itself, as well as the underlying Bishop—or basal Browns Park of earlier reports-is sharply tilted along the northern margin of its outcrop belt between Vermillion Creek and the Little Snake River. Dips commonly reach $20^{\circ}$ south and, locally, are as much as $40^{\circ}$ to $65^{\circ}$ south (McKay, 1974). The subjacent Eocene rocks, chiefly the Bridger Formation, dip northward beneath a marked unconformity into the Sand Wash Basin. This unconformity is presumably the Gilbert Peak erosion surface. The Bishop there is discontinuous. In part it has been deleted by faulting, and its locally steep dip is surely caused by drag, but in part the Bishop either was not deposited or was removed by pre-Browns Park erosion. Abrupt changes in thickness and the absence of Bishop in some sections point toward pre-Browns Park erosion rather than nondeposition. For example, between the Little Snake River and Simsberry Draw, a distance of only about $2.4 \mathrm{~km}$, the thickness diminishes abruptly from about $24 \mathrm{~m}$ (Izett and others, 1970) to less than $1 \mathrm{~m}$ (McKay, 1974), and the provenance changes from the Uinta Mountains to the Park Range. A few miles to the east, north of Sunbeam, S. J. Luft and I found the Browns Park Formation resting directly on the Wasatch, with no intervening conglomerate at all.

The main body of the Browns Park Formation through most of its exposure has the structure of a shallow syncline turned up sharply along its north and northeast margin by warping and discontinuous faulting. Mapping its western part, I called it the Browns
Park syncline (Hansen, 1965, pl. 1); McKay and Bergin (1974), mapping its eastern part, called it the Lay syncline, but it is a continuous structure and its axis is one and the same. Its axis trends east-southeast through most of its length, from the head of Browns Park to Sunbeam, then veers gradually eastward (Rowley and others, 1979). S. J. Luft (written commun., 1983) has traced it nearly to Craig. Luft has also traced a secondary axis southeast from Sunbeam toward Axial Basin.

This syncline coincides with the old erosional valley of Browns Park along the breached crest of the Uinta anticline and its extension, the Axial Basin anticline (Sears, 1924a, fig. 1; Hancock, 1925, pl. 19). I visualize the valley as developing along the depressed sag in the Gilbert Peak erosion surface. At Axial Basin the Browns Park Formation fills the valley floor below cliffs and highlands eroded from the Mesaverde Group on both flanks; hence the topographic configuration of Axial Basin at the time of Browns Park deposition was not greatly different from what it is now.

Mapping in Moffat County, Sears (1924a, p. 288) attributed the form of the syncline primarily to deformation, but he recognized the effects of initial dip into the old trough. Mapping farther west, I attributed the structure to a combination of (1) initial dip on the sloping floor of the old valley, (2) valleyward thinning of coarse-grained beds, and (3) differential compaction of fine-grained sediments, the total compaction being greatest in the thickest part of the deposit over the deepest part of the buried valley (Hansen, 1965, p. 154). Steep dips along the north and northeast margins of the old valley, however, are due to drag and flexing along and near faults. Along the Mountain Home fault at Jesse Ewing Canyon (figs. 27 and 40) near the head of Browns Park, for example, the dip approaches vertical (Hansen, 1965, pl. 1 and fig. 59). Less steep inclination along the south margin of the old fill along Elk Springs Ridge east of Elk Springs may be due to resurgence of the Elk Springs anticline, whose axis is just south of the outcrop (Dyni, 1968). There, beds that originally sloped southward from the Uinta Mountains now slope north.

At the confluence of the Little Snake and Yampa Rivers, the short, south-trending Lily Park syncline (Dyni, 1968; McKay, 1974) separates the Cross Mountain anticline to the east from the east plunge of the Uinta anticline to the west. This syncline is expressed by sharp folding in the pre-Tertiary rocks and faulting on the east margin. Overlying these rocks, the Bishop (or basal Browns Park of earlier reports) forms a $60-\mathrm{m}$ thick caprock on high terrace remnants on both sides of the valley. These terraces project south across the 
Yampa valley to Twelvemile Mesa. If the slopes of the terraces were projected to the center of the valley, the base of the Bishop would form a gentle swale superimposed on the Lily Park syncline. This swale represents initial dip on the floor of a consequent valley eroded into the syncline, because the source of Bishop debris for the west limb was the Uinta Mountains and the source for the east limb was Cross Mountain, but the swale might have been enhanced by subsequent warping. A post-Bishop tilt to the north, in any event, is unmistakable.

The pre-Bishop Lily Park syncline plunges southward about $120 \mathrm{~m} / \mathrm{km}$ (Dyni, 1968), whereas the superimposed swale structure plunges north; the north plunge is an expression of the widespread post-Bishop tilting of the region, which amounted to about $9 \mathrm{~m} / \mathrm{km}$ in that area and was not sufficient, therefore, to reverse the southerly plunge in the older rocks. One may recall that the crestline of Cross Mountain, which is a relic of the pre-Gilbert Peak, Wild Mountain upland surface, also slopes southward despite the general northerly post-Gilbert Peak (post-Bishop) tilt of the region. This southward slope, like that of the Lily Park syncline, predates the Bishop Conglomerate.

\section{SUMMARY OF POST-BROWNS PARK DEFORMATION}

Tectonic movements in the eastern Uinta Mountains involving the Browns Park Formation have already been mentioned, particularly movements in the Elk Springs area. These movements appear to have been continuations of earlier deformation; rather large-scale deformation preceded, accompanied, and followed deposition of the Browns Park Formation. Some of this deformation has been discussed by Sears (1924a, p. 291) and by Bradley (1936, p. 185), both of whom believed that the major collapse of the Uinta arch was after the deposition of the Browns Park. I believe it was before, inasmuch as it produced the broad, erosionally modified tectonic downwarp into which the Browns Park Formation was deposited-the Uinta arch was depressed hundreds of meters before the Browns Park Formation was deposited. Further deformation then followed.

\section{DIAMOND PEAK AND BROWNS PARK}

Post-Browns Park deformation involved widespread tilting and the reactivation of previously formed faults. Between Diamond Peak and Cold Spring Mountain, for example, the Browns Park Formation extends northwest up the valley of Talamantes Creek along the Uinta-Sparks fault zone, probably as an old valley fill, resting on the older rocks with a sharp angular unconformity. South-dipping drag in the Browns Park indi- cates renewed movement along the fault, down on the south toward the collapsed Uinta arch (Weber, 1971, fig. 4), a continuation of movements that earlier had lowered Cold Spring Mountain relative to Diamond Peak.

Similar faulting in Browns Park is better exposed, better documented, and even more pronounced. Near the head of Browns Park, movement on the Mountain Home fault, the Beaver Creek fault, and other faults reversed the dip in the Uinta Mountain Group, forming drag anticlines and sharply tilting the Browns Park Formation (Hansen, 1965, plate 1, fig. 59; 1957 a,b). Just east of Jesse Ewing Canyon, however, the Mountain Home fault passes beneath the Browns Park Formation without cutting it, showing that the fault antedates the Browns Park Formation. Renewed movement on parts of the Mountain Home fault and the Beaver Creek fault after deposition of the Browns Park Formation, south sides down, indicates further subsidence of the Uinta arch.

The Browns Park Formation is broken by displacements along these and other faults all the way from the head of Browns Park to points north and west of Craig, Colo. (Hansen, 1957a,b; Ritzma, 1959; Tweto, 1976; Rowley and others, 1979). In the Dry MountainDouglas Draw-Vermillion Creek area, in an added complication, the axis of the Browns Park syncline plunges gently northwestward at a rate of about $9.5 \mathrm{~m} / \mathrm{km}$. This plunge also reflects subsidence of the Uinta arch.

\section{YAMPA FAULT}

One of the major structural features on the south flank of the Eastern Uinta Mountains is the faulted Yampa fold bordering the north side of Blue Mountain (figs. 25 and 33). This fault is a low-angle thrust between Hells Canyon and Johnson Draw. At Hells Canyon its dip is about $22^{\circ}$ south and its upper plate is dragged into a sharp bend, the Yampa monocline. Stated differently, the fault is the ruptured synclinal bend of the monocline. Although most of the fault's $1,500-\mathrm{m}$ displacement is Laramide, Sears (1924a, p. 291) ascribed large-scale post-Browns Park movement to it and invoked this movement to explain the course of the Yampa River. I know of no clear evidence of any post-Browns Park offset; evidence to the contrary near the western end of the fault indicates little or no movement since the Bishop Conglomerate was deposited.

Dyni (1980), however, found evidence of inter- and post-Browns Park deformation east of the Yampa monocline in the Elk Springs area, some of which he attributed to recurrent movements on growth faults. Near the eastern terminus of the Yampa fault and 
monocline the Bishop Conglomerate has been displaced by renewed warping on the monocline (fig. 33), but whether or not this movement was post-Browns Park in age is uncertain. Structure contouring based on abundant remnants of Bishop Conglomerate indicates that post-Bishop warping is superimposed on preexisting structural features. In T. 5 N., R. 99 W. and R. $100 \mathrm{~W}$., a noselike swing of the contours (fig. 33) coincides with the plunging south branch of the Yampa monocline. Just to the north, in T. 6 N., a synclinal reentrant in the contours coincides with the north branch of the Yampa fault and its synclinal extension. These features suggest resurgence of older structures. Here the Bishop and the subjacent Gilbert Peak erosion surface have been warped about $120 \mathrm{~m}$. Inferred postBrowns Park warping on the nearby Deerlodge monocline (see next section) suggests possible warping of that age at the eastern end of the Yampa structure also.

West of Hells Canyon, however, the Yampa fault dies out, and its monoclinal extension is truncated by the Gilbert Peak erosion surface and the Bishop Conglomerate. (See fig. 29.) Some minimal post-Bishop dis- tortion of the surface across the monocline is possible in this area, but it isn't obvious. At any rate, because the fault does not displace the Bishop Conglomerate, the trough-like or bench-like outer canyon of the Yampa River between Douglas Mountain on the north and Blue Mountain on the south is a product of erosion, not faulting (fig. 34). The trough resulted from the differential erosion of soft Triassic and younger rocks from the downthrown side of the Yampa fault or monocline in post-Bishop time.

Sears (1924a, p. 303; 1962, p. 23-24) visualized a new Yampa River flowing west into a drag syncline just north of the Yampa fault, but inasmuch as the Gilbert Peak surface and the Bishop Conglomerate extend unbroken across the Yampa monocline west of Hells Canyon near Harpers Corner, the fault zone and downwarp could not have been the avenue for the Yampa River. The present river is far north of the fault zone and, because of the low southerly dip of the Yampa fault along most of its length, moreover, any gravitative "collapse" of the downthrown (north) side as visualized by Sears is unlikely. Unaware of its low southerly dip,



FIGURE 34.-View from the rim of Johnson Draw (foreground) west-northwest along the escarpment of the Yampa fault, Moffat County, Colorado. In the distance the fault becomes a monocline. On the distant ridge, center and upper right, the Gilbert Peak erosion surface capped by Bishop Conglomerate extends unbroken across the fault/moncoline trace. The broad, troughlike valley in the middle distance to the right of center has been differentially eroded from the soft Triassic and younger rocks that once filled the area. Yampa Canyon is at the extreme right. 
Sears assumed, as Powell had before him, that the Yampa fault was a high-angle normal fault. Following Sears' lead, other authors have similarly concluded that the Yampa fault is the southern boundary of the socalled Browns Park or Uinta Mountain graben, in the mistaken belief that the Yampa fault dips north. This graben simply does not exist.

\section{DEERLODGE MONOCLINE}

Geomorphic relationships along the Little Snake and Yampa Rivers suggest warping on the Deerlodge monocline during or after Browns Park deposition. This monocline is the short, abrupt fold that terminates the Uinta uplift on the east (Hansen and others, 1984) and provides the dramatic entry into Yampa Canyon from Deerlodge Park (fig. 13). Just upstream from Deerlodge Park along the Little Snake River, a basal conglomerate beneath the Browns Park Formation between Cross Mountain and the eastern Uintas (p. 32) indicates through drainage by a vigorous stream in that area in a canyon-like setting at the onset of Browns Park deposition. Where this drainage went is problematical, but it almost certainly turned west along the present Yampa Canyon, because egress in other directions is blocked by higher ground, even though there is little likelihood that a canyon as deep and narrow as the present one could have persisted since Miocene time. A south-flowing course toward the White River looks plausible on a planimetric map, but geomorphic evidence is against it. More likely, the drainage turned west into a then-shallower, more juvenile Yampa Canyon, which deepened as the resurgent Deerlodge monocline rose beneath it (or as the connecting Lily Park syncline sank).

The rise of the monocline would have inhibited drainage upstream and would have abetted the aggradation that attended the deposition of the succeeding Browns Park Formation. This reconstruction of events accords well with Hunt's concept of anteposition $(1967,1969)$, whereby a drainage temporarily blocked by a rising uplift overtops the obstruction by aggrading its bed, then resumes its previously established course. The presence of loose Browns Park sandstone at rim level on Bishop Conglomerate upstream from Yampa Canyon (Dyni, 1980, map) adds credence to this hypothesis.

East Cactus Flat, which truncates the Deerlodge monocline, slopes gently southward-its rim is highest next to Yampa Canyon. The slope probably postdates the entrenchment of the river; otherwise the river should have migrated downslope to the south, away from its present position. The southerly slope probably is a manifestation of resurgence of the Deerlodge monocline during or after the deposition of the Browns Park Formation.

\section{DRAINAGE DEVELOPMENT}

Drainage off the eastern Uinta Mountains formed concomitantly with Laramide uplift, and the gradual degradation of the mountains in Paleocene and Eocene time produced immensely thick deposits of clastic sediment and carbonates in the adjoining basins. Drainage at that time was centrifugal, away from the mountains in all directions, unlike the modern drainage, and it remained largely so until after the deposition of the Bishop Conglomerate (fig. 35). One exception was the structurally controlled drainage of Blue Mountain, where the Wolf Creek-Mud Springs Draw drainage was controlled by the east-west folds and faults on Blue Mountain. Even that drainage was consequent to the structural trough between the subsidiary folds of the Blue Mountain highland. The distribution of Bishop Conglomerate shows that Wolf Creek was constrained, then as now, by the bounding upwarps of Blue Mountain. Modern Wolf Creek and Mud Springs Draw, flowing across Bishop Conglomerate, are re-incising themselves into the sub-Bishop bedrock.

As drainage from the mountains flowed out toward the basins, it deposited the Bishop Conglomerate in broad, sheetlike fans on the subjacent Gilbert Peak erosion surface. The present major streams of the area obviously did not yet exist; their courses are younger then the pedimentation and the alluviation that produced the Bishop Conglomerate.

Deposition of the Bishop Conglomerate ended when renewed deformation terminated the long period of crustal stability that followed Laramide uplift. One consequence was a drastic overhaul of the drainage regime. Gravitative movements on the zone of faults along Red Canyon and Browns Park tilted the whole crestal region and south flank of the range northward and eastward, deforming the Gilbert Peak erosion surface and lowering the crestline as much as one and a half kilometers. These movements began in late Oligocene time and lasted intermittently through the Miocene and, perhaps, the Pliocene. Some faults predated the Browns Park Formation; others displaced and dragged it to steep angles. Some faults have had Quaternary movements. At the east end of the range the lowering of the Bishop below present drainage formed a broad downwarp that became a catchment basin for the Browns Park Formation. Between Browns Park and the Uinta fault, the north flank of the range was tilted unevenly southward.

All these crustal movements helped set the stage for the drainage changes that followed. Much of the runoff that had flowed from both flanks of the range toward the Tertiary basins was reversed and became tributary to the newly forming valley of Browns Park. The new 

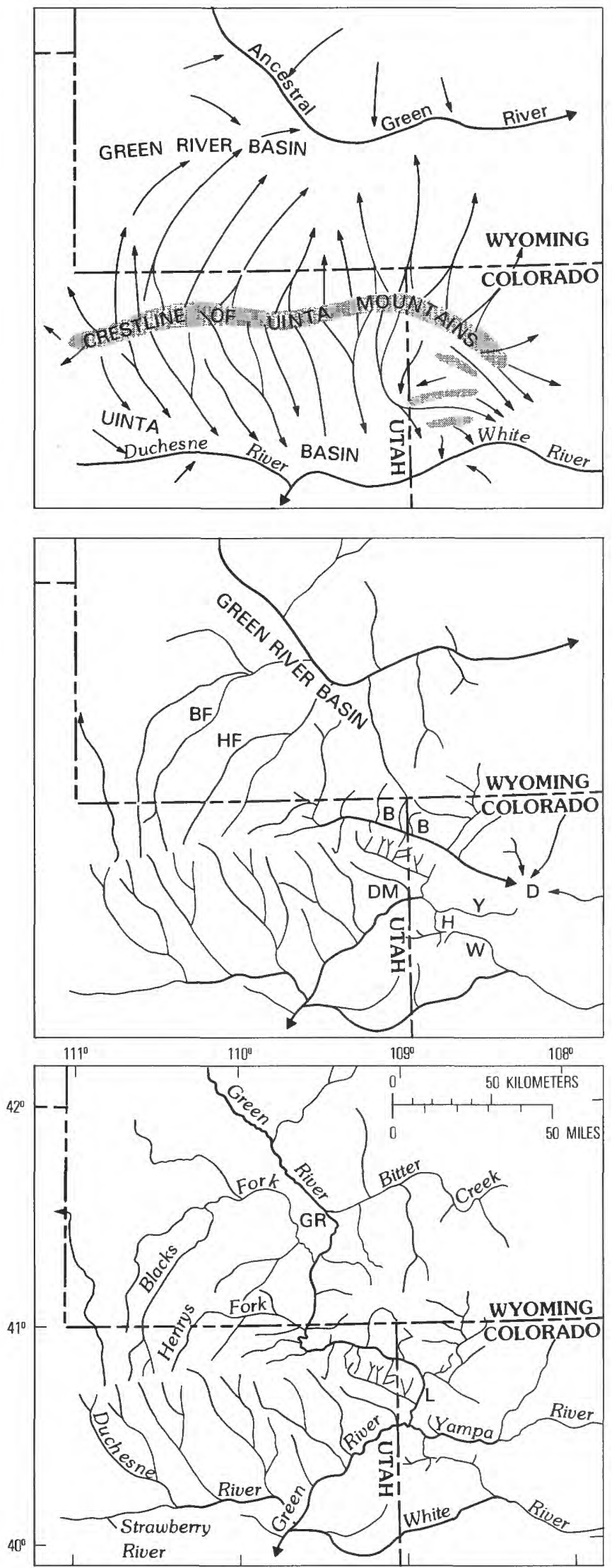

drainage lines in Browns Park then carried the combined runoff eastward to the downwarp in the LayMaybell-Little Snake area. The former crest of the range was now a deepening valley that ultimately would carry the full flow of the Green River. As discussed later, the Green was eventually diverted south from Browns Park into Lodore Canyon.

\section{ADJUSTMENTS ON THE SOUTH FLANK-IN THE POT CREEK AREA}

Former southward drainage south of Browns Park and Red Canyon is indicated by the barbed tributary patterns of all the major valleys between Cart Creek (fig. 36) and Lodore Canyon (Kinney and others, 1959; Ritzma, 1959, p. 87; Hansen and others, 1960, p. B258; Hansen, 1965, p. 174; 1969a, p. 34; Hunt, 1969, p. 97). During Bishop time all these valleys drained into the Uinta Basin and contributed detritus to the Bishop Conglomerate (fig. 37). All still contain Bishop Conglomerate, consisting mostly of coarse, nearly white, friable pebbly sandstone and conglomerate. As these fills merged southward they formed an extensive bajada on the south flank of the range (Hansen and others, 1981).

With northerly and easterly tilting, however, all these streams stagnated and partly reversed their flow directions, leaving barbed tributaries. In part these reversals were caused simply by capture due to tilting. For example, Cart Creek, Gorge Creek, and Jackson Creek were captured by vigorous north-flowing streams emptying into Red Canyon through deep, narrow tributary canyons. All the reversed streams, in

Figure 35. - Steps in the development of the Green River drainage system, telescoped in time and generalized. Details in text.

Top.-Late Oligocene time. Diagrammatic drainage off the Gilbert Peak erosion surface and across the Bishop Conglomerate into the adjacent basins. At this stage the Bishop formed a nearly continuous bajada around the flanks of the Uinta Mountains.

Center.-Latest Oligocene to early Pleistocene time. Subsidence and northeasterly tilting have redirected the drainage in the eastern part of the range. Note new drainage through Browns Park (B) along the former crestline, leading to the downwarped area (D) at the east end of the range. Note reversals of drainage direction on the northeast flank and the new southeasterly drainage at Diamond Mountain (DM). Vigorous headward erosion into the Green River Basin from the south is threatening the eastflowing ancestral Green and its northeast-flowing tributaries, Blacks Fork (BF) and Henrys Fork (HF). Hells Canyon (H) has captured the headwaters of Wolf Creek (W). Yampa Canyon (Y) is eroding headward toward D.

Bottom.-Present drainage. The southeasterly drainage along the Uinta axis spilled across the range, in late Miocene or early Pliocene time, at Lodore Canyon (L). The Green River was captured at Green River, Wyo. (GR), in the early Pleistocene. Black Fork and Henrys Fork have been redirected southward. Note the barbed confluence of Bitter Creek with the Green River. 


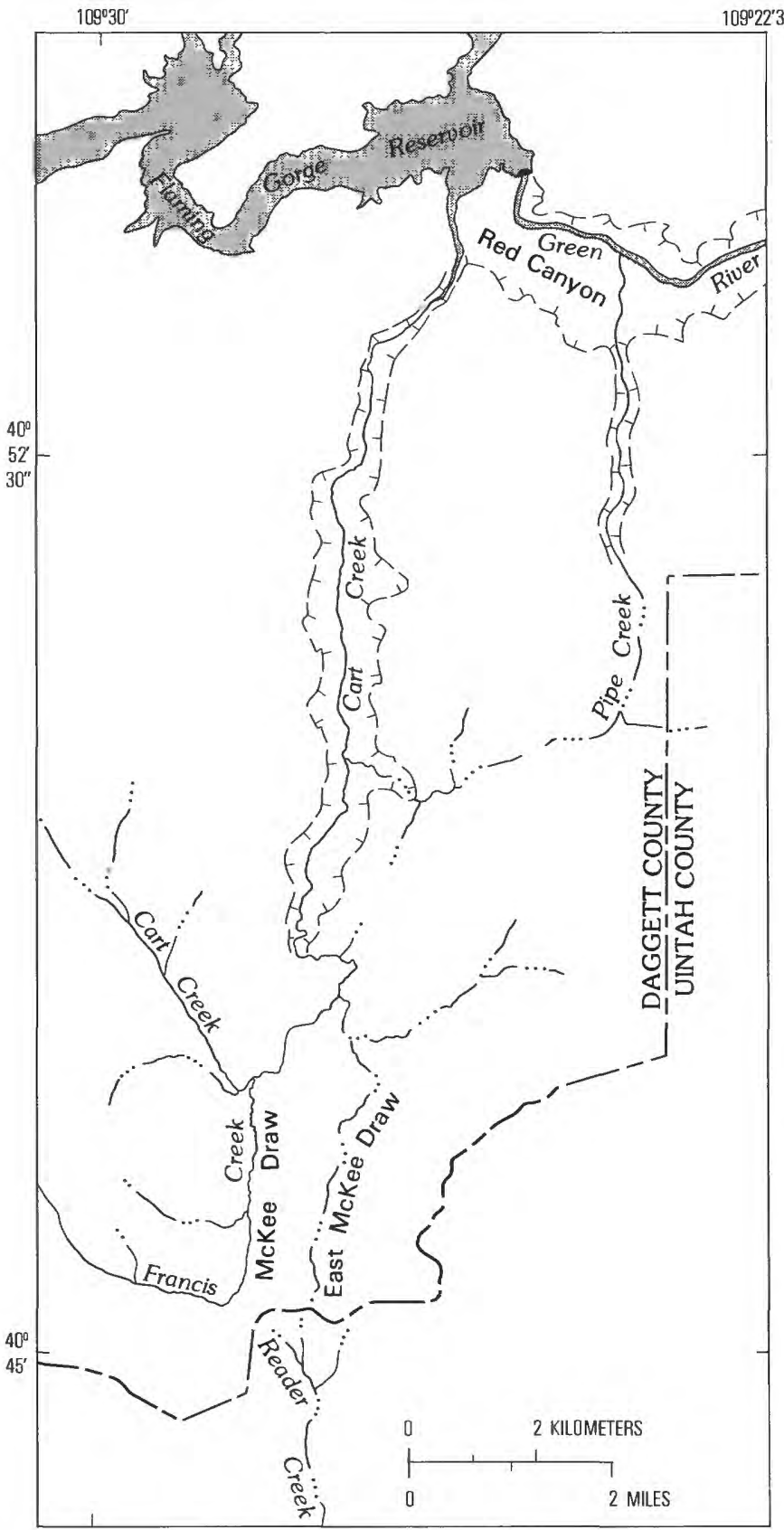

Figure 36.-Drainage map of the Cart Creek area, showing barbed headwater tributaries that formerly flowed south to Reader Creek. These tributaries meander sluggishly through McKee Draw and East McKee Draw before plunging into the Cart Creek canyon, shown by hachures (hachures coincide with canyon rims).

fact, now pass through such canyons before joining the Green. Most of the valleys at some midpoint contain low divides in Bishop Conglomerate, the northerly reaches flowing to Red Canyon or Browns Park and the southerly reaches to Pot Creek. A person can cross such a divide by automobile without realizing that the drainage direction has changed 180 degrees. Similar low divides separate the drainages of Pot Creek and Diamond Gulch.

Pot Creek and Diamond Gulch are post-Bishop drainages that formed by the diversion of southward runoff into east-southeasterly courses after regional tilting. Because of the concavity of the original Bishop profile, tilting created new low points along the formerly southflowing streams, as shown diagrammatically by figure 38. Pot Creek and Diamond Gulch sought out these low points and consequently funneled the runoff toward the east-southeast. The near coincidence of Pot Creek and Diamond Gulch with fault lines, however, suggests that their drainage direction was influenced partly by faulting. I visualize south-building alluvial fans gradually rising toward and locally overtopping low places at fault lines in the interfluves. With tilting, drainage found its way across these partly buried interfluves.

Drainage adjustments are still taking place and, on a geomorphic time scale, Pot Creek itself is threatened with imminent capture by Crouse Creek (Hansen and others, 1981). Crouse Creek heads within a few hundred feet of Pot Creek, has the advantage of a steeper gradient than Pot Creek, and is cutting rapidly downward into the intervening divide of soft Bishop Conglomerate (mostly friable sandstone at that locality). Pot Creek, on the other hand, flows alternately across the Bishop Conglomerate and the Uinta Mountain Group and is held at grade by numerous thresholds of hard red quartzite. If left to itself, the entire discharge of Pot Creek upstream from the divide will eventually flow north into Crouse Creek. The capture of Pot Creek, in fact, has been partly fulfilled artificially by a diversion ditch that directs water from Pot Creek across the low divide into Crouse Creek to irrigate hay fields in Browns Park. A narrow trench 10-15 $m$ deep has already been eroded into the divide.

\section{ADJUSTMENTS ON BLUE MOUNTAIN}

Middle Tertiary drainage adjustments on Blue Mountain parallel those of the Pot Creek area in time and style. The pre-tilt drainage flowed east down Wolf Creek in a valley floored with Bishop Conglomerate. Hells Canyon, which drains north to the Yampa River, has captured most of the headwaters of Wolf Creek and in so doing has greatly expanded its watershed at the expense of Wolf Creek (fig. 39). Hells Canyon is a steep, narrow gorge that drops nearly $600 \mathrm{~m}$ in about $11 \mathrm{~km}$ at an overall rate of $38-57 \mathrm{~m} / \mathrm{km}$; the gradient steepens locally to as much as $75 \mathrm{~m} / \mathrm{km}$. Wolf Creek has a gradient of only about $15-19 \mathrm{~m} / \mathrm{km}$. Mud Springs Draw, Spike Hollow Draw, and Bobcat Draw are sharply barbed former tributaries of Wolf Creek. 




FiguRE 37.-Distribution of Bishop Conglomerate (shaded), anomalous present drainage pattern, and barbed tributaries of north-flowing streams in Pot Creek area. Hachures indicate canyons. Note how close heads of Jackson Creek and Crouse Creek are to Pot Creek. Pot Creek is held at grade by the numerous crossings of the Uinta Moutain Group (unshaded), and its capture by Crouse Creek is imminent at point shown by arrow.

Turner Creek, a former reach of Wolf Creek, has been reversed and is now separated from Wolf Creek by a low divide. Northerly tilt probably shifted the hydraulic advantage to Hells Canyon. Farther upstream, northflowing Meadow Creek captured the headwaters of $\mathrm{K}$ Creek, probably at about the same time.

Johnson Draw, which once drained south independently into Wolf Creek, now drains north to the Yampa
River via Johnson Canyon, a gorge that resembles Hells Canyon but is smaller. Johnson Draw heads only $11 / 2 \mathrm{~km}$ from Wolf Creek at a wide low pass in Bishop Conglomerate, then flows $11 \mathrm{~km}$ north to the Yampa. A few kilometers to the east, Bear Valley Draw, shown on figure 26, still drains into Wolf Creek, but part of its headwaters has been diverted to the Yampa via Bear Draw through a deep gorge cut in the Madison 

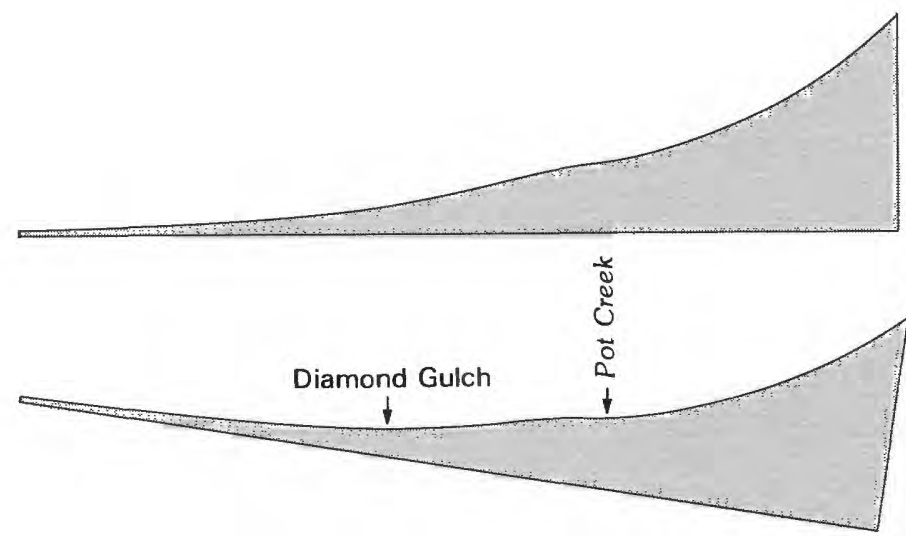

FIGURE 38.-Effect of tilt on the low point of a concave-upward profile. New low points are indicated by arrows on tilted profile. The local flattening of the original profile at the future site of Pot Creek is attributed to a constriction in the valley upstream from a belt of resistant Precambrian rock across the drainage line.

Limestone. Bear Valley is being threatened by Thanksgiving Gorge at East Bear Valley Draw, but capture is not yet imminent.

\section{ADJUSTMENTS ON THE NORTH FLANK}

Drainage adjustments on the north flank of the Eastern Uinta Mountains, north of the anticlinal axis (fig. 40), have had far-reaching geomorphic consequences. Many adjustments were imposed by the deformation that ended the Bishop depositional episode. Erosion in the southern Green River Basin since the end of the Bishop episode in late Oligocene time has been extensive, and evidence for ensuing drainage changes has been partly lost to erosion. In brief, a reversal of the regional gradient, accompanied by a large-scale redirection of the drainage, was caused by the foundering of the Uinta arch in late Oligocene and early Miocene time.

From the time Lake Gosiute disappered (middle Eocene) until the foundering of the Uinta arch (late Oligocene), the drainage of the southern Green River Basin was northward, away from the Uinta Mountains. The northerly gradients on Bishop-capped remnants of the Gilbert Peak erosion surface and the northward fining of the gravels leave no doubt about the direction. The northward drainage must have arisen south of the exposure area of the Red Creek Quartzite, as cobbles and boulders from the Red Creek and from the Uinta Mountain Group are abundant in the Bishop Conglomerate on Little, Miller, and Pine Mountains and as far north as Aspen Mountain. The drainage divide was well south of the Uinta fault, for the Red Creek Quartzite is truncated south of the fault by the Gilbert Peak erosion surface. The crestline must have been as far south as Browns Park, along the axis of the Uinta anticline, because the reconstructed profile of the Gilbert Peak surface projects into the air above Browns Park. The coarseness of the Bishop, furthermore, indicates that its source to the south had strong relief. Bradley (1936, p. 177) suggested that the master drainage was eastward or northeastward out of the Green River Basin, possibly toward the ancestral Platte River, a view endorsed by Ritzma $(1959$, p. 87$)$ and elaborated by Hansen (1969b). Sears (1924a) had hinted at it decades earlier.

As pointed out previously (p. 32), the shift in drainage direction along the mountains followed the deposition of the Bishop Conglomerate and preceded the deposition of the Browns Park Formation, because the Browns Park Formation contains abundant clasts derived from sources to the north. New south-flowing drainage lines must have begun to form all along the north flank of the range concomitantly with tilting. With modifications, these lines persist in the modern drainage. The master drainage was diverted much later (p. 31).

\section{FLAMING GORGE AREA}

The foundering of the Uinta arch almost surely played a critical part in redirecting the drainage of the Green River Basin toward the south and in establishing the present Green River as the master stream of the basin. Some idea of the extent of the subsidence at Flaming Gorge, where the Green enters the mountains, ean be had by comparing the present height of Bear Mountain with Cedar and Little Mountains in Wyoming (fig. 41); all three of these are remnants of the Gilbert Peak erosion surface. (Cedar and Little Mountains are also capped by Bishop Conglomerate; Bear Mountain is not). In longitude, Bear Mountain is about half way between Cedar and Little Mountains, and it stands about $18 \mathrm{~km}$ to the south. The elevation of Cedar Mountain approaches $2,620 \mathrm{~m}$, and Little Mountain exceeds $2,774 \mathrm{~m}$. A point on the restored Gilbert Peak surface halfway between at their latitude would be about 2,700 $\mathrm{m}$, or about $2,670 \mathrm{~m}$ if $30 \mathrm{~m}$ is subtracted for an assumed capping of Bishop Conglomerate, which is about $30 \mathrm{~m}$ thick on Twin Buttes, $4.8 \mathrm{~km}$ to the north. Bear Mountain, however, reaches only $2,356 \mathrm{~m}$, about 300 $\mathrm{m}$ lower than the projected surface midway between Cedar and Little Mountains. Originally, though, Bear Mountain was higher than the restored midpoint. If the restored pre-tilt gradient of the Gilbert Peak erosion surface (there assumed to be about $38 \mathrm{~m} / \mathrm{km}$ ) were projected south to Bear Mountain, it would reach about 3,350 m. Thus, the Gilbert Peak surface at Bear Mountain probably has been lowered at least $975 \mathrm{~m}$. That 


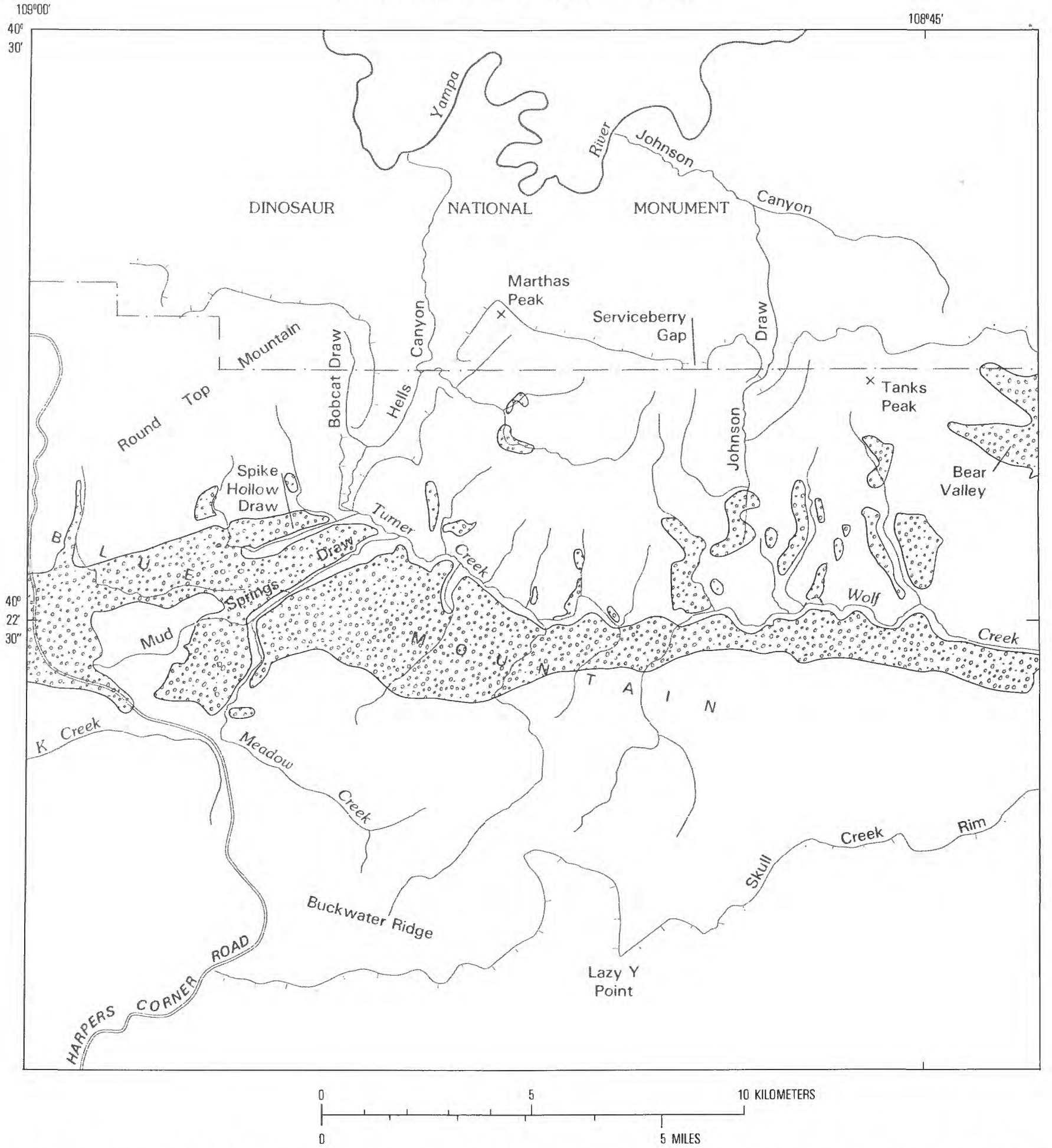

Figure 39.-Drainage map of the Blue Mountain area. Stippling indicates Bishop Conglomerate. Note how former drainage of Wolf Creek has been diverted into Hells Canyon, reversing the direction of Turner Creek. Meadow Creek formerly flowed into K Creek. Note barbed tributaries of Johnson Draw.

amount of lowering requires a back tilting toward the mountains of about $17 \mathrm{~m} / \mathrm{km}$, and with that amount of tilt, a reversal of the drainage should not be surprising.
In fact, the new southward and eastward drainage should have been vigorous and should have agressively enlarged its watershed at the expense of disadvantaged 


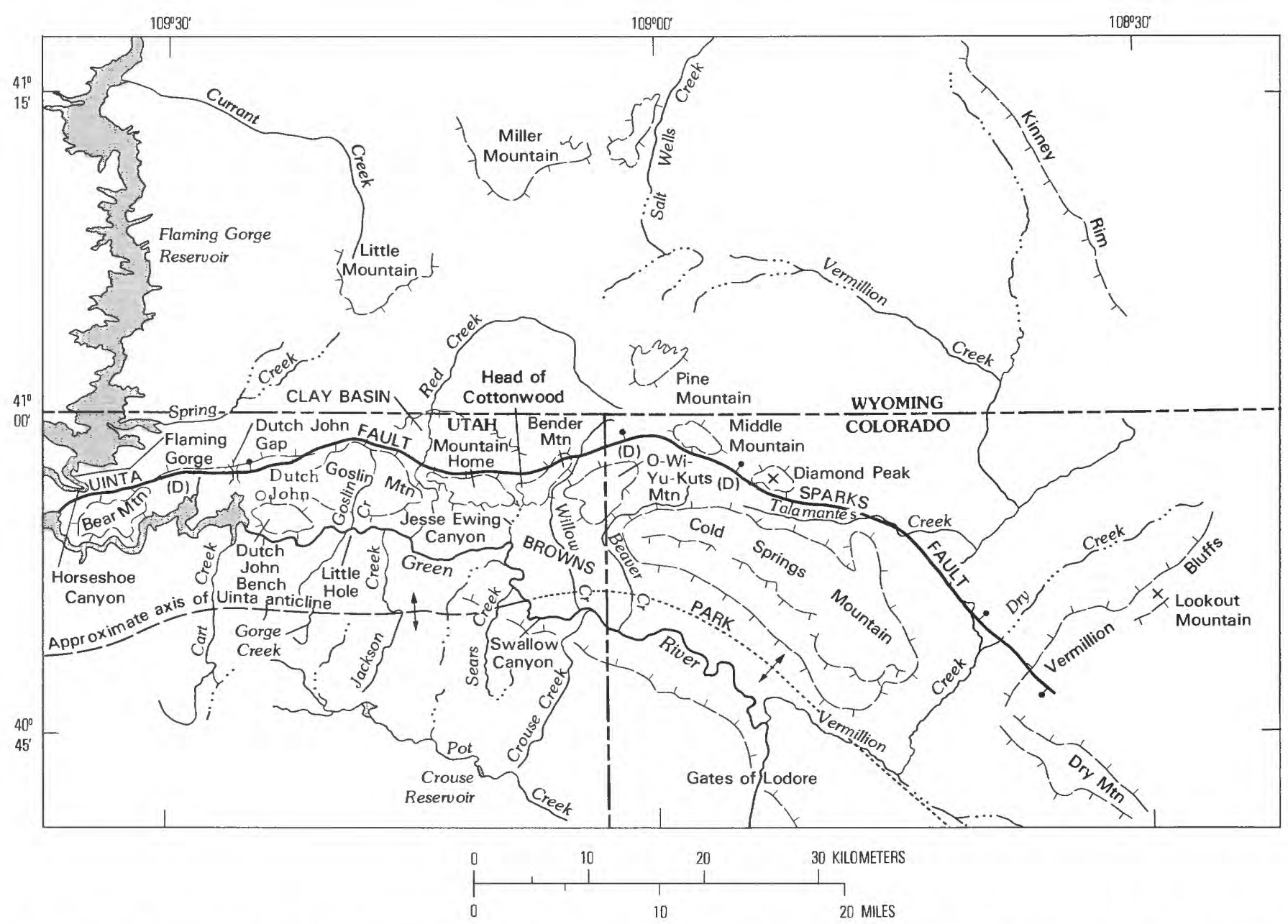

Figure 40.-Principal hills and drainages of northeast flank of Uinta Mountains and vicinity and their relationship to the Uinta anticline and the Uinta-Sparks fault zone. Bar-and-ball symbol indicates Laramide downthrow; (D) indicates post-Bishop downthrow; hachures outline mountains and escarpments. Notice at upper center of the map how Salt Wells Creek has captured the headwaters of Vermillion Creek.

north-flowing streams nearby. The flow through Red Canyon toward Browns Park should have rapidly extended its watershed north into the Green River Basin, capturing such streams as Henrys Fork and Sage Creek in the process. Just when it captured the master drainage of the basin, thereby greatly shifting the position of the Continental Divide, is uncertain, but it probably did so in Pleistocene time (Hansen, 1969b; Hansen and others, 1983). Such a momentous capture, diverting and acquiring the headwaters of the Platte River, would have vastly enlarged the competence and erosive capacity of the system. The effect on the Platte should have been the opposite-aggradation and reduced competence.

Drainage changes in the various tributaries of the Green River on the north slope of the Eastern Uinta Mountains since Bishop time have been outlined by several investigators (Sears, 1924a; Bradley, 1936; Ritzma,
1959; Hansen and others, 1960; Hansen, 1965, 1969a, $1969 \mathrm{~b}, 1984)$. In brief, drainage quickly adjusted to the topographic changes brought on by the foundering of the Uinta arch, and the earliest new stream courses were largely consequent down the new slopes.

Subsidence and topographic distortion caused by the foundering diminished gradually westward to a minimum. Drainage west of Flaming Gorge continued to flow northward, but all of it as far west as Henrys Fork was eventually captured by structurally controlled subsequent drainage that flowed directly to the Green River in response to the new gradients (Hansen, 1965 , p. 175-180).

East of Flaming Gorge the topographic dislocations were severe, and the resultant drainage changes were correspondingly drastic. New south-flowing consequent streams included Spring, Goslin, Red, Willow, Beaver, and Vermillion Creeks, the Little Snake River, and 


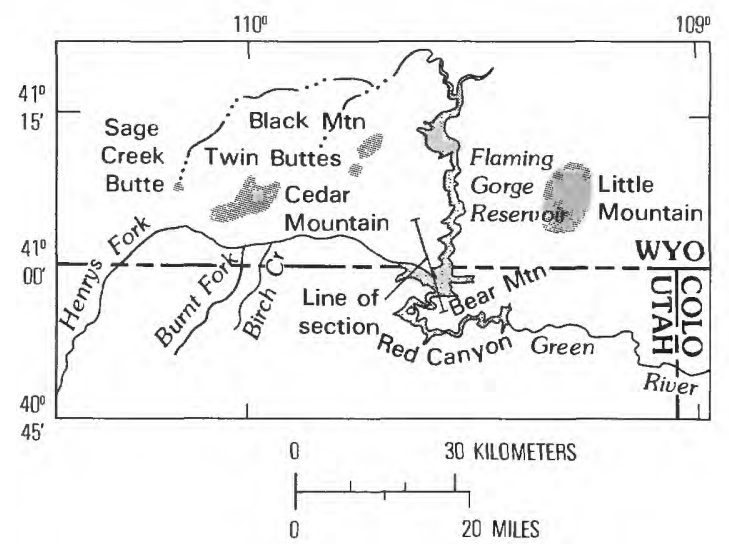

NORTH

SOUTH

ELEVATION

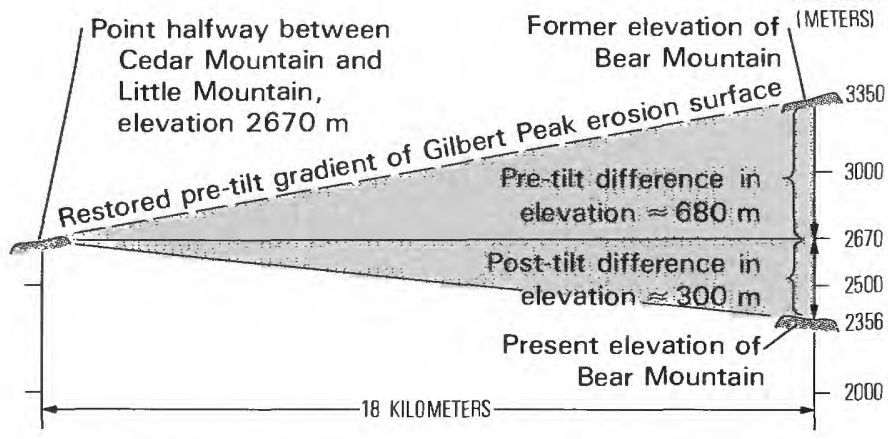

FIGURE 41.-Diagram showing subsidence of Bear Mountain and reversal in gradient of Gilbert Peak erosion surface north from Bear Mountain. The restored gradient is assumed to have been a uniform $38 \mathrm{~m} / \mathrm{km}$, although it probably was actually concave upward. In any event, subsidence of the magnitude indicated would have drastically altered the drainage directions across the area. Vertical scale is $\mathbf{1 0}$ times horizontal scale.

many lesser streams. (Incidentally, remnants of the Browns Park Formation deposited within the valleys of Vermillion Creek and the Little Snake River are confirmatory evidence that southerly directed drainage and hence southerly tilting predated the Browns Park Formation). Further realinements took place along some of these streams as they adjusted to the structure of the underlying bedrock and as subsequent drainage developed along belts of nonresistant rock. Spring Creek, for example, was later diverted west into a strike valley in the Hilliard Shale (Cretaceous), leaving its initial course high and dry at Dutch John Gap (Ritzma, 1959, fig. 8C; Hansen, 1965, fig. 67). (Dutch John Gap is a conspicuous wind gap just northwest of Dutch John, Utah).

\section{VERMILLION CREEK AND IRISH CANYON}

Changes in the course of Vermillion Creek at the southeast end of Cold Spring Mountain have been described briefly by Sears (1924a, p. 298). With a drainage area of more than $2,600 \mathrm{~km}^{2}$, Vermillion Creek has by far the largest basin of the south-flowing tributaries of the Green between Flaming Gorge and the Little Snake River. Vermillion Creek crosses the flank of the Uinta arch in a narrow canyon about $215 \mathrm{~m}$ deep. Sears attributed this canyon, correctly I think, to superimposition down through a former cover of the Browns Park Formation. However, the broad basin of Vermillion Creek upstream from the canyon plainly was excavated before the Browns Park Formation was deposited in it. The present valley may have evolved through a process of cutting, back filling, and renewed cutting, perhaps by the mechanism of antepositoin, as postulated by Hunt $(1956,1967,1969)$ for many stream valleys of the West. Sears also pointed out the probability that Vermillion Creek formerly flowed through nearby Irish Canyon (fig. 42) but was captured by a tributary of the "East Fork of Vermillion Creek." (The East Fork is now called Dry Creek.) With that capture, Irish Canyon was abandoned by perennial drainage and is now a dry but impressive beheaded valley, $6.5 \mathrm{~km}$ long and nearly $300 \mathrm{~m}$ deep.

Sears did not elaborate on the origin of Irish Canyon, but he noted that Irish Canyon's downstream extension, Bull Canyon, though incised into the Uinta Mountain Group, has undoubtedly been superimposed. The Browns Park Formation still exists at the head and mouth of Bull Canyon and on both rims. Whether or not the Browns Park Formation also once covered the rims of Irish Canyon, however, is doubtful. The head of the canyon truncates a bermlike remnant of a pediment that flanks Cold Spring Mountain on the northeast. Just $2.4 \mathrm{~km}$ farther north the pediment passes beneath a basal conglomerate of the Browns Park Formation that, in turn, underlies typical Browns Park sandstones. Soon after the pediment formed, the Browns Park Formation probably was deposited on it. Irish Canyon, which cuts the pediment, probably is younger, therefore, than the nearby Browns Park Formation. The slope of the pediment, moreover, is wrong for drainage into Irish Canyon. A hypothesis that would not require superposition of Irish Canyon down through the Browns Park Formation is as follows:

Irish Canyon, like other north-flank drainageways, began to form with the onset of tilting and collapse of the north flank. Eroding headward across the Uinta Mountain Group and the lower Paleozoic rocks, Irish Canyon then uncovered the soft Morgan Formation and started to excavate a strike valley on the northeast side of Cold Spring Mountain over the present upper reach of its canyon. Meanwhile, another south-flowing drainage was excavating Vermillion Creek basin. On the southwest side of the basin —on the northeast flank of Cold Spring Mountain-the pediment that is preserved today as the aforementioned berm was forming at that 


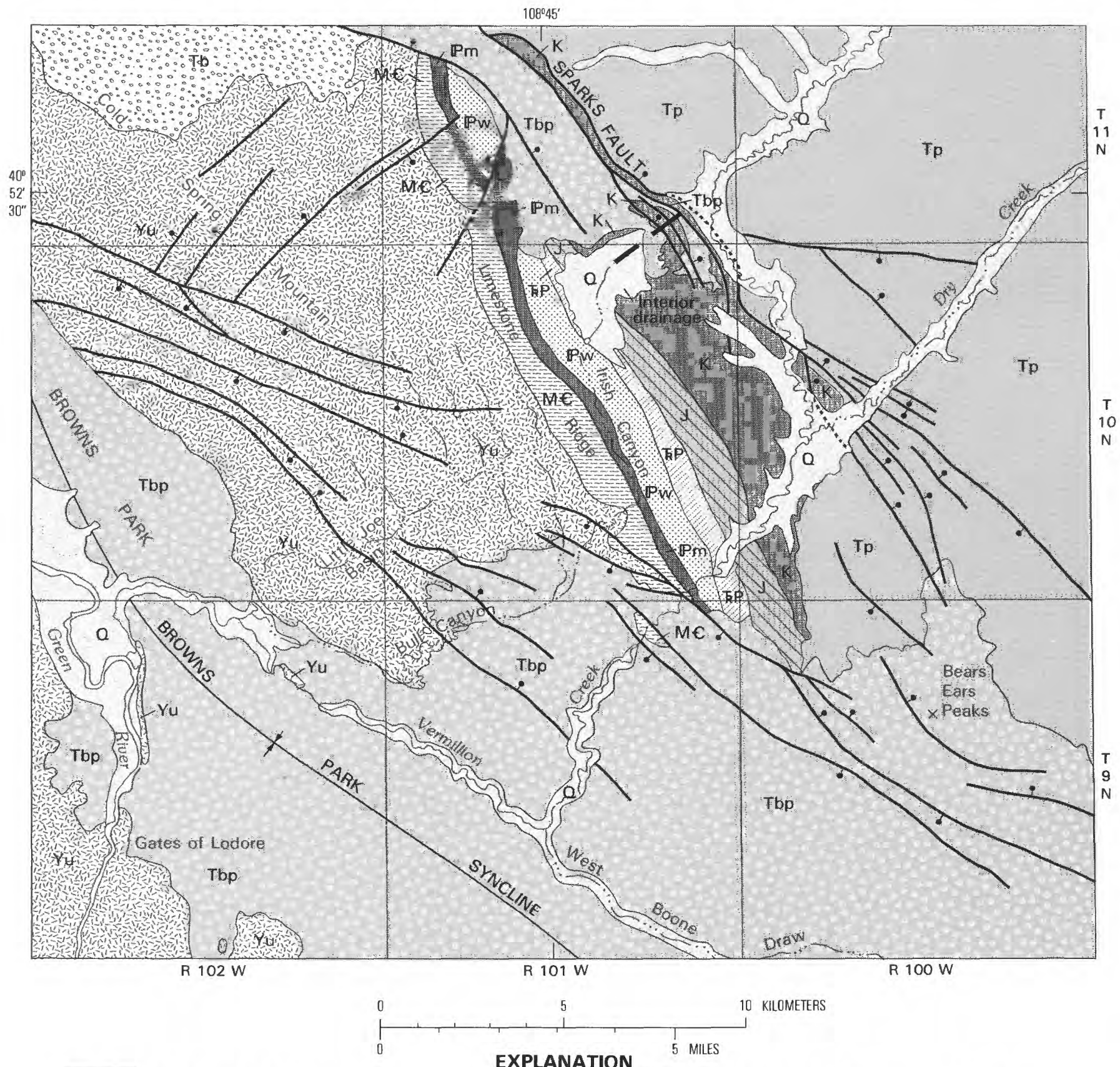

\begin{tabular}{|c|c|}
\hline $\mathrm{Q}$ & QUATERNARY DEPOSITS \\
\hline Top & BROWNS PARK FORMATION (TERTIARY) \\
\hline$\therefore$ 每bo & BISHOP CONGLOMERATE (TERTIARY) \\
\hline Tp & PALEOGENE ROCKS \\
\hline$\sqrt{1}$ & CRETACEOUS ROCKS \\
\hline & JURASSIC ROCKS \\
\hline
\end{tabular}

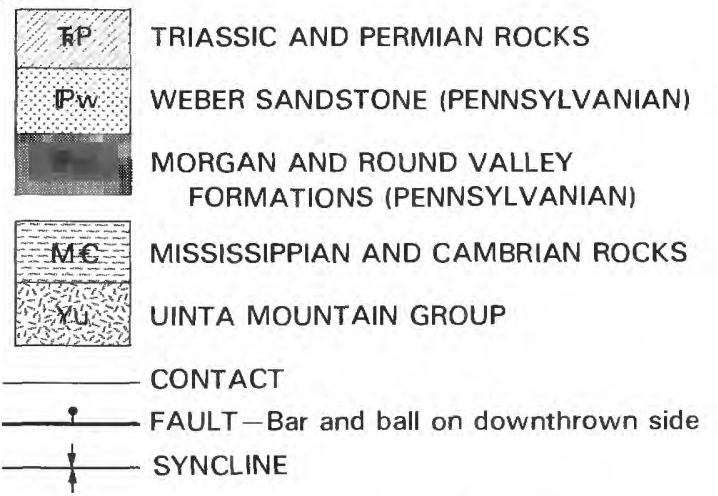

FigURE 42.-Geologic map of Vermillion Creek area affected by the beheading of Irish Canyon. Heavy dashes mark wind gap at head of Irish Canyon. Geology modified from Rowley and others (1979). 
time also, graded to the floor of Vermillion Creek basin. The Browns Park Formation soon began to accumulate on the pediment, on the floor of Vermillion Creek basin, and in the valley of Browns Park below Irish Canyon. Irish Canyon continued to erode headward, finally truncating the pediment along the strike of the Morgan Formation, leaving the stranded berm. Perhaps it then extended its headwaters north to become the upper reach of ancestral Vermillion Creek.

At that time, the level of Irish Canyon was about $425 \mathrm{~m}$ above modern drainage in the Vermillion Creek basin, as indicated by the altitude of its rim. Ancestral Vermillion Creek would have continued to flow through Irish Canyon until a tributary of Dry Creek beheaded the canyon and set the present drainage pattern. Dry Creek, which probably was flowing on the Browns Park Formation at that time, would have had an erosive advantage over Irish Canyon, which had to cross the quartzites of the Uinta Mountain Group and the resistant Paleozoic limestones.

Downstream from the point of capture, the southeast-trending reach of Vermillion Creek meanders in a trench that parallels, crosses, and recrosses the Sparks fault in a way that suggests a causative relationship between faulting and drainage. The fault is downthrown to the northeast, and the Browns Park Formation is tilted northeastward by drag in the upthrown block. Late movement on the fault thus postdates the Browns Park Formation. This movement moreover was directly athwart ancestral Vermillion Creek and was parallel to the capturing tributary of Dry Creek. It therefore would have inhibited the flow of ancestral Vermillion Creek while encouraging headward erosion by the capturing tributary. Capture, therefore, probably shortly followed movement.

The capture of Irish Canyon must postdate the diversion of the Green River into Lodore Canyon, because the Green River is the base level of Vermillion Creek and because the wind gap at the head of Irish Canyon, at an altitude of about $2,035 \mathrm{~m}$, is nearly $300 \mathrm{~m}$ lower than the rims of Lodore Canyon at the Gates of Lodore. The diversion of the Green River into Lodore Canyon should have rejuvenated all upstream drainage. The capture of Irish Canyon probably was an early Pleistocene event, inasmuch as it significantly postdated the deposition of the Browns Park Formation and inasmuch as the wind gap at its head is only about $180 \mathrm{~m}$ higher than nearby modern Vermillion Creek. The latest ground-breaking movement on the Sparks fault, therefore, may be as recent as early Pleistocene. An earthquake on September 24, 1983, strengthens the case for Quaternary movement. This earthquake, of magnitude 4.2, was centered beneath Cold Spring Mountain at lat $40.8^{\circ}$ N., long $108.8^{\circ}$ W. (John Minsch, U.S. Geological Survey, oral commun., October 3, 1983), and it may have been caused by a movement on the Sparks fault, which dips southwestward beneath Cold Spring Mountain.

Bull Canyon, like Irish Canyon, also could not have been eroded until after the diversion of the Green River into Lodore Canyon, inasmuch as the rims and floor of Bull Canyon are much lower than the rims of Lodore. Bull Canyon has an average depth of about $75 \mathrm{~m}$, and at its mouth its floor is only about $75 \mathrm{~m}$ above its base level downstream at nearby Vermillion Creek. Bull Canyon, therefore, must have been incised largely in later Pleistocene (early Wisconsin?) time, well after the beheading of Irish Canyon. Despite the loss of its Irish Canyon headwaters, Bull Canyon still drains about $30 \mathrm{~km}^{2}$ of steep terrain on Cold Spring Mountain, much of it possibly gained at the expense of the drainage of Little Joe Basin.

\section{PHYSIOGRAPHIC SETTING AND DEVELOPMENT OF LODORE CANYON}

For more than 100 years geologists have pondered the course of the Green River through the Uinta Mountains. Most rivers flow away from mountains, not toward them. But the Green, draining the mountains and plains of southern Wyoming, cuts sharply into the Uinta Mountains at the Wyoming-Utah State line, then flows $175 \mathrm{~km}$ east and south across the range through Utah and Colorado without regard for topographic relief or geologic structure. Why, at the Gates of Lodore, does the river turn south from the wide valley of Browns Park, where logical egress is eastward, reenter the mountains to the south, and for the next $80 \mathrm{~km}$ drain one canyon after another before reaching the Uinta Basin? The hypothesis I've advanced in earlier publications (Hansen, 1969a, p. 42-44, 58; 1969b; Hansen and others, 1982) is briefly recapitulated here:

The Green River was flowing southeast through the valley of Browns Park in middle Miocene time on a thickening fill (the Browns Park Formation) toward a possible junction with the Yampa River and ultimately, perhaps, the White River. The fill eventually overtopped the valley rim to the south, and the river, turning southward at the site of the present Lodore Canyon, found a new course across the Uinta Mountains toward the Uinta Basin. From the Gates of Lodore southward, the river established itself on the old upland surface of the Bishop Conglomerate, ultimately eroding its way down through the underlying rocks to the present canyon bottom. Then, as now, the Bishop Conglom- 
erate extended deep into the mountains as a network of coalesced alluvial fills (figs. 5, 8, 13, and 37). On the south slope of the range the Bishop is still so widely disposed along and near both rims of the canyon that there can be no doubt about the superposition of the river through it. Quite likely, a shallow south-flowing drainage had already been established over the site of Lodore Canyon on or through the Bishop Conglomerate at the time of spillover. If so, the Green simply took advantage of the already available course.

This concept calls for a much-thickened valley fill in Browns Park and for the subsequent removal of much of it by the Green River, but the evidence seem irrefutable. East of Lodore Canyon the Browns Park Formation still reaches altitudes comparable to the rims of the canyon, which are about $2,285-2,315 \mathrm{~m}$. The highest little-deformed remnant is at John Weller Mesa (shown on fig. 13), on the drainage divide between the Green River and the Little Snake River, $30 \mathrm{~km}$ southeast of the Gates of Lodore. There, the eroded top of the Browns Park Formation is about 2,195 $\mathrm{m}$ above sea level. John Weller Mesa slopes gently northeastward and probably has been gently tilted in that direction. Beds stratigraphically higher in the Browns Park Formation crop out to the northeast but, because of dip, at lower present altitudes. Twenty kilometers north of John Weller Mesa at Dry Mountain, remnants of the Browns Park Formation stand even higher-2,340 min an area that has been involved in strong late Tertiary warping. Their altitude may formerly have been higher than now.

In any event, a vast amount of material has been removed from the valley since the onset of canyon cutting. The highest part of John Weller Mesa is $540 \mathrm{~m}$ above the level of the Green River at the Gates of Lodore, a height only about $122 \mathrm{~m}$ lower than the canyon rim, or about 82 percent of the height of the canyon wall. A rough guess would place the volume of material removed from the old valley of Browns Park below the level of John Weller Mesa at $210 \mathrm{~km}^{3}$. (Here, the "old valley of Browns Park" is considered to be the area between the head of modern Browns Park, to the northwest in Utah, and Lone Mountain, to the southeast in Colorado-a total length of about $72 \mathrm{~km}$.) If the fill reached to the rim of Lodore Canyon, as postulated here, about $80 \mathrm{~km}^{3}$ of additional fill must have been removed. An even larger volume of Browns Park material has been eroded from areas to the east in Moffat County, and much more still remains.

The above hypothesis varies from views of earlier workers. Major Powell (1876), using the Uinta canyons as his type example, advanced the then-new concept of antecedence, which assumed erroneously that the Green River predated Laramide uplift of the Uinta Mountains and that as uplift progressed the river kept pace in eroding its canyons. Powell alluded to a stationary saw cutting a moving log: "the river was running ere the mountains were formed $* * *$ before the rocks were folded" (Powell, 1876, p. 152). Antecedence is an elegant concept, but cogent evidence rules it out for the Eastern Uinta Mountains, as S. F. Emmons (in Hague and Emmons, 1877, p. 194) was the first to point out.

Noting the abundance of high-level Tertiary deposits (Bishop) in the mountains, Emmons advocated superposition, a concept that nearly coincides with the view expressed here. Bradley (1936, p. 189) agreed that the Green was superimposed upstream and down from Lodore Canyon, but he doubted the supposed depth and extent of the old Tertiary fill and, elaborating on a suggestion of Sears (1924a), proposed instead that an ancestral east-flowing Green River was captured by a small but vigorous stream in Lodore Canyon, "Lodore Branch of Cascade Creek," and was thus diverted southward. (Cascade Creek is now Pot Creek.) This hypothesis disavows any extraordinary thickness of Browns Park fill and calls for headward erosion by "Lodore Branch," rather than a spillover by the Green, as postulated here. Bradley did not address the difficult problem as to how a small stream with a very small watershed in hard rock would erode across a divide to capture a much larger stream-a problem obviated by spillover. Hunt (1969, p. 90-99), in his brilliant analysis of the history of the Colorado River and its tributaries, proposed a compromise position between Powell and Emmons, a combination of antecedence and superposition, which he called "anteposition." Also questioning the extent of the fill, Hunt suggested that much of the depth of Lodore Canyon is an erosive response to renewed uplift of the range since the drainage was established. Hunt's surmise probably is true, but there is no known demonstrable evidence that the canyon area has been uplifted differentially relative to the valley of Browns Park in a way that would account for the depth of Lodore Canyon. The evidence suggests otherwise: The Green has eroded hundreds of meters downward in Browns Park also. The small difference in altitude owing to post-Bishop tilting between the head of Lodore Canyon and Browns Park is just a few meters per kilometer and, in that short a distance, is negligible compared to the depth of canyon erosion. Browns Park and Lodore Canyon are both parts of the same crustal block, and if renewed uplift has occurred, it probably was regionwide-epeirogenic_-and included Browns Park as well as Lodore Canyon. 


\section{YAMPA RIVER}

The physiographic evolution of the Yampa River in the Uinta region is more obscure than that of the Green, and its complete history may never be fully resolved. Some episodes in its development, however, are reasonably clear. Like the course of the Green River, the course of the Yampa through the Uinta Mountains is younger than the Bishop Conglomerate; the conglomerate is well preserved south of the Yampa River, and its transport direction was plainly from the north, from the crestal part of the range toward the flanks at right angles to the present course of the river. Neither the river nor the canyon could have existed at the time the Bishop was deposited. Upstream from the Uinta Mountains, however, before the main body of the Browns Park Formation was deposited, an ancestral stream-perhaps the Yampa-was delivering pebbly gravel from the Park Range to the basin in the LayMaybell area. This basin was formed after the deposition of the Bishop Conglomerate; tilted Bishop crops out on the distal side of the basin, dipping toward its source.

With the tectonic subsidence of the Eastern Uinta Mountains, the broad downwarp in the Lay-Maybell area became an accumulation basin for the dominantly lacustrine and eolian deposits of the Browns Park Formation. Fluvial deposits coarser than medium-grained sand are rare in the Browns Park of this area (Luft and Thoen, 1981), and currents were seldom strong enough to transport pebble-size debris (except at the onset of Browns Park deposition, when the basal conglomerate derived from the Park Range, described on previous pages, was laid down).

Through drainage, therefore, was weak during deposition of the main body of the Browns Park Formation. No outlet from the basin at that time has yet been identified, but trunk drainage probably skirted the north end of Cross Mountain, essentially along the present course of the Little Snake River between Cross Mountain and the easternmost Uintas. It then probably turned west along the present Yampa Canyon. (See discussion of Deerlodge monlocline, p. 53.) The Yampa River as such did not yet exist through Cross Mountain Canyon or Juniper Canyon, because both are superimposed canyons that postdate the deposition of the Browns Park Formation. In any event, drainage probably was overwhelmed by sediment. The abundance of eolian bedding in the Browns Park Formation in the Lay-Maybell area suggests aridity, and the meager runoff into the rather capacious basin may have been incapable of overtopping the basin rim. Basically, the Lay-Maybell area was an aggrading sink throughout Browns Park time. Dyni (1980) noted sandy calcitic concretions within the eolian sequence and thin horizontal beds of sandy limestone that he regarded as deposits of interdunal ponds. Continuing subsidence of the basin floor, moreover, may have prolonged its filling.

Downwarping of the magmitude indicated by the displacement of the Gilbert Peak erosion surface and the Bishop Conglomerate must have required a long period of time. Guided in part by faulting, the ensuing basin over the subsided Uinta arch was partly structural and partly erosional, and concomitant runoff from the higher mountains to the west must have followed available low ground and weakened rock. Erosional breaching of anticlines is common in a first cycle of erosion following uplift. A prominent set of joints parallel in trend with the axis of the Uinta anticline, moreover, suggests lateral extension normal to the axis. Such fracturing along the crest of the fold would abet breaching. Thus, the depositional basin in the Browns ParkLay syncline nearly coincides with the subsided Uinta arch and Axial Basin anticline. Inasmuch as the subsidence and valley cutting postdated the deposition of the Bishop Conglomerate and predated the deposition of the Browns Park Formation, a significant time break must have intervened between the deposition of the two formations. Radiometric dating indicates a break of perhaps $4 \mathrm{~m} . \mathrm{y}$. (See paragraph on age of the Browns Park Formation, p. 31.)

Meanwhile, drainage must have begun to develop along the present course of the Yampa River in Dinosaur National Monument soon after the Gilbert Peak surface was formed and the Bishop Conglomerate was deposited. That area is an asymmetrical, partly faulted structural trough between Douglas Mountain to the north and Blue Mountain to the south (Hansen and others, 1980, cross sections), and the early drainage should have been guided by the trough into a roughly east-west trend. The exact course is unclear; I view it as flowing west but extending itself east by headward erosion, possibly as far as the east boundary of the monument. Structurally, the trough is not nearly as deep as the Browns Park-Lay syncline, but it is deepest along its southern border next to the Yampa fault. Bishop Conglomerate is preserved at the east and west ends but not in the center; the Gilbert Peak erosion surface is sparingly preserved as accordant ridgelines and summits and, as noted previously, it slopes gently eastward and northward in response to post-Bishop tilting.

Thus, the westerly flow of the Yampa River in Dinosaur National Monument is against the direction of the present slope of the Gilbert Peak erosion surface. The rim at Harpers Corner, near the confluence with the Green, is more than $300 \mathrm{~m}$ higher than East Cactus Flat; westward drainage, therefore, must predate eastward tilting. Otherwise, the Yampa would have flowed east and would still do so. 
Before tilting, drainage wandered rather widely between Blue Mountain and Douglas Mountain, and in so doing, it planed off the smooth platform still well preserved $300 \mathrm{~m}$ or so above present drainage on East and West Cactus Flats (and less well preserved at Schoonover Pasture). This platform truncates bedding at an angle of $8^{\circ}-10^{\circ}$. The northerly component of tilt, then, would have encouraged the river to shift gradually northward, away from Blue Mountain and the Yampa fault and toward the flank of Douglas Mountain, where it is today.

The incised gooseneck meanders between Harding Hole and the Yampa's confluence with the Green at Echo Park may have formed as a hydraulic response to a rising base level induced by tilting up to the west and south against the direction of drainage. Canyon cutting followed, and it faithfully preserved the meander pattern. As entrenchment progressed, however, the meanders gradually shifted, undercutting the outsides of bends, slipping off the insides, and forming the dramatic overhangs for which the canyon is famous. The largest of these is more than a thousand feet high. Meander shifting was influenced by dip, inasmuch as most of the overhangs are on the downdip sides of meanders. The time of entrenchment can only be surmised, but downcutting would have been greatly enhanced by the spillover of the Green into Lodore Canyon and the resultant rejuvenation of the drainage system. Further entrenchment surely would have been enhanced by the postulated diversion of the Upper Green River near Green River, Wyo. (See next section.)

When drainage was flowing across East and West Cactus Flats, it also was flowing between Cross Mountain and the east end of the Uintas, now the valley of the Little Snake River. At that time it was cutting a broad terrace into the Bishop Conglomerate at Klauson Pasture (fig. 43) - present altitude about 1,980 m. This truncation predated the northerly tilt of the Eastern Uinta Mountains. Whether or not that stream should properly be called the Little Snake River is a moot question: It was the outlet for the growing playa or sedimentary basin in the Lay-Maybell area, it probably carried the overflow from the Browns Park area as well as the Little Snake and Yampa headwaters, and the Little Snake as now constituted did not yet exist. Drainage downstream along the present Yampa Canyon appears to be anteposed-established before

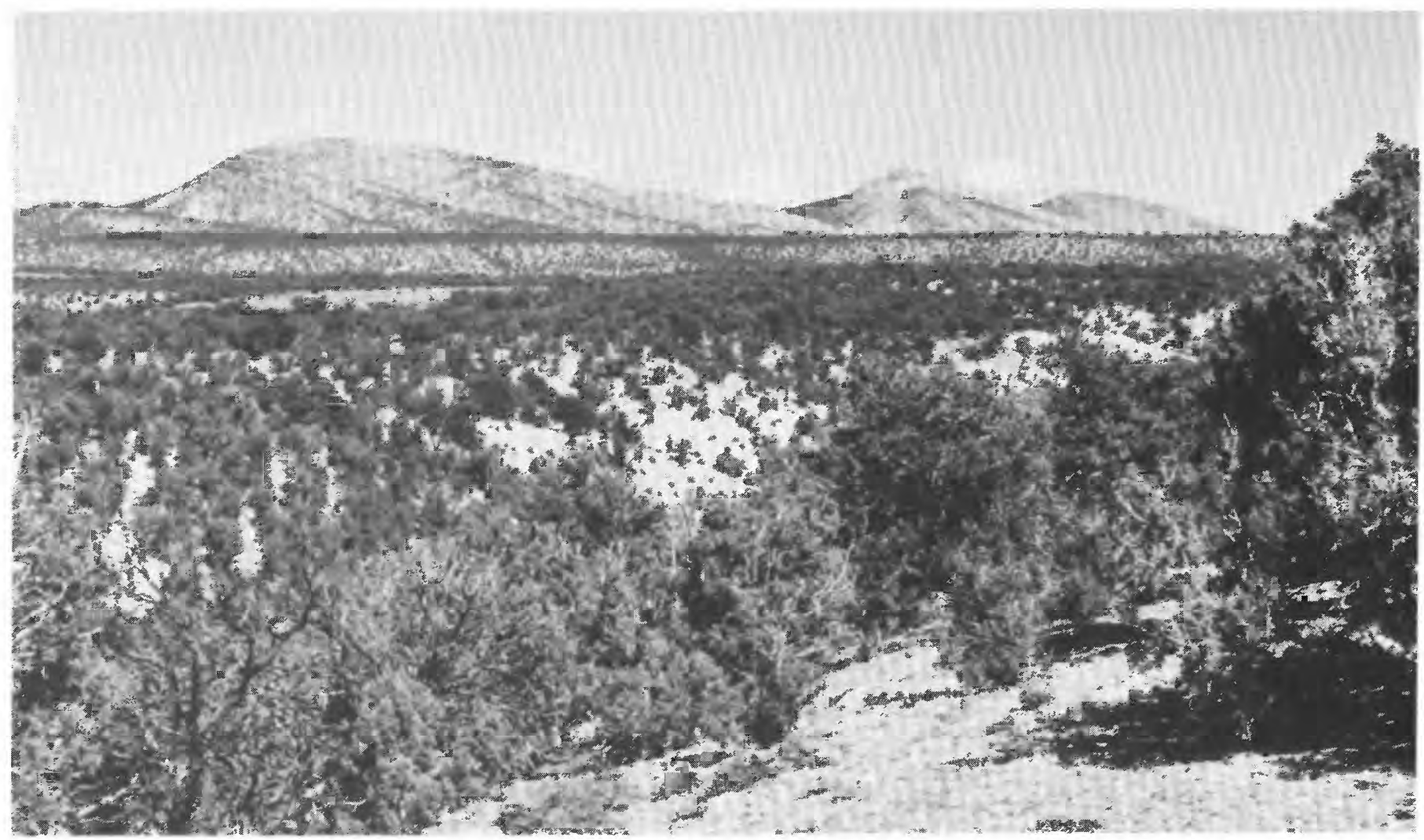

Figure 43.-View north toward Klauson Pasture (flat surface in distance at foot of easternmost Uinta Mountains), Moffat County, Colo. Klauson Pasture is capped by Bishop Conglomerate and has been terraced here by a second, lower erosion surface. Such incision of the Bishop Conglomerate is fairly common along the Uinta Mountains. Bradley (1936, p. 198) noted a similar incision of the Bishop Conglomerate on Cedar Mountain in Wyoming. 
tilting but maintained by entrenchment as tilting progressed and as aggradation upstream raised its bed on the thickening fill of the Lay-Maybell area.

The present course of the Yampa through Juniper Canyon and Cross Mountain Canyon did not exist until the end of Browns Park deposition (Hancock, 1915). Both canyons are accidents of superposition that formed after the level of fill had risen high enough to superimpose the drainage. Farther upstream, what is now the Yampa merely emptied into the playa and was lost in a sink of shifting sand. When the drainage changed from a depositional to an erosional mode, the Yampa became organized as a through-flowing river across the buried spurs of Cross and Juniper Mountains. This change may have been triggered by the diversion of the Green into Lodore Canyon.
Hunt (1969, p. 89) has suggested that Cross Mountain has risen $150 \mathrm{~m}$ since the superposition of the Yampa and, hence, that the lowest $150 \mathrm{~m}$ of canyon is due to antecedence after superposition (fig. 44). Such a rise should be expressed by upturning or faulting in the flanking Browns Park Formation. Exposures are inconclusive on the east side of Cross Mountain-upturning, if present, is minimal-and the Browns Park Formation is not preserved on the west, but just south of the Yampa River on the west side, the Bishop Conglomerate (Dyni's lower conglomerate unit of the Browns Park Formation) has been lowered as much as $150 \mathrm{~m}$ in a narrow graben along the Cross Mountain fault, well shown on Dyni's map (1968). The time of faulting is not precisely known, but Dyni (1980) noted post-Browns Park monoclinal folding and inferred

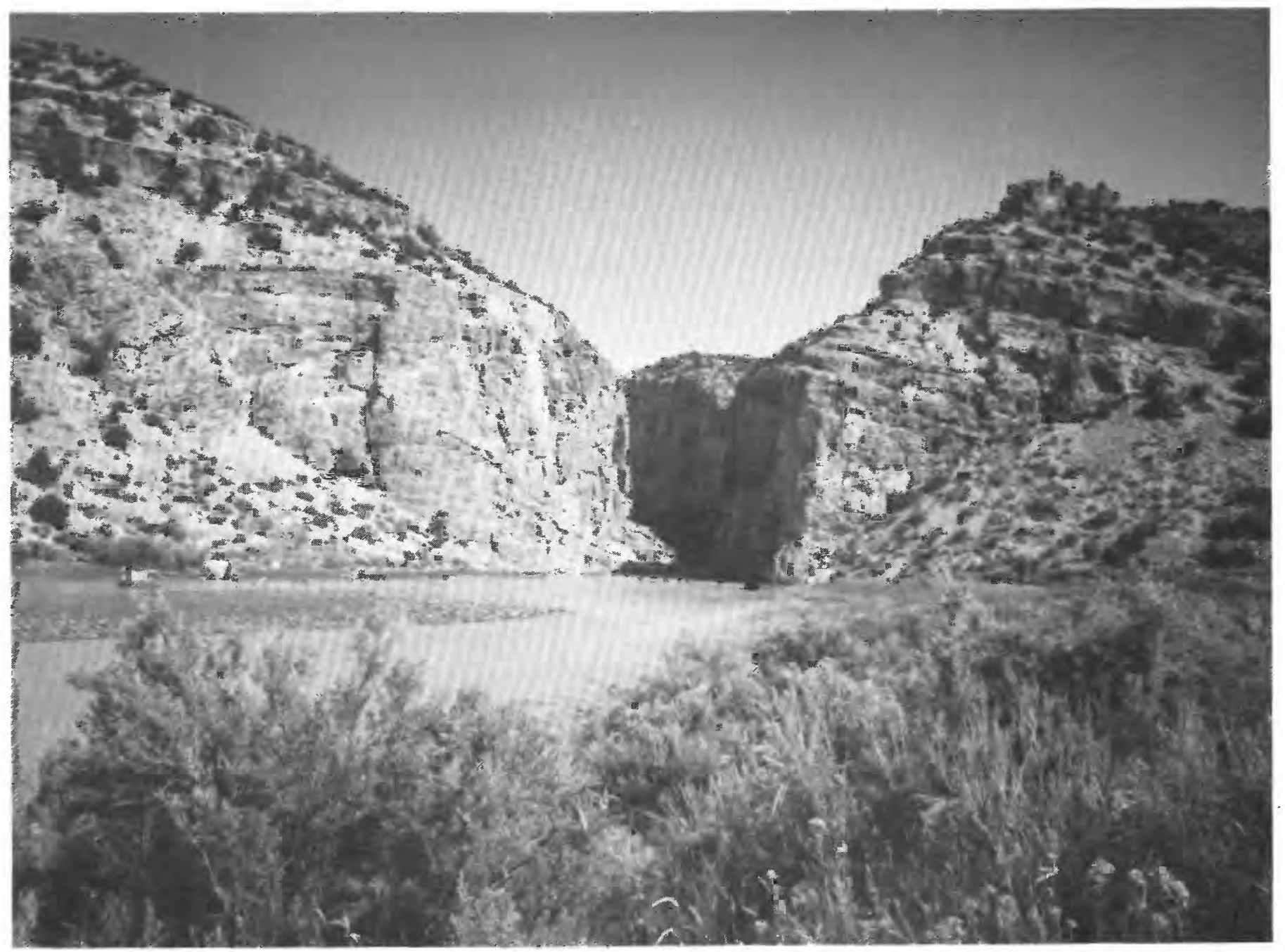

Figure 44.- Yampa River emerging from Cross Mountain Canyon, incised into the Madison Limestone. The course of the river here is superimposed, but Hunt (1969) has suggested that the full depth of the canyon in this view, about $150 \mathrm{~m}$, is antecedent to Pliocene-Pleistocene renewed uplift of Cross Mountain. The Cross Mountain fault at the base of the slope has had post-Bishop movement (Dyni, 1968). 
growth faulting in adjacent areas. Farther upstream, the rather tortuous meandering of the Yampa River above Juniper Canyon suggests that the river there has been base leveled by late resurgence of the Axial Basin anticline. These meanders are incised to a depth of about $150 \mathrm{~m}$.

Large horseshoe-shaped or amphitheatrical basins in the north wall of Yampa Canyon at various places are not "meander-migration scars" cut by the Yampa River at an early time, despite the belief of Sears (1962, p. 9 ), and they thus have no bearing on the development of canyon drainage. Rather, they are products of retrogressive landsliding down a dip slope (figs. 45 and 46). The hummocky but essentially translatory slides are restricted to places where the downcutting river has uncovered the incompetent lower member of the Morgan Formation dipping into the canyon. Failure within the Morgan removed support from the canyon walls above, and failure then retrogressed updip and radially outward from the points of origin. Subsequent gullying through some slides has exposed their rubbly interiors as well as the underlying Round Valley Limestone, which provides the resistant base of failure. The most accessible slide of this kind is not in Yampa Canyon but in Diamond Gulch along the road to Jones Hole, where ongoing failure is indicated by road damage, open ground cracks, and toppled blocks of sandstone tens of meters on a side.

\section{POSTULATED CAPTURE OF THE MASTER DRAINAGE OF THE GREEN RIVER BASIN}

The most significant major drainage change, in terms of the total budget of the streams involved, and probably also the most recent, was the postulated diversion of the Upper Green River ${ }^{3}$ from its ancestral easterly course. As a first step, by late Eocene or early Oligocene time, the Rock Springs uplift had been truncated by the Gilbert Peak erosion surface. Aspen Mountain remained as a monadnock, with a mantle of Bishop Conglomerate at its flanks. Drainage out of the Green River Basin was presumably eastward, across the present Continental Divide, for reasons discussed below.

As postulated previously (Hansen, 1969b, p. 99), the slow rise of the incipient Continental Divide in postBishop time stagnated easterly drainage. The Great Divide Basin rose so much in late Pliocene time that it was largely stripped of post-Eocene rocks (Love, 1971,

\footnotetext{
${ }^{3}$ As the following discussion postulates, the part of the Green River above the mouth of Bitter Creek, near the town of Green River, Wyo., was once a separate stream and has a significantly different history from the downstream reaches of the Green. For simplic ity and clarity, this part of the stream is here referred to as the "Upper Green River," even though, in more common usage, the Upper Green is regarded as the reach above the confluence of the Yampa River, the Green's chief tributary.
}

p. 79). As the eastern Uinta Mountains subsided, moreover, the new drainage along and across the range gradually extended its watershed, and the Upper Green River finally was captured near the present mouth of Bitter Creek at the town of Green River, Wyo. At that instant in geologic time the entire Green River system was turned south toward the Uinta Basin. Ritzma (1959, p. 88) has suggested that a rise of the Rock Springs uplift in Pliocene time and the extrusion of lavas over the north part of the uplift may have blocked easterly drainage. These lavas crop out in the Leucite Hills $30-45 \mathrm{~km}$ northeast of Rock Springs. They are now deeply dissected but were once more extensive, and they surely would have deflected any drainage in their path. Pilot Butte, $13 \mathrm{~km}$ northwest of Rock Springs, is an outlier, base altitude about $2,380 \mathrm{~m}$, resting on soft gray sandstone that resembles a fine facies of the Bishop Conglomerate. The base of the sandstone, altitude about $2,315 \mathrm{~m}$, rests on the Laney Member of the Green River Formation. Pilot Butte itself is about $520 \mathrm{~m}$ above the nearby Green River. The Leucite Hills lavas have been dated at about 1.25 m.y. (Bradley, 1964, p. A58) and more recently at $1.1 \mathrm{~m} . \mathrm{y}$. (McDowell, 1971). Their age, therefore, is compatable with Pleistocene diversion of the Upper Green River, but they seem too high and too old, as explained later, to have played a direct part. They could, however, have shifted drainage southward away from an earlier hypothetical course toward the Sweetwater River.

As a topographic feature, the present Continental Divide is very subdued all the way from the Wind River Range to the Sierra Madre. The divide splits and encircles the Great Divide Basin, which has interior drainage and contains many ill-defined watersheds and closed depressions, some of which contain playas. If the Great Divide Basin were filled to overflowing, it would spill to the North Platte River across a broad threshold about $2,000 \mathrm{~m}$ above sea level. The low point in the west rim of Great Divide Basin is just west of Tipton, Wyo., at an altitude of about $2,070 \mathrm{~m}$. This is the true position of the Continental Divide. It is about $245 \mathrm{~m}$ lower than the floor of the Gilbert Peak erosion surface near the center of the Green River Basin and about the same amount lower than the rims of Lodore Canyon at the Gates of Lodore. Just north of the Great Divide Basin the Sweetwater River, arising on the southwest side of the Wind River Range in an area that is structurally part of the Green River Basin, turns south, then east, and flows to the North Platte. Thus, even now, part of the drainage from the Green River Basin flows to the Gulf of Mexico, and has, according to Denson and Chisholm (1971, p. C125), since the end of the Eocene. 

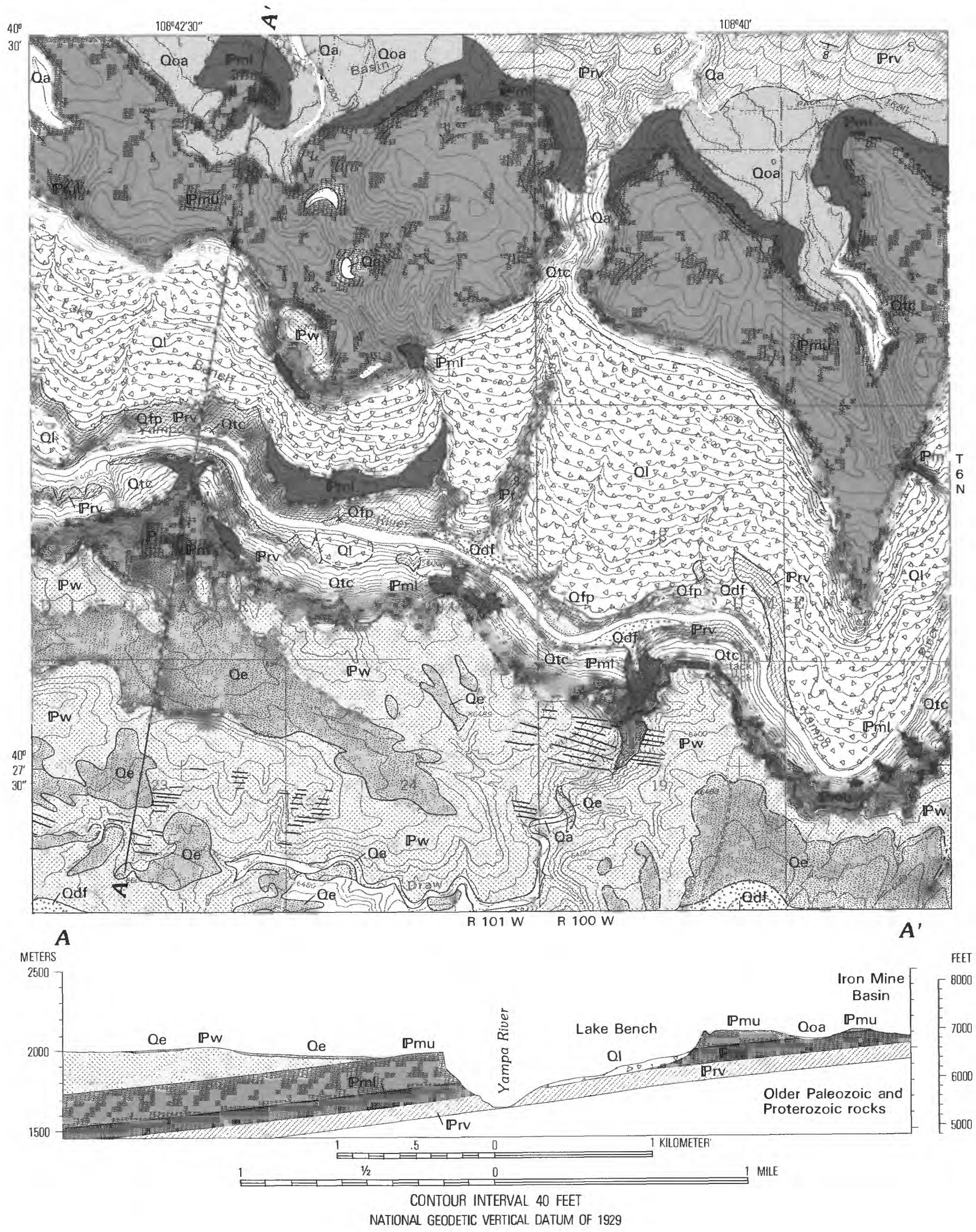
Once drainage turned across the Uinta Mountains at Lodore Canyon, and was thus flowing to the Uinta Basin, it was rapidly rejuvenated. The Uinta Basin is not only the deepest basin of the Colorado Plateau structurally (Hunt, 1956, p. 2), it is also some $300 \mathrm{~m}$ lower topographically than the Green River Basin. In late Pliocene time, as thus visualized, the main drainage of the Green River Basin (the Upper Green River) was still flowing eastward at a hydraulic disadvantage across the rising Rock Springs uplift and the rising incipient Continental Divide. The invigorated trans-Uinta drainage, however, with its new, lower base level, was incising itself into the Uinta Mountains, carving out the spectacular meander loops of Flaming Gorge, Horseshoe Canyon, and Red Canyon. Near Flaming Gorge it captured drainage that once flowed north into the Green River Basin, including Henrys Fork, Burnt Fork, and Birch Creek, as noted previously on page 59. These streams flow north off the Uinta Mountains, then turn southeast to join the Green. Other, lesser streams do the same (Hansen, 1965, p. 176). Some of the details can be gleaned from topographic maps of the area. Henrys Fork probably once flowed north through a gap between Hickey Mountain and Sage Creek Mountain ("Sage Creek Butte" in old reports;

\section{EXPLANATION}

\begin{tabular}{|c|c|}
\hline Qfp & $\begin{array}{l}\text { FLOODPLAIN AND CHANNEL DEPOSITS OF YAMPA } \\
\text { RIVER (HOLOCENE) }\end{array}$ \\
\hline De & EOLIAN SAND (HOLOCENE) \\
\hline Qdf: & DEBRIS FAN (HOLOCENE) \\
\hline Qa & ALLUVIUM IN VALLEY BOTTOMS (HOLOCENE) \\
\hline $\mathrm{OOI}_{\Delta}^{8} \mathrm{O}_{8}$ & LANDSLIDE DEPOSITS (HOLOCENE AND PLEISTOCENE) \\
\hline Qtc & $\begin{array}{l}\text { TALUS AND OTHER COLLUVIUM (HOLOCENE AND } \\
\text { PLEISTOCENE) }\end{array}$ \\
\hline Qoa & OLDER ALLUVIUM (PLEISTOCENE) \\
\hline Pw & WEBER SANDSTONE (MIDDLE PENNSYLVANIAN) \\
\hline Phit & $\begin{array}{l}\text { MORGAN FORMATION (MIDDLE PENNSYLVANIAN): } \\
\text { Upper member }\end{array}$ \\
\hline & Lower member \\
\hline$P$ Py? & $\begin{array}{l}\text { ROUND VALLEY LIMESTONE (LOWER PENNSYLVAN- } \\
\text { IAN) }\end{array}$ \\
\hline 9 & $\begin{array}{l}\text { CONTACT-Dashed where approximately located } \\
\text { STRIKE AND DIP OF BEDS }\end{array}$ \\
\hline & TRACE OF MASTER JOINTS \\
\hline
\end{tabular}

Figure 45 (on facing page).-Geologic map and section of part of the Haystack Rock quadrangle (Hansen and others, 1980) showing relationship of large, retrogressive landslides (Ql) in Yampa Canyon to amphitheatrical headwalls and to the incompetent lower member of the Morgan Formation.
Bradley, 1936, p. 199). Burnt Fork and Birch Creek, now flowing independently into Henrys Fork, may have merged and flowed north through a gravel-covered gap between Cedar Mountain and Black Mountain. Working headward against the prevailing regional slope, the expanding new river system then captured the Upper Green.

This capture may have been a middle Pleistocene event, although modern indigenous fish species in the Upper Green River drainage differ markedly from those in the North Platte and the Sweetwater. Only the mountain sucker and two closely related daces are common to the two drainage systems, according to $\mathrm{R}$. S. Behnke (Colorado State Univ., Dept. of Fisheries and Wildlife Biology, written commun., 1983). Any postulated connection, therefore, must take into account these differences.

The present Green River at Green River, Wyo., is flowing at an altitude of about $1,850 \mathrm{~m}$, only about 215 $\mathrm{m}$ lower than the Continental Divide at Tipton, $90 \mathrm{~km}$ to the east. Extending up the Green from a point a : few kilometers west of the town of Green River is a series of high gravel-capped terrace remnants. These remnants are about $120-180 \mathrm{~m}$ above modern drainage. Richmond (1948) correlated them with the Buffalo glaciation of the Wind River Range, though he later abandoned the name "Buffalo glaciation" because it represents three separate glaciations (Richmond, 1965, p. 218). The highest terrace, which will be mentioned further, is referred to as the "Peru bench" for its occurrence north of Peru station on the Union Pacific Railroad $10 \mathrm{~km}$ west of Green River (Hansen, 1969b, p. 99), where it has an altitude of about $2,040 \mathrm{~m}$ and is about $195 \mathrm{~m}$ above the river.

The gravel on the Peru bench contains an assortment of resistant rock types-particularly light-colored to



FIGURE 46.-Block diagram showing relationship of a retrogressive landslide to Yampa Canyon and the amphitheatrical form taken by the headwall scarp. Sliding begins when the lower member of the Morgan Formation is undercut by the river. Where such slides encroach on the river, they cause rapids. 
nearly black quartzite and pink granite-derived mainly from the Wind River and Wyoming Ranges, including many pebbles that may have been reworked out of the Pinyon Conglomerate and (or) Pass Peak Formation. It contains only subordinate amounts of red quartzite from the Uinta Mountains, because little Uinta Mountain drainage ever joined the Green River above that point. (Blacks Fork once joined the Green just above or about at the Peru bench and shared a common flood plain with the Green at that level.)

Significantly, the Peru bench does not extend downstream from Green River. However, a high gravel-capped bench $50 \mathrm{~km}$ east at the Rock Springs airport, referred to here as the "Rock Springs bench," may be its easterly correlative and may thus mark the former course of the Upper Green River, roughly along the present course of Bitter Creek, which now drains that area in the opposite direction. Other gravel benches stand at intermediate points between the Peru bench and the Rock Springs bench. The gravel on the Rock Springs bench is very similar to that on the Peru bench, although it is not as coarse and contains fewer granite pebbles and more red quartzite. Perhaps the granite was worn away by attrition in its transit downstream from the Peru bench area; the red quartzite may have been augmented by material carried out of the Uinta Mountains by Blacks Fork and by material reworked out of the Bishop Conglomerate south of Rock Springs.

The Rock Springs bench is about $130 \mathrm{~m}$ above the level of Bitter Creek. There is little likelihood, however, that its gravel was deposited by a diminutive stream like the present Bitter Creek, which is manifestly underfit (Drury, 1964) and carries no gravel. A local source for the gravel, moreover, is improbable, because the predominant rock types are derived from Precambrian sources and are much the same as the rocks in the Peru bench. No source for such rock types exists within the drainage basin of Bitter Creek. A more likely source, therefore, was the Upper Green River, before its diversion to the south.

The most easterly deposit carrying these clasts known to me is at Creston Junction, east of the Continental Divide on U.S. Interstate 80, about $130 \mathrm{~km}$ east of Rock Springs, Wyoming. This deposit overlies a bed of volcanic ash (Sanders, 1975) sampled by J. D. Love and identified by Izett and Wilcox (1982) as Lava Creek $\mathrm{B}$ ash from the Yellowstone caldera complex. The 0.62m.y. age of the Lava Creek B ash (Izett and Wilcox, 1982) indicates that the Upper Green River was still in its east-flowing course 600,000 years ago.

A continued late Tertiary and Quaternary uplift of the Continental Divide across southern Wyoming (Love, 1971, p. 79) probably was partly responsible for the Upper Green's capture and diversion. The gravel deposits rise toward the east, and their rise is a measure of the uplift of the Continental Divide. Thus, from a point near the town of Green River east to the Continental Divide near Creston, a distance of about $145 \mathrm{~km}$, the gravel deposit rises about $155 \mathrm{~m}$, at an average rate of about $0.94 \mathrm{~m} / \mathrm{km}$. Assuming that the gradient of the river was about the same before capture as now, about $0.9 \mathrm{~m} / \mathrm{km}$, the rise has been about $285 \mathrm{~m}$ in the 600,000 years since capture, or about $475 \mathrm{~mm}$ per thousand years. The tilting up toward the east has been about $1.84 \mathrm{~m} / \mathrm{km}$, or roughly $3.1 \mathrm{~mm} / \mathrm{km}$ per thousand years.

\section{RELATIONSHIP OF UPPER GREEN RIVER CAPTURE TO MODERN FISH FAUNAS}

Any hypothesis proposing that the Upper Green River was captured as recently as middle Pleistocene time must account for marked differences between the indigenous fish fauna of the present upper ColoradoGreen River drainage and that of the North Platte and its tributaries. A mixing of these faunas might be expected, but they are distinctly different. The Platte River is tributary to the large Mississippi-Missouri system and shares its faunal diversity, which includes many different families and species adapted to seasonally warm waters. It also includes a few cold-water taxa such as salmonids (trouts and whitefish) that are restricted to mountain headwaters in areas of geologically recent transfers across the Continental Divide from the Columbia River basin (Miller, 1958, 1965; Uyeno and Miller, 1963; Behnke and Benson, 1983). The North Platte, however, contains no native salmonids, for reasons mentioned below.

In contrast with the Missouri, the upper ColoradoGreen drainage has a narrowly limited fauna of only four families and 14 species adapted to two separate habitats: a lower altitude, seasonally warm-water habitat and a higher altitude, cold-water habitat. The warm-water species are endemic: that is, they are restricted to the Colorado drainage system and have evolved adaptations unique to that drainage, owing to long isolation from other river faunas (Behnke and Benson, 1983). These species are now greatly depleted in range and numbers, owing to habitat changes caused by river impoundments and irrigation, artificial population controls, and the introduction of highly competitive exotic species. Some of the endemic, warm-water species are endangered, such as the Colorado River squawfish (Ptychocheilus lucius), the humpback chub (Gila cypha), the bonytail chub (Gila elegans), and the razorback sucker (Xyrauchen texanus), which were abundant in the Green as far north as Green River, Wyo., before the construction of Flaming Gorge Dam (Behnke and Benson, 1983). They are adapted to tur- 
bid, seasonally warm water, and their former ranges were mostly restricted to the main stem of the Colorado River and the downstream reaches of its larger tributaries, such as the Green and the Yampa, where the water is suitably warm in summertime to sustain the habitat (Behnke and Benson, 1983).

Nonendemic fish native to the upper Colorado-Green drainage include cold-water, clear-water species transferred from the Columbia River basin in geologically recent time, such as the cutthroat trout (Salmo clarki), mountain whitefish (Prosopium williamsoni), speckled dace (Rhinichthys osculus yarrowi), and sculpins of the genus Cottus. None of these fish is indigenous to the North Platte drainage, although they thrive elsewhere in the headwaters of the Missouri River basin. All have close ties to the Columbia River basin.

A mountain sucker, Catostomus platyrhynchus, is native to both the Green and the North Platte drainage (R. J. Behnke, Colorado State University, Department of Fisheries and Wildlife Biology, written commun., 1983; Behnke and Benson, 1983) and poses a perplexing question, therefore, of interbasin fish dispersal. This fish also formerly lived in Picket Lake-a small lake without outlet in the Great Divide Basin-along with the lake chub, Couesius plumbia, which was native to the Sweetwater River but not the Green. Both species have been extirpated from Picket Lake by introduction of exotic species (G. T. Baxter, University of Wyoming, written commun., 1983).

Because of the marked differences in the native fish faunas of the Green and the North Platte, the Upper Green is postulated to have been captured at a time and under circumstances unfavorable to the interbasin transfer of fish populations. The least favorable time would have been at the height of a glacial stage, when the riverine environment was cold and hostile and the headwaters were locked in ice. At such a time the Green River Basin was a frigid semidesert, cold in summer and bitterly cold in winter. Widespread relict frost wedges, frost polygons, and remains of cold-climate terrestrial fauna suggest the existence of permafrost and a periglacial tundra throughout the intermontane basins of Wyoming during late Pleistocene time (Mears, 1981). Malde (1961) noted similar evidence in western Idaho and adjacent areas. Mears calculated that the average Wyoming temperature in late Wisconsin time was $10^{\circ}-13^{\circ} \mathrm{C}$ colder than now. Similar conditions probably prevailed during pre-Wisconsin glaciations.

The Green River Basin today remains one of the coldest areas of Wyoming, winter and summer (Lowers, 1978). Hardly in jest, the local people proclaim Big Piney, Wyo., the nation's icebox. The prediversion fish of the Green River Basin-linked to the North Platte and adapted to more moderate climates, thereforewould have been forced far downstream to warmer waters during the climatic deterioration of a glacial stage, leaving the basin void of fish life. East of Wyoming, the midcontinent was ice covered as far south as northeastern Nebraska during the Wisconsin stage, and even farther south during earlier glaciations (Flint, 1955, fig. 27; Mickelson and others, 1983).

Eroding northward from Flaming Gorge toward Green River, Wyo., the stream that captured the Upper Green River probably was ephemeral and contained no viable fish population. Inasmuch as its watershed was the dry, central part of the Green River Basin-even drier in late Wisconsin time than now (Gates, 1976)-it probably held little if any water except during prolonged wet periods or after heavy showers, when its flow would have been large and energetic. Moreover, because it was working headward through the saline Wilkins Peak Member of the Green River Formation, it would have contained high concentrations of alkaline salts. I, therefore, postulate a vigorous but ephemeral stream, devoid of fish life, capturing a much larger but also fish-free Upper Green River whose indigenous North Platte fish population had been forced far to the east, out of the Green River Basin, by the harsh Pleistocene climate and, perhaps, by the turbidity of the glacial meltwater. At that instant in geologic time, the entire drainage of the Upper Green was diverted south through the Uinta Mountains, and the diversion was without any transfer of fish populations. Then, with the warming of the interglacial climate, the endemic warm-water species of the Lower Green began to colonize the Green River Basin.

The native but nonendemic cold-water fishes of the headwaters and mountain tributaries of the ColoradoGreen River system-the cutthroat trout, mountain whitefish, speckled dace, mountain suckers, and sculpins-are all regarded as geologically recent entrants into the drainage system, inasmuch as they have evolved but little since their interbasin transfer (Behnke and Benson, 1983, p. 9). Because they are absent from the North Platte drainage (except the mountain sucker, Catostomus platyrhynchus), they must have migrated into the Green from the Columbia River basin by way of the Snake River, rather than by way of the Missouri, after the Upper Green was captured. Though absent from the North Platte, all these fish are native to the Upper Missouri; Marias Pass in northwestern Montana was an obvious transfer point across the Continental Divide, according to R. S. Behnke (written commun., 1983), until it was blocked by railroad construction early in the 20th century. The cutthroat trout, the species most adapted to cold water and least tolerant of warmth, never became established much below Great Falls, Mont. The whitefish reached the mouth of the Yellowstone but no farther down the Missouri, and the mountain sucker, the most warm- 
tolerant species, became widespread throughout the upper Missouri, including the Sweetwater (R. S. Behnke, written commun., 1983).

The mountain sucker may have entered the Platte drainage (the Sweetwater River) from the Wind River, according to G. T. Baxter of the University of Wyoming, Department of Zoology (written commun., 1983). If so, it should have transferred from the Columbia by way of the Flathead, the Missouri, and the Yellowstone. This fish tolerates the warm water of the Missouri and the lower Yellowstone, but the salmonids and sculpins do not, hence they were unable to reach the Sweetwater. The mountain sucker might also have traveled all the way down the Missouri to the mouth of the Platte, though the turbidity of the lower Platte would have been a deterrent to its further migration.

In any event, the cold-water fauna of the Green River must be high-altitude transfers from the Snake, since they are not natives of the Platte. The mountain sucker probably entered the Green along with the rest of the cold-water fauna, but being native to the Missouri and the Snake, as well as the Green, it theoretically could have made the transfer in either direction. The sucker family Catostomidae has a nearly continentwide Nearctic distribution, from Arctic Canada to Guatemala (Miller, 1958, fig. 10; Patterson, 1981, p. 274).

The time (or times) of fish transfer to the Green River is uncertain. At the time of any pre-late Wisconsin fish transfer, the topography of the interbasin divide would have been somewhat different from now, and possible transfer points accordingly would have been different also. A likely Holocene or very late Wisconsin transfer point is a broad, marshy morainal area straddling the Snake-Green divide in the extreme northwest corner of Sublette County, Wyo., drained by Raspberry Creek on the Snake River side and Wagon Creek on the Green River side (Mosquito Lake 71/2-minute quadrangle). The headwaters of these streams intermingle in a maze of ponds and bogs left behind by the withdrawal of the large late-Wisconsin (Pinedale) Green River glacier (G. M. Richmond, oral commun., 1984). Raspberry Creek is a first-order tributary of the Gros Ventre River, which in turn joins the Snake in Jackson Hole, Wyo. Wagon Creek flows directly to the Green. A few kilometers to the southwest, at another possible transfer point, Tepee Creek (Green River drainage) and Kinky Creek (Gros Ventre drainage) are separated by a chain of lakelets along another obscure divide in the same Pinedale moraine complex.

In one late Wisconsin transfer scenario, partial withdrawal of the Green River glacier from its terminus formed small proglacial lakes on the Wagon Creek side of the divide. These lakes then spilled north across the low divide into Raspberry Creek, allowing fish to mi- grate across to the Wagon Creek (Green River) side. When the ice melted back far enough to drain the lakes, the divide closed to further transmigration, and the fish moved into the Green River drainage. Whether or not a viable fish population could survive that close to the glacier terminus, however, is uncertain. The Colorado River subspecies of the cutthroat trout (Salmo clarki pleuriticus) requires a water temperature of about $7.2^{\circ} \mathrm{C}$ for spawning (Behnke and Benson, 1983, p. 29), and the meltwater temperature would have been close to freezing. Moreover, the turbidity of the meltwater would tend to bury and suffocate the eggs and suppress the growth of aquatic plants and small invertebrates needed to sustain a food chain. More likely, therefore, well after deglaciation, a physical connection through the bogs and ponds allowed fish to move freely from one drainage basin to the other. Such dual drainage is not uncommon in glaciated areas. Sedimentation in the ponds and gradual expansion of the bogs at the expense of the ponds eventually closed off the transfer routes.

Various low passes along the present Snake-Green River divide, including points along the headwaters of the Hoback River south of Jackson Hole, Wyo., suggest other possible earlier Pleistocene transfer points, some probably involving minor headwater stream captures. Transfers might have happened at more than one place and time. Twin Creek, near Kemmerer, Wyoming, is another early possibility, which could have linked the Bear River and Hams Fork of the Green River, at a time when Hams Fork was flowing at a terrace level about $100 \mathrm{~m}$ above present grade (Rubey and others, 1975). At that time the Bear must still have flowed into the Snake. Two Ocean Pass, on the Continental Divide just south of Yellowstone National Park, is a modern transfer point from the Snake to the upper Yellowstone River and perhaps also to the lower Yellowstone and the Missouri (Evermann, 1892, p. 28; Jordan and others, 1930), but the Upper and Lower Falls of the Yellowstone prevent counter migration from the Missouri to the Snake. Few fish, moreover, probably survive the descent of the Lower Falls, which plunge $94 \mathrm{~m}$ to a rocky bed.

Fish transfers from the Snake River to the Green most likely took place during one or more interglacial stages, inasmuch as the Snake-Green divide was partly ice clad during glacial maximums, as already noted, and the streams that remained open probably were heavily laden with sediment downstream from the glaciers. These fish prefer clear water and have low tolerance of turbidity. The subsequent dispersal of the cold-water fauna throughout the upper Colorado River basin, however, probably followed during a later glacial stage (Pinedale?), when the downstream water temperature throughout the basin was lowered enough to be toler- 

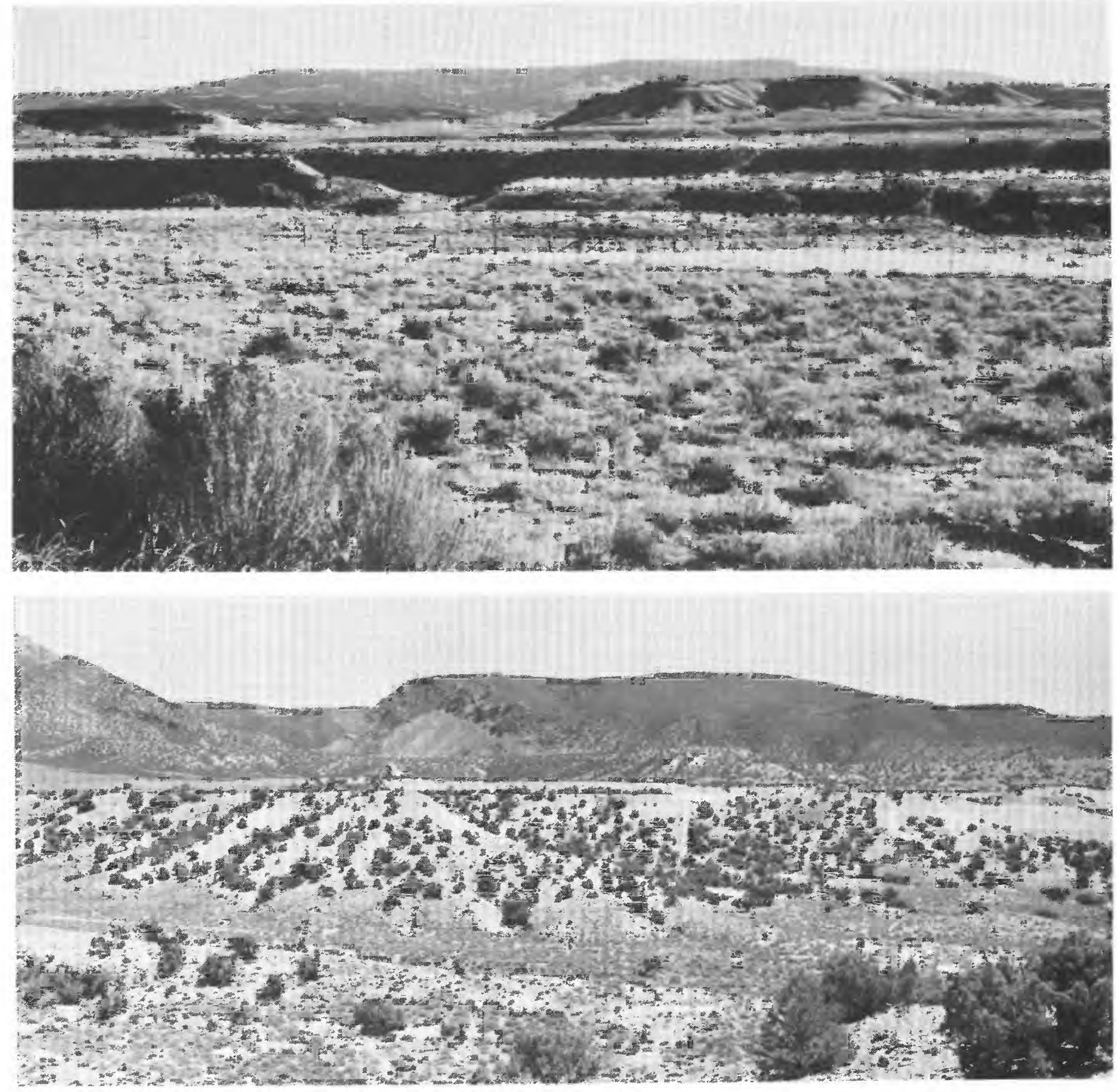

FiguRE 47.-Quaternary terraces in the Eastern Uinta Mountain area.

Top.-Quaternary terraces along Brush Creek northeast of Vernal, Utah. (See Kinney, 1955, p. 128). Remnant at upper right is about $120 \mathrm{~m}$ above Brush Creek. Diamond Mountain Plateau, on the skyline, is capped with Bishop Conglomerate more than $760 \mathrm{~m}$ above Brush Creek; its top appears uneven here only because the irregular rim of the plateau is viewed from below.

Bottom.-Gravel-capped Quaternary pediment remnants-rock fans-along northeast side of Browns Park at Utah-Colorado State line. Canyon of Beaver Creek, upper left. Cold Spring Mountain on the skyline. The highest Quaternary pediment remnant in the background is about $90 \mathrm{~m}$ above the level of Beaver Creek and about $150 \mathrm{~m}$ above the Green River, out of view at right (Hansen, 1965 , p. 132, plate 1).

ated. Meanwhile, the warm-water fauna would have been forced farther downstream. Then, as the water temperature slowly rose again during a succeeding interglacial, or the postglacial, the cold-water fauna would have abandoned the trunk drainages and moved gradually into the high-altitude, cold-water tributaries throughout the upper Colorado River basin. This event may have been Holocene. 


\section{QUATERNARY REENTRENCHMENT OF THE GREEN RIVER}

A postcript to the diversion of the Green River out of the Green River Basin and across the Uinta Mountains is the relatively brief history of the canyons since then. Field relations suggest reentrenchment of the Green River since the initial cutting of the canyons, especially of Lodore. Despite the steepness of the walls of Lodore Canyon, cross-canyon topographic profiles show a distinct slope break, steepening downward, about $245-300 \mathrm{~m}$ above the canyon floor (frontispiece). Profiles in Red Canyon are comparable to those in Lodore. The compound nature of the profile is most pronounced down spurs. Unrelated to lithology or stratigraphic shelving, the break in the profile is regarded as a result of accelerated downcutting and reentrenchment by the river, probably in early or middle Pleistocene time, after the canyon had been partly excavated (Hansen, 1969a, p. 48; Hansen and others, 1982). Thus, after Lodore Canyon had been eroded to a depth of about $460 \mathrm{~m}$, downcutting slowed and the river began to widen the valley bottom, but the river was then rejuvenated, and it cut down an additional $245 \mathrm{~m}$ or so to its present level. This figure is comparable to the amount of canyon deepening along the Colorado River in the Rocky Mountains in Quaternary time-230 m, according to Hunt (1969, p. 72).

Tributaries of Lodore Canyon responded to rejuvenation by renewed downcutting also, which led to breaks in their gradients at heights above the Green River in accordance with the breaks in the cross-canyon profiles (Hansen and others, 1982).

The cause and timing of renewed downcutting are uncertain. Regional uplift in response to unloading or some other factor would have rejuvenated the entire drainage system through the mountains. The capture of the Upper Green River could also have caused reentrenchment by greatly increasing the discharge and competence of the system. Capture and uplift may both have been involved. If initial cutting began in latest Miocene time after the Uinta Mountains were overtopped at Lodore Canyon, most of Pliocene time may have elapsed during the erosion of the upper $460 \mathrm{~m}$ of canyon. Reentrenchment, then, may have begun in early Pleistocene time.

The rate of canyon cutting can be inferred. If 760 $m$ is taken as the mean depth of Lodore Canyon and if cutting took all of Pliocene and Quaternary timeabout 5 million years - then the average rate was about $15 \mathrm{~cm}$ per thousand years. This rate compares favorably with that of the Black Canyon of the Gunnison River in central western Colorado, where the estimated rate was about $30 \mathrm{~cm}$ per thousand years (Hansen,
1965) but where the river, though smaller, has a much steeper gradient.

The actual cutting surely involved times of faster and slower erosion. Differential rates of Quaternary cutting are thus expressed by terracing upstream and downstream from the canyons. Terrace remnants are uncommon in the canyons but are abundant and well preserved in the softer rocks outside the mountains and in Browns Park (fig. 47). Climatic fluctuations contributed to Quaternary terracing, inasmuch as the terrace deposits correlate with episodes of mountain glaciation, but regional uplift must also have contributed to downcutting and terracing. The highest gravel-capped surfaces stand more than $150 \mathrm{~m}$ above river level, and downcutting of that magnitude can hardly be ascribed solely to climatic change. I favor the view that the terraces represent episodic aggradation in an otherwise degradational regime, when downcutting was temporarily overwhelmed by increased sedimentation.

\section{REFERENCES CITED}

Anderman, G. G., 1955, Tertiary deformational history of a portion of the north flank of the Uinta Mountains in the vicinity of Manila, Utah: Wyoming Geological Association Guidebook, 10th Annual Field Conference, Green River Basin, 1955, p. 130-134.

1961, Structure contour map of Colorado, in Berg, R. R., and Rold, J. W., eds., Symposium on Lower and Middle Paleozoic rocks of Colorado: Rocky Mountain Association of Geologists Guidebook, 12th Field Conference, p. 101-105.

Andersen, D. W., and Picard, M. D., 1972, Stratigraphy of the Duchesne River Formation (Eocene-Oligocene?), northern Uinta Basin, northeastern Utah: Utah Geological and Mineralogical Survey Bulletin 97, $29 \mathrm{p}$.

Armstrong, R. L., 1963, Age of intrusive rocks in the eastern Great Basin [abs.]: American Geophysical Union Transactions, v. 44, no. 1, p. 107.

1978, Cenozoic igneous history of the U.S. Cordillera from lat. $42^{\circ}$ to $49^{\circ}$ N., in Smith, R. B., and Eaton, G. P., eds., Cenozoic tectonics and regional geophysics of the Western Cordillera: Geological Society of America Memoir 152, p. 265-282.

Axelrod, D. I., 1981, Role of volcanism in climate and evolution: Geological Society of America Special Paper 185, $59 \mathrm{p}$.

Bagnold, R. A., 1954, Experiments on a gravity-free dispersion of large solid spheres in a Newtonian fluid under shear: Royal Society [London] Proceedings, v. 225, p. 49-63.

Bassett, W. A., Kerr, P. F., Schaeffer, O. A., and Stoenner, R. W., 1963, Potassium-argon dating of the late Tertiary volcanic rocks and mineralization of Marysvale, Utah: Geological Society of America Bulletin, v. 74, p. 213-220.

Behnke, R. J., and Benson, D. E., 1983, Endangered and threatened fishes of the upper Colorado River basin: Colorado State University Cooperative Extension Service Bulletin 503A, 38 p.

Behrendt, J. C., and Thiel, Edward, 1963, A gravity and magnetic survey of the Uinta Mountains: Journal of Geophysical Research, v. 68 , no. 3 , p. $857-868$.

Billingsley, Paul, 1933, Geologic structure and geologic history, in Boutwell, J. M., The Salt Lake region: International Geological Congress, 16th, United States, 1933, Guidebook 17, Excursion C-1, p. 19-24. 
Blackwelder, Eliot, 1915, Post-Cretaceous history of the mountains of central western Wyoming: Journal of Geology, v. 18, no. 3, p. 193-207.

Boutwell, J. M., 1912, Geology and ore deposits of the Park City district, Utah: U.S. Geological Survey Professional Paper 77, $231 \mathrm{p}$.

Boyer, B. W., 1982, Green River laminates-Does the playa-lake model really invalidate the stratified-lake model?: Geology, v. 10, p. 321-324.

Bradley, W. H., 1929, The varves and climate of the Green River epoch: U.S. Geological Survey Professional Paper 158-E, p. $87-110$.

1936, Geomorphology of the north flank of the Uinta Mountains: U.S. Geological Survey Professional Paper 185-I, p. 163-204.

1964 , Geology of Green River Formation and associated Eocene rocks in southwestern Wyoming and adjacent parts of Colorado and Utah: U.S. Geological Survey Professional Paper 496-A, 86 p.

-1973, Oil shale formed in desert environment-Green River Formation, Wyoming: Geological Society of America Bulletin, v. 84 , p. 1121-1124.

Bromfield, C. S., Erickson, A. J., Jr., Haddadin, M. A., and Mehnert, H. H., 1977, Potassium-argon ages of intrusion, extrusion, and associated ore deposits, Park City mining district, Utah: Economic Geology, v. 72, p. 837-848.

Bryant, Bruce, 1985, Structural ancestry of the Uinta Mountains, in, Picard, M. D., ed., Geology and energy resources, Uinta Basin of Utah: Utah Geological Association Publication 12, p. $115-120$.

Burke, D. B., and McKee, E. H., 1979, Mid-Cenozoic volcano-tectonic troughs in central Nevada: Geological Society of America Bulletin, pt. I, v. 90, p. 181-184.

Butler, B. S., Laughlin, G. F., and Heikes, V. C., 1920, The ore deposits of Utah: U.S. Geological Survey Professional Paper 111, $672 \mathrm{p}$.

Carey, B. D., Jr., 1959, Geology of the Rattlesnake Hills Tertiary volcanic field, Natrona County, Wyoming: Laramie, Wyo., University of Wyoming $\mathrm{Ph}$. D. thesis, $247 \mathrm{p}$.

Christiansen, R. L., and Lipman, P. W., 1972, Cenozoic volcanism and plate tectonic evolution of the western United States: Royal Society of London Philosophical Transactions, ser. A, v. 271, p. 249-284.

Christiansen, R. L., and McKee, E. H., 1978, Late Cenozoic volcanic and tectonic evolution of the Great Basin and Columbia intermontane regions, in Smith, R. B., and Eaton, G. P., eds., Cenozoic tectonics and regional geophysics of the Western Cordillera: Geological Society of America Memoir 152, p. 283-311.

Clement, J. H., 1977, Geological-geophysical illustrations of structural interpretations in Rocky Mountain basement tectonic terranes: American Association of Petroleum Geologists, Structural Geology School, Vail, Colo., lecture outline, illustrations, and references, July 11-15, 1977, 21 p.

Cook, K. L., Montgomery, J. R., Smith, J. T., and Gray, E. F., 1975, Simple Bouger gravity anomaly map of Utah: Utah Geological and Mineralogical Survey Map 37, scale 1:1,000,000

Crittenden, M. D., Jr., Sharp, B. J., and Calkins, F. C., 1952, Geology of the Wasatch Mountains east of Salt Lake City-Parleys Canyon to the Traverse Range: Utah Geological Society, Guidebook to the Geology of Utah, no. 8, p. 1-37.

Crittenden, M. D., Jr., Stuckless, J. S., Kistler, R. W., and Stern, T. W., 1973, Radiometric dating of intrusive rocks in the Cottonwood area, Utah: U.S. Geological Survey Journal of Research, v. 1 , no. 2 , p. $173-178$.
Cullins, H. L., 1969 [1970], Geologic map of the Mellen Hill quadrangle, Rio Blanco and Moffat Counties, Colorado: U.S. Geological Survey Geologic Quadrangle Map GQ-835, scale 1:24,000.

Damon, P. E., 1970, Correlation and chronology of ore deposits and volcanic rocks: Tucson, University of Arizona, U.S. Atomic Energy Commission Contract AT(11-1)-689, Annual Progress Report COO-689-130, $77 \mathrm{p}$.

Denson, N. M., and Chisholm, W. A., 1971, Summary of mineralogic and lithologic characteristics of Tertiary sedimentary rocks in the Middle Rocky Mountains and the northern Great Plains: U.S. Geological Survey Professional Paper 750-C, p. 117-126.

Desborough, G. A., 1978, A biogenic-chemical stratified lake model for the origin of oil shale of the Green River Formation-An alternative to the playa-lake model: Geological Society of America Bulletin, v. 89, p. 961-971.

Dorf, Erling, 1959, Climatic changes of the past and present: University of Michigan, Contributions from the Museum of Paleontology, v. 13, no. 8, p. 181-210.

Drury, G. H., 1964, Principles of underfit streams: U.S. Geological Survey Professional Paper 452-A, p. A1-A67.

Dyni, J. R., 1968, Geologic map of the Elk Springs quadrangle, Moffat County, Colorado: U.S. Geological Survey Geologic Quadrangle Map GQ-702, scale 1:62,500.

1980, Selected field notes and radiometric data on the Browns Park Formation in the Elk Springs quadrangle, Moffat County, Colorado: U.S. Geological Survey Open-File Report 80-526.

1981, Geology of the nahcolite deposits and associated oil shales of the Green River Formation in the Piceance Creek basin, Colorado: Boulder, Colo., University of Colorado Ph. D dissertation, $144 \mathrm{p}$.

Eardley, A. J., 1968, Major structures of the Rocky Mountains of Colorado and Utah, in A coast to coast tectonic study of the United States: UMR Journal, no. 1 (V. H. McNutt Colloquium, series 1), p. 79-99.

Ebens, R. J., 1963, Petrography of the Eocene Tower Sandstone lenses at Green River, Sweetwater County, Wyoming: Laramie, Wyo., University of Wyoming M.S. thesis, $46 \mathrm{p}$.

Emry, R. J., 1981, Additions to the mammalian fauna of the type Duchesnean, with comments on the status of the Duchesnean "age": Journal of Paleontlogy, v. 55, no. 3, p. 563-570.

Epis, R. C., and Chapin, C. E., 1975, Geomorphic and tectonic implications of the post-Laramide, late Eocene erosion surface in the Southern Rocky Mountains, in Curtis, Bruce, ed., Cenozoic history of the Southern Rocky Mountains: Geological Society of America Memoir 144, p. 45-74.

Epis, R. C., Scott, G. R., Taylor, R. B., and Chapin, C. E., 1980, Summary of Cenozoic geomorphic, volcanic and tectonic features of central Colorado and adjoining areas, in Kent, H. C., and Porter, K. W., eds., Colorado geology: Denver, Colo., Rocky Mountain Association of Geologists, p. 135-156.

Eugster, H. P., and Hardie, L. A., 1975, Sedimentation in an ancient playa-lake complex, the Wilkins Peak Member of the Green River Formation of Wyoming: Geological Society of America Bulletin, v. 86, p. 319-334.

Eugster, H. P., and Surdam, R. C., 1973, Depositional environment of the Green River Formation of Wyoming-A preliminary report: Geological Society of America Bulletin, v. 84, p. 1115-1120.

Evermann, B. W., 1892, A reconnaissance of the streams and lakes of western Montana and northwestern Wyoming: Bulletin U.S. Fisheries Commission, v. 11, p. 3-60.

Flint, R. F., 1955, Pleistocene geology of eastern South Dakota: U.S. Geological Survey Professional Paper 262, $173 \mathrm{p}$.

Gates, W. L., 1976, Modeling the Ice-age climate: Science, v. 191, p. 1138-1144. 
Gow, Kenneth, 1950, Douglas Creek gas field: Intermountain Association of Petroleum Geologists, Guidebook to the Geology of Utah, no. 5, p. 139-146.

Grande, Lance, 1980, Paleontology of the Green River Formation, with a review of the fish fauna: Geological Survey of Wyoming Bulletin 63, $333 \mathrm{p}$.

Gries, Robbie, 1981, Oil and gas prospecting beneath the Precambrian foreland thrust plates in the Rocky Mountains: The Mountain Geologist, v. 18 , no. 1, p. 1-18.

Hague, Arnold, and Emmons, S. F., 1877, Descriptive geology: U.S. Geological Exploration of the 40th Parallel (King), v. 2, 890 p.

Hamilton, Warren, 1981, Plate-tectonic mechanism of Laramide deformation, in Boyd, D. W., and Lillegraven, J. A., eds., Rocky Mountain foreland basement tectonics: University of Wyoming Contributions to Geology, v. 19, no. 2, p. 87-92.

Hancock, E. T., 1915, A history of a portion of Yampa River, Colorado, and its possible bearing on that of the Green River: U.S. Geological Survey Professional Paper 90-K, p. 183-189.

1925, Geology and coal resources of the Axial and Monument Butte quadrangles, Moffat County, Colorado: U.S. Geological Survey Bulletin 757, $134 \mathrm{p}$.

Hansen, W. R., 1957a, Geology of the Clay Basin quadrangle, Utah: U.S. Geological Survey Geologic Quadrangle Map GQ-101, scale 1:24,000.

-1957b, Structural features of the Uinta arch [Colorado-Utah], in Intermountain Association of Petroleum Geologists Guidebook, 8th Annual Field Conference, 1957: p. 48-52.

1965, Geology of the Flaming Gorge area, Utah-ColoradoWyoming: U.S. Geological Survey Professional Paper 490, $196 \mathrm{p}$.

1969a, The geologic story of the Uinta Mountains: U.S. Geological Survey Bulletin 1291, $144 \mathrm{p}$.

$1969 \mathrm{~b}$, Development of the Green River drainage system across the Uinta Mountains, in Geologic guidebook of the Uinta Mountains, Utah's maverick range: Intermountain Association of Geologists, 16th Annual Field Conference, p. 93-100.

-1977a, Geologic map of the Canyon of Lodore South quadrangle, Moffat County, Colorado: U.S. Geological Survey Geologic Quadrangle Map GQ-1403, scale 1:24,000.

$1977 \mathrm{~b}$, Geologic map of the Jones Hole quadrangle, Uinta County, Utah, and Moffat County, Colorado: U.S. Geological Survey Geologic Quadrangle Map GQ-1401, scale 1:24,000.

1984, Post-Laramide tectonic history of the Eastern Uinta Mountains, Utah, Colorado, and Wyoming: The Mountain Geologist, v. 21, p. 5-29.

Hansen, W. R., and Bonilla, M. G., 1954, Laramide faulting and orogeny on the north flank of the Uinta Mountains in eastern Daggett County, Utah: Colorado Scientific Society Proceedings, v. 17, no. 1, p. 1-29.

Hansen, W. R., and Carrara, P. E., 1980, Geologic map of the Tanks Peak quadrangle, Moffat County, Colorado: U.S. Geological Survey Geologic Quadrangle Map GQ-1534, scale 1:24,000.

Hansen, W. R., Carrara, P. E., and Rowley, P. D., 1980, Geologic map of the Haystack Rock quadrangle, Moffat County, Colorado: U.S. Geological Survey Geologic Quadrangle Map GQ-1535, scale $1: 24,000$.

1981, Geologic map of the Crouse Reservoir quadrangle, Uintah and Daggett Counties, Utah: U.S. Geological Survey Geologic Quadrangle Map GQ-1554, scale 1:24,000.

1982, Geologic map of the Canyon of Lodore North quadrangle, Moffat County, Colorado: U.S. Geological Survey Geologic Quadrangle Map GQ-1568, scale 1:24,000.
Hansen, W. R., Kinney, D. M., and Good, J. M., 1960, Distribution and physiographic significance of the Browns Park Formation, Flaming Gorge and Red Canyon areas, Utah-Colorado, in Short Papers in the geological sciences: U.S. Geological Survey Professional Paper 400-B, p. B257-B259.

Hansen, W. R., and Rowley, P. D., 1980a, Geologic map of the Hells Canyon quadrangle, Moffat County, Colorado: U.S. Geological Survey Geologic Quadrangle Map GQ-1536, scale 1:24,000.

1980b, Geologic map of the Stuntz Reservoir quadrangle, Utah-Colorado: U.S. Geological Survey Geologic Quadrangle Map GQ-1530, scale 1:24,000.

Hansen, W. R., Rowley, P. D., and Carrara, P. E., 1983, Geologic map of Dinosaur National Monument and vicinity, Utah and Colorado: U.S. Geological Survey Miscellaneous Investigations Map I-1407, scale 1:50,000.

Hintze, F. F., 1913, A contribution to the geology of the Wasatch Mountains, Utah: New York Academy of Science Annals, v. 23, p. 85-143.

Honey, J. G., and Izett, G. A., in press, Paleontology, taphonomy, and stratigraphy of the Browns Park Formation (Oligocene and Miocene) near Maybell, Moffat County, Colorado: U.S. Geological Survey Professional Paper 1358.

Hunt, C. B., 1956, Cenozoic geology of the Colorado Plateau: U.S. Geological Survey Professional Paper 279, $99 \mathrm{p}$.

1967, Physiography of the United States: San Francisco and London, W. H. Freeman, $480 \mathrm{p}$.

1969, Geologic history of the Colorado River: U.S. Geological Survey Professional Paper 669-C, p. 59-130.

1982, The anomalous transverse canyons of the Wasatch Range, in Nelson, D. L., ed., Overthrust belt of Utah: Utah Geological Association Publication 10, p. 81-89.

Hurich, C. A., and Smithson, S. B., 1982, Gravity interpretation of the southern Wind River Mountains, Wyoming: Geophysics, v. 47 , no. 11, p. 1550-1561.

Ingersoll, R. V., 1982, Triple-junction instability as cause for late Cenozoic extension and fragmentation of the western United States: Geology, v. 10, p. 621-624.

Izett, G. A., 1968, Geology of the Hot Sulphur Springs quadrangle, Grand County, Colorado: U.S. Geological Survey Professional Paper 586, $79 \mathrm{p}$.

1975, Late Cenozoic sedimentation and deformation in northern Colorado and adjoining areas, in Curtis, B. V., ed., Cenozoic history of the southern Rocky Mountains: Geological Society of America Memoir 144, p. 179-209.

Izett, G. A., Denson, N. M., and Obradovich, J. D., 1970, K-Ar ages of the lower part of the Browns Park Formation, northwestern Colorado, in Geological Survey research 1970: U.S. Geological Survey Professional Paper 700-C, p. C150-C152.

Izett, G. A., and Wilcox, R. E., 1982, Map showing localities and inferred distributions of the Huckleberry Ridge, Mesa Falls, and Lava Creek ash beds (Pearlette family ash beds) of Pliocene and Pleistocene age in the Western United States and Southern Canada: U.S. Geological Survey Miscellaneous Investigations Series Map I-1325.

Jordan, D. S., Evermann, B. W., and Howard, W. C., 1930, Check list of the fishes and fishlike vertebrates of North and Middle America north of the northern boundary of Venezuela and Colombia: Washington, U.S. Bureau of Fisheries, $670 \mathrm{p}$.

Keefer, W. R., 1970, Structural geology of the Wind River basin, Wyoming: U.S. Geological Survey Professional Paper 495-D, $35 \mathrm{p}$.

King, Clarence, 1878, Systematic geology: U.S. Geologic Exploration of the 40th Parallel (King), v. 1, 803 p., atlas. 
Kinney, D. M., 1955, Geology of the Uinta River-Brush Creek area, Duchesne and Uintah Counties, Utah: U.S. Geological Survey Bulletin 1007, $185 \mathrm{p}$.

Kinney, D. M., Hansen, W. R., and Good, J. M., 1959, Distribution of Browns Park Formation in eastern Uinta Mountains, northeastern Utah and northwestern Colorado [abs]: Geological Society of America Bulletin, v. 70, no. 12, pt. 2, p. 1630.

Laughlin, A. W., Lovering, T. S., and Mauger, R. L., 1969, Age of some Tertiary igneous rocks from the East Tintic district, Utah: Economic Geology, v. 64, p. 915-918.

Leopold, E. B., and MacGinitie, H. D., 1972, Development and affinities of Tertiary floras in the Rocky Mountains, in Graham, Alan, ed., Floristics and paleofloristics of Asia and eastern North America: Amsterdam, Elsevier Publishing Company, p. 147-200.

Lipman, P. W., Prostka, H. J., and Christiansen, R. L., 1972, Cenozoic volcanism and plate tectonic evolution of the western United States. I. Early and middle Cenozoic: Royal Society of London Philosophical Transactions, ser. A, v. 271, no. 1213, p. 217-248.

Love, J. D., 1960, Cenozoic sedimentation and crustal movement in Wyoming: American Journal of Science, v. 258 (Bradley Volume), p. 204-214.

1961, Definition of Green River, Great Divide, and Washakie basins, southwestern Wyoming: American Association of Petroleum Geologists Bulletin, v. 45, p. 1749-1755.

1970, Cenozoic geology of the Granite Mountains area, central Wyoming: U.S. Geological Survey Professional Paper 495-C, 154 p.

-1971, Relation of Cenozoic geologic events in the Granite Mountains area, central Wyoming, to economic deposits, in Symposium on Wyoming tectonics and their economic significance: Wyoming Geological Association Guidebook, 23rd Annual Field Conference, p. 71-80.

Lowers, A. R., 1978, Climate of Wyoming, in Climates of the States, v. 2, Nebraska-Wyoming: National Oceanic and Atmospheric Administration.

Luft, S. J., and Thoen, W. L., 1981, Measured sections of the Browns Park Formation (Miocene) in Moffat County, Colorado, 1980: U.S. Geological Survey Open-File Report 81-171, 37 p.

MacGinitie, H. D., 1969, Eocene Green River flora of northwestern Colorado and northeastern Utah: University of California Publications in Geological Sciences, v. 83, 203 p.

Malde, H. E., 1961, Patterned ground of possible solifluction origin at low-altitude in the western Snake River Plain, Idaho, in Short papers in the geologic and hydrologic sciences: U.S. Geological Survey Professional Paper 424-B, p. B170-B173.

Mauger, R. L., 1977, K-Ar ages of biotites from tuff in Eocene rocks of the Green River, Washakie, and Uinta basins, Utah, Wyoming, and Colorado: University of Wyoming Contributions to Geology, v. 15 , no. 1 , p. $17-41$.

Marvin, R. F., Byers, F. M., Jr., Mehnert, H. H., Orkild, P. P., and Stern, T. W., 1970, Radiometric ages and stratigraphic sequence of volcanic and plutonic rocks, southern Nye and western Lincoln Counties, Nevada: Geological Society of America Bulletin, v. 81 , p. $2657-2676$.

McDowell, F. W., 1971, K-Ar ages of igneous rocks from the western United States: Isochron/West, no. 2, p. 1-16.

McKay, E. J., 1974, Geologic map of the Lone Mountain quadrangle, Moffat County, Colorado: U.S. Geological Survey Geologic Quadrangle Map GQ-1144, scale 1:62,500.

McKay, E. J., and Bergin, M. J., 1974, Geologic map of the Maybell quadrangle, Moffat County, Colorado: U.S. Geological Survey Geologic Quadrangle Map GQ-1145, scale 1:62,500.
Mears, Brainerd, Jr., 1981, Periglacial wedges and the late Pleistocene environment of Wyoming's intermontane basins: Quaternary Research, v. 15, p. 171-198.

Mickelson, D. M., Clayton, Lee, Fullerton, D. S., and Borns, H. W., Jr., 1983, The late Wisconsin glacial record of the Laurentide ice sheet in the United States, in Porter, S. C., ed., The late Pleistocene, in the collection Late Quaternary environments of the United States: Minneapolis, University of Minnesota Press, p. 3-37.

Miller, R. R., 1958, Origin and affinities of the freshwater fish fauna of western North America, in Hubbs, C. L., ed., Zoogeography: American Association for the Advancement of Science Publication 51, p. 187-222.

1965, Quaternary freshwater fishes of North America, in Wright, H. E., and Frey, D. G., eds., The Quaternary of the United States-A review volume for the 7th Congress of the International Association for Quaternary Research: Princeton, N.J., Princeton University Press, p. 569-581.

Moore, W. J., and Lanphere, M. A., 1971, The age of porphyry-type copper mineralization in the Bingham district, Utah-A refined estimate: Economic Geology, v. 66, p. 331-334.

Moore, W. J., Lanphere, M. A., and Obradovich, J. D., 1968, Chronology of intrusion, volcanism, and ore deposition at Bingham, Utah: Economic Geology, v. 63, p. 612-621.

Naeser, C. W., Izett, G. A., and Obradovich, J. D., 1980, Fissiontrack and K-Ar ages of natural glasses: U.S. Geological Survey Bulletin 1489, $31 \mathrm{p}$.

Patterson, C., 1981, The development of the North American fish fauna; a problem of historical biogeography, in Forey, P. L., ed., The evolving biosphere: London, British Museum (Natural History) and Cambridge University Press, p. 265-281.

Powell, J. W., 1876, Report on the geology of the eastern portion of the Uinta Mountains and a region of country adjacent thereto: U.S. Geological and Geographical Survey of the Territories (Powell), 218 p.

Rich, J. L., 1910, The physiography of the Bishop Conglomerate, southwestern Wyoming: Journal of Geology, v. 18, no. 7, p. 601632.

Richmond, G. M., 1948, Modification of Blackwelder's sequence of Pleistocene glaciation in the Wind River Mountains, Wyoming [abs.]: Geological Society of America Bulletin, v. 59, no. 12, p. $1400-1401$.

-1965, Glaciation of the Rocky Mountains, in Wright, H. E., Jr., and Frey, D. G., ed., The Quaternary of the United States: Princeton, New Jersey, Princeton University Press, p. 217-230.

Ritzma, H. R., 1955, Early Cenozoic history of the Sand Wash basin, northwest Colorado, in Ritzma, H. R., and Oriel, S. S., eds., Guidebook to the geology of northwest Colorado: Intermountain Association of Geologists 6th Annual Field Conference and Rocky Mountain Association of Geologists Annual Field Conference, 1955 , p. 36-40.

1959, Geologic atlas of Utah, Daggett County: Utah Geological and Mineralogical Survey Bulletin 66, $111 \mathrm{p}$.

1965a, Fossil soil at base of Paleocene rocks, southern Rock Springs uplift, Wyoming, in Sedimentation of Late Cretaceous and Tertiary outcrops, Rock Springs uplift: Wyoming Geological Association Guidebook, 19th Field Conference, 1965, p. 136-139.

-1965b, Geologic significance, No. 1 Raeder-Government Dry Mountain anticline, Moffat County, Colorado, in Sedimentation of Late Cretaceous and Tertiary outcrops, Rock Springs uplift: Wyoming Geological Association Guidebook, 19th Field Conference, 1965, p. 131-135. 
1969, Tectonic resumé, Uinta Mountains, in Geologic guidebook of the Uinta Mountains, Utah's maverick range: Intermountain Association of Geologists, 16th Annual Field Conference, p. 57-63.

Roehler, H. W., 1961, The Late Cretaceous-Tertiary boundary in the Rock Springs uplift, Sweetwater County, Wyoming, in Symposium on Late Cretaceous rocks, Wyoming and adjacent areas: Wyoming Geological Association Guidebook, 16th Annual Field Conference, 1961, p. 96-100.

1965, Early Tertiary depositional environments in the Rock Springs uplift area, in Sedimentation of Late Cretaceous and Tertiary outcrops, Rock Springs uplift: Wyoming Geological Association Guidebook, 19th Annual Field Conference, 1965, p. $140-150$.

1972a, Geologic map of the Four J Rim quadrangle, Sweetwater County, Wyoming, and Moffat County, Colorado: U.S. Geological Survey Geologic Quadrangle Map GQ-1002, scale 1:24,000.

1972b, Geologic map of the Red Creek Ranch quadrangle, Wyoming, Utah, and Colorado: U.S. Geological Survey Geologic Quadrangle Map GQ-1001, scale 1:24,000.

1973, Stratigraphy of the Washakie Formation in the Washakie basin, Wyoming: U.S. Geological Survey Bulletin 1369, 40 p.

1974, Depositional environments of rocks in the Piceance Creek basin, Colorado, in Murray, D. K., ed., Energy resources of the Piceance Creek basin, Colorado: Rocky Mountain Association of Geologists Guidebook, 25th Field Conference, p. 57-64.

Rowley, P. D., Anderson, J. J., and Williams, P. L., 1975, A summary of Tertiary volcanic stratigraphy of the southwestern High Plateaus and adjacent Great Basin, Utah: U.S. Geological Survey Bulletin 1405-B, $20 \mathrm{p}$.

Rowley, P. D., Tweto, Ogden, Hansen, W. R., and Carrara, P. E., 1979 , Geologic Map of the Vernal $1^{\circ} \times 2^{\circ}$ quadrangle, Colorado, Utah, and Wyoming: U.S. Geological Survey Miscellaneous Field Studies Map MF-1163, scale 1:250,000.

Rubey, W. W., Oriel, S. S., and Tracey, J. I., Jr., 1975, Geology of the Sage and Kemmerer 15-minute quadrangles, Lincoln County, Wyoming: U.S. Geological Survey Professional Paper 855,18 p., map.

Ryder, R. T., Fouch, T. D., and Elison, J. H., 1976, Early Tertiary sedimentation in the western Uinta Basin, Utah: Geological Society of America Bulletin, v. 87, p. 496-512.

Sanders, R. B., 1975, Geologic map and coal resources of the Creston Junction quadrangle, Carbon and Sweetwater Counties, Wyoming: U.S. Geological Survey Coal Investigations Map C-73, scale $1: 24,000$.

Schultz, A. R., 1918, A geologic reconnaissance of the Uinta Mountains, northern Utah, with special reference to phosphate: U.S. Geological Survey Bulletin 690-C, p. 31-94.

1920, Oil possibilities in and around Baxter basin, in the Rock Springs uplift, Sweetwater County, Wyoming: U.S. Geological Survey Bulletin 702, $107 \mathrm{p}$.

Scott, K. M., and Gravlee, G. C., 1968, Flood surge on the Rubicon River, California-Hydrology, hydraulics, and boulder transport: U.S. Geological Survey Professional Paper 422-M, 40 p.

Sears, J. D., 1924a, Relation of the Browns Park Formation and the Bishop Conglomerate and their role in the origin of Green and Yampa Rivers: Geological Society of America Bulletin, v. 35 , p. 279-304.

1924b, Geology and oil and gas prospects of part of Moffat County, Colorado, and southern Sweetwater County Wyoming: U.S. Geological Survey Bulletin 751-G, p. 269-319.
1962, Yampa Canyon in the Uinta Mountains, Colorado: U.S. Geological Survey Professional Paper 374-I, 33 p.

Sears, J. D., and Bradley, W. H., 1925, Relations of the Wasatch and Green River Formations in northwestern Colorado and southern Wyoming: U.S. Geological Survey Professional Paper 132-F, p. 93-107.

Sears, J. W., Graff, P. J., and Holden, G. S., 1982, Tectonic evolution of lower Proterozoic rocks, Uinta Mountains, Utah and Colorado: Geological Society of America Bulletin, v. 93, p. 990-997.

Stanley, K. O., and Surdam, P. C., 1978, Sedimentation on the front of Eocene Gilbert-type deltas, Washakie Basin, Wyoming: Journal of Sedimentary Petrology, v. 48, p. 557-573.

Steel, R. J., Maehle, S., Nilsen, H., Røe, S. L., and Spinnangr, $\AA$., 1977, Coarsening-upward cycles in the alluvium of Hornelen Basin (Devonian) Norway-Sedimentary response to tectonic events: Geological Society of America Bulletin, v. 88, p. 1124 1134.

Steven, T. A., Cunningham, C. G., and Rowley, P. D., 1978, Geology and minerahization in the Marysvale mining area, west-central Utah, in Shawe, D. R., and Rowley, P. D., eds., Guidebook to mineral deposits of southwestern Utah: Utah Geological Association Publication 7, p. 67-70.

Stokes, W. L., 1976, What is the Wasatch line?: Rocky Mountain Association of Geologists, 1976, Symposium on the geology of the Cordilleran hingeline, p. 11-25.

Surdam, R. C., and Stanley, K. O., 1979, Lacustrine sedimentation during the culminating phase of Eocene Lake Gosiute, Wyoming (Green River Formation): Geological Society of America Bulletin, pt. I, v. 90, p. 93-110.

Surdam, R. C., and Wolfbauer, C. A., 1975, Green River Formation, Wyoming-A playa-lake complex: Geological Society of America Bulletin, v. 86, p. 335-345.

Tweto, Ogden, 1976, Geologic map of the Craig $1^{\circ} \times 2^{\circ}$ quadrangle, northwestern Colorado: U.S. Geological Survey Miscellaneous Investigations Series Map I-972, scale 1:250,000.

1979, Geologic map of Colorado: U.S. Geological Survey, scale $1: 500,000$.

Untermann, G. E., and Untermann, B. P., 1965, Geologic map of Dinosaur National Monument, Colorado-Utah: Vernal, Utah, Dinosaur Nature Association in cooperation with the Utah Geological and Mineralogical Survey and the Utah Field House of Natural History, scale 1:62,500.

Uyeno, Teruya, and Miller, R. R., 1963, Summary of late Cenozoic freshwater fish records for North America: University of Michigan, Occasional Papers of the Museum of Zoology, no. 63, p. 1-33.

Walton, P. T., 1944, Geology of the Cretaceous of the Uinta Basin, Utah: Geological Society of America Bulletin, v. 55, no. 1, p. 91-130.

Weber, J. R., 1971, Structural geology of the northeastern flank of the Uinta Mountains, Moffat County, Colorado: The Mountain Geologist, v. 8, p. 163-181.

Weiss, M. P., 1982, Relation of the Crazy Hollow Formation to the Green River Formation, central Utah, in Nelson, D. L., ed., Overthrust belt of Utah: Utah Geological Association Publication 10 , p. 285-289.

Wiegman, R. W., 1964, Late Cretaceous and early Tertiary stratigraphy of the Little Mountain area, Sweetwater County, Wyoming: Laramie, Wyo., University of Wyoming M.S. thesis, 53 p.

Winkler, G. R., 1970, Sedimentology and geomorphic significance of the Bishop Conglomerate and Browns Park Formation, eastern Uinta Mountains, Utah, Colorado, and Wyoming: Salt Lake City, University of Utah M.S. thesis, $115 p$. 